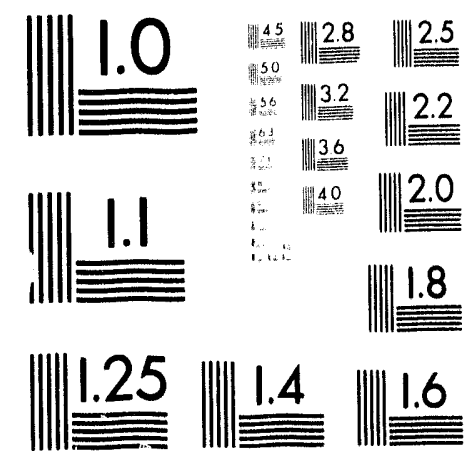



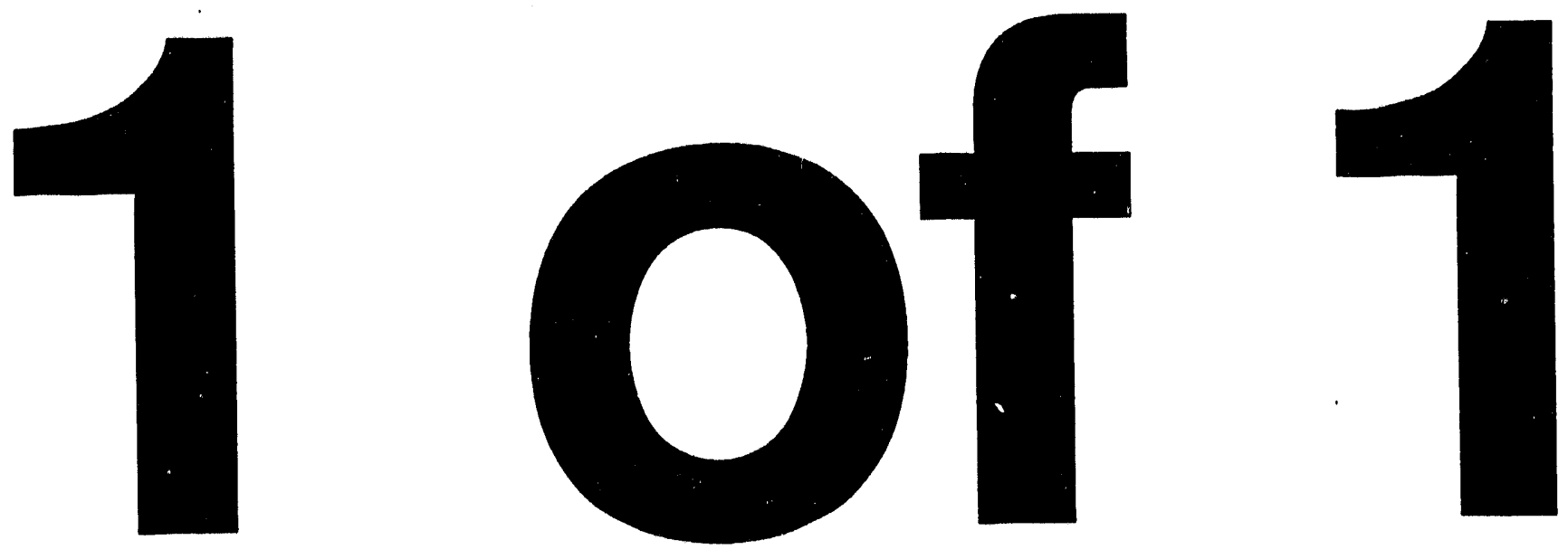


\section{EFFECT OF ALUMINUM AND SILCON REACTANTS AND PROCESS PARAMETERS ON GLASS-CERAMIC WASTE FORM CHARACTERISTICS FOR IMMOBILIZATION OF HIGH-LEVEL FLUORINEL-SODIUM CALCINED WASTE}

Krishna Vinjamuri

June 1993

W Westinghouse Idaho

PREPARED FOR THE

DEPARTMENT OF ENERGY

IDAHO OPERATIONS OFFICE

UNDER CONTRACT DE-AC07-84ID12435 


\section{ACKNOWLEDGMENTS}

The author wishes to thank D. V. Miley for SEM examination, Dr. S. V. Raman for microprobe examination and reviewing the report, Professor. David Howitt, University of California, Davis, for SEM and TEM examination, B. A. Staples and J. D. Herzog for reviewing the report, H. C. Wood for hot isostatic pressing of the waste formulations, R. P. Bopp for MCC-1 leach testing, and S. R. Mickelsen for formatting the draft report.. 


\section{TABLE OF CONTENTS}

ACKNOWLEDGMENTS $\ldots \ldots \ldots \ldots \ldots \ldots \ldots \ldots \ldots \ldots \ldots \ldots \ldots$

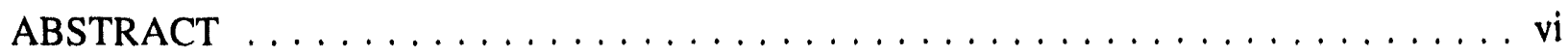

EXECUTIVE SUMMARY $\ldots \ldots \ldots \ldots \ldots \ldots \ldots \ldots \ldots$ viii

I. INTRODUCTION $\ldots \ldots \ldots \ldots \ldots \ldots \ldots \ldots \ldots \ldots \ldots \ldots \ldots \ldots \ldots \ldots \ldots$

II. EXPERIMENTAL PROCEDURE $\ldots \ldots \ldots \ldots \ldots \ldots \ldots \ldots \ldots \ldots \ldots$

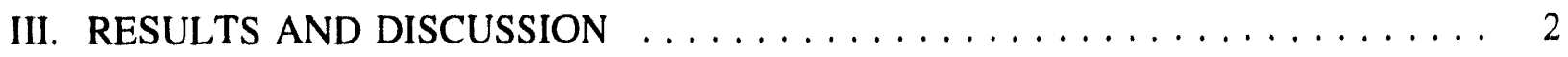

3.1 Compositions of the Calcine and the Glass-Ceramic Forms $\ldots \ldots \ldots \ldots 2$

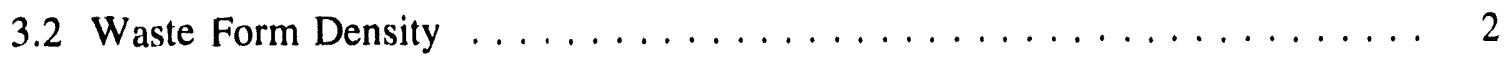

3.3 14-day MCC-1 Leach Rates ...................... 6

3.4 Glass Phase Composition $\ldots \ldots \ldots \ldots \ldots \ldots \ldots \ldots \ldots \ldots$

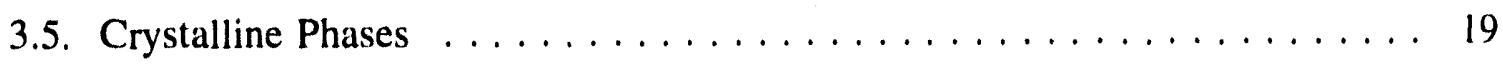

3.6. Microstructure ........................... 20

IV. SUMMARY AND CONCLUSIONS $\ldots \ldots \ldots \ldots \ldots \ldots \ldots \ldots \ldots \ldots \ldots, \ldots \ldots \ldots$

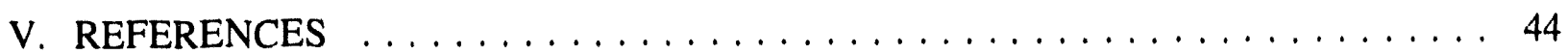

\section{FIGURES}

Figure 1. Total and normalized elemental leach rates for $\mathrm{Al}, \mathrm{B}, \mathrm{Ca}, \mathrm{Cd}$ and $\mathrm{Si}$ versus $\mathrm{Al}$ wt\% for waste forms with $0-6 \mathrm{wt} \% \mathrm{Al}$ and $0 \mathrm{wt} \% \mathrm{Si} \ldots \ldots \ldots \ldots \ldots$

Figure 2. Total and normalized elemental leach rates for $\mathrm{Cs}, \mathrm{K}, \mathrm{Na}$, and $\mathrm{Sr}$ versus $\mathrm{Al}$ wt\% for waste forms with $0-6 \mathrm{wt} \% \mathrm{Al}$ and $0 \mathrm{wt} \% \mathrm{Si} \ldots \ldots \ldots \ldots \ldots$ 
Figure 3. Total and normalized elemental leach rates versus $\mathrm{Si}$ wt\% for waste forms with $0-5$ $w t \% \mathrm{Si}$ and $2 \mathrm{wt} \% \mathrm{Al} \ldots \ldots \ldots \ldots \ldots \ldots$

Figure 4. Total and normalized elemental leach rates versus HIP soak time for 4-24 hr. waste forms with $2 \mathrm{wt} \% \mathrm{Al}$ and $0 \mathrm{wt} \% \mathrm{Si} \ldots \ldots \ldots \ldots \ldots$

Figure 5. Nonbridging oxygens vesrus $\mathrm{Al} w \mathrm{wt} \% \ldots \ldots \ldots \ldots \ldots$

Figure 6. Ternary phase diagram for $\mathrm{CaO}-\mathrm{Al}_{2} \mathrm{O}_{3}-\mathrm{SiO}_{2}$ system showing glass phase compositions for $0-6 \mathrm{wt} \% \mathrm{Al}$ glass-ceramic waste forms $\ldots \ldots \ldots \ldots \ldots \ldots$

Figure 7. Ternary phase diagram for $\mathrm{CaO}-\mathrm{Al}_{2} \mathrm{O}_{3}-\mathrm{SiO}_{2}$ system showing glass phase compositions for $0-5 \mathrm{wt} \%$ Si glass-ceramic waste forms $\ldots \ldots \ldots \ldots \ldots \ldots$

Figure 8. Ternary phase diagram for $\mathrm{CaO}-\mathrm{Al}_{2} \mathrm{O}_{3}-\mathrm{SiO}_{2}$ system showing glass phase compositions for $4-24$ hour glass-ceramic waste forms $\ldots \ldots \ldots \ldots \ldots \ldots$

Figure 9. SEM Micrographs at 200X for 0 $-6 \mathrm{wt} \%$ Al Glass-Ceramic Waste Forms . . . 22

Figure 10. SEM Micrographs at 500X for $0-6 \mathrm{wt} \%$ Al Glass-Ceramic Waste Forms . . 25

Figure 11. Micror robe Micrographs at 300X for 2 wt\% Al, 0-5 wt\% Si Glass-Ceramic Waste Forms $\ldots \ldots \ldots \ldots \ldots \ldots \ldots \ldots \ldots \ldots \ldots \ldots \ldots \ldots \ldots$

Figure 12. SEM/Probe Micrographs at 200-300X for 2 wt $\%$ Al Glass-Ceramic Waste Forms HIPed for 4-24 Hours.

Figure 13. SEM Micrographs at $200 \mathrm{X}$ for $2 \mathrm{wt} \%$ Al Glass-Ceramic Waste Forms Prepared with Ground and Unground Calcine. 
Figure 14. TEM Micrograph of Glass-Ceramic Waste Form Sample 48-2Al-0Si-4hr Showing a Zirconia Particle with the Characteristic Tetragonal/Cubic Layered Structure. . . . . . . 38

Figure 15. TEM Micrograph of Glass-Ceramic Waste Form Sample 48-2Al-0Si-4hr Showing a Chromium Needle in the Glass Phase. . . . . . . . . . . . . . . . . . . . . . 39

Figure 16. TEM Micrograph of Glass-Ceramic Waste Form Sample 48-2Al-0Si-4hr Showing a Cadmium Sulphide Particle in the Glass Phase. . . . . . . . . . . . . . . 40

Figure 17. TEM Micrograph of Glass-Ceramic Waste Form Sample 48-2Al-0Si-4hr Showing a Bright Field Image of Characteristic Mottling of Calcium Fluoride Phase. . . . . . . 4 41

\section{TABLES}

Table 1. Chemical Composition of a Non-Radioactive Simulated Fluorinel-Sodium Calcine 3

Table 2. Nominal Chemical Composition of Glass-Ceramic Waste Formulations in wt\%

Table 3. Density of Glass-Ceramic Waste Forms $\ldots \ldots \ldots \ldots \ldots \ldots \ldots$

Table 4. 14-day Total Mass Loss Rates (TMLRs) and Normalized Elemental Leach Rates in

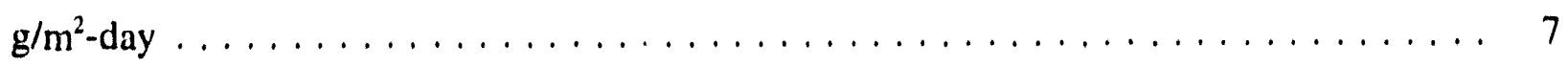

Table 5. 28-day Total Mass Loss Rates and Normalized Elemental Leach Rates in $\mathrm{g} / \mathrm{m}^{2}$-dayll

Table 6. Glass Phase Composition of Glass-Ceramic waste Forms (wt\%) $\ldots \ldots \ldots, 12$

Table 7. Glass Phase Composition in Compatibility Triangles $\ldots \ldots \ldots \ldots \ldots \ldots$ 
Table 8. Glass Phase Composition in Phase Compatibility Triangle ........... 19

Table 9. XRD Results for Crystalline Phases in Glass-Ceramic Waste Forms HIPed For 4-24

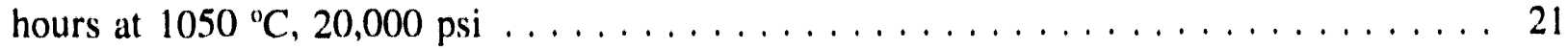




\begin{abstract}
In this report, the effects of aluminum and silicon reactants, process soak time and the initial calcine particle size on glass-ceramic waste form characteristics for immobilization of the high-level fluorinel-sodium calcined waste stored at the Idaho Chemical Processing Plant (ICPP) are investigated. The waste form characteristics include density, total and normalized elemental leach rates, and microstructure. Glass-ceramic waste forms were prepared by hot isostatically pressing (HIPing) a pre-compacted mixture of pilot plant fluorinel-sodium calcine, Al, and Si metal powders at $1050^{\circ} \mathrm{C}, 20,000$ psi for 4 hours. One of the formulations with 2 wt\% Al was HIPed for 4, 8, 16 and 24 hours at the same temperature and pressure. The calcine particle size range include as calcined particle size samaller than 600 $\mu \mathrm{m}$ (finer than -30 mesh, or $215 \mu \mathrm{m}$ Mass Median Diameter, MMD) and $180 \mu \mathrm{m}$ (finer than 80 mesh, or $49 \mu \mathrm{m}$ MMD).
\end{abstract}

The density of the waste forms increased as the aluminum additive increased, and there was no significant increase in density as the silicon content or the calcine particle size was increased. As the HIP time was increased from 4 to 24 hours for the 2 wt\% Al waste form, the density remained essentially constant suggesting that the waste form might have reached stable composition after about 4 hours of HIPing.

The 14-day MCC-1 total mass loss rates and normalized elemental leach rates for $\mathrm{Al}$, $\mathrm{B}, \mathrm{Ca}, \mathrm{Cd}, \mathrm{Cr}, \mathrm{Cs}, \mathrm{K}, \mathrm{Na}, \mathrm{Si}, \mathrm{Sr}$, and $\mathrm{Zr}$ are all less than $1 \mathrm{~g} / \mathrm{m}^{2}$-day for $2 \mathrm{wt} \% \mathrm{Al}(48-2 \mathrm{Al}$ $0 \mathrm{Si}-4 \mathrm{hr}$ ) and $3 \mathrm{wt} \% \mathrm{Si}$ (48-2Al-3Si-4hr) waste forms, and increased as the Al wt\% increased. The leach rates remained essentially constant for the 2 wt\% Al waste form that was HIPed for $4,8,16$ and 24 hours. However, the leach rates increased in the waste forms where the Si content was increased. Although the 14-day leach rates increased with increase in calcine particle size, these leach rates are all less than $1 \mathrm{~g} / \mathrm{m}^{2}$-day.

The major crystalline phases identified in all waste forms were zirconia, zircon and calcium fluoride. Albite was identified in 2 wi\% Al and 4, 8, 16 hour waste forms. 
Anorthite was indentified in 4 hour unground calcine $(-30$ mesh or $215 \mu \mathrm{m}$ MMD) and 16 and 24 hour ground calcine ( -80 mesh or $49 \mu \mathrm{m}$ MMD) waste forms.

Laboratory leach tests show that both the crystalline and glass phases are chemically durable in the $2 \mathrm{wt} \% \mathrm{Al}$ waste forms prepared with the particle sizes less than the initial calcine particle size of $215 \mu \mathrm{m}$ MMD (unground initial calcine particle size). No glass phase separation is apparent in the $2 \mathrm{wt} \% \mathrm{Al}$ waste form. It appears that the $2 \mathrm{wt} \% \mathrm{Al}$ waste form is a potential candidate for immobilization of the fluorinel-sodium calcine stored at the ICPP. 


\section{EXECUTIVE SUMMARY}

In this report, the effects of $\mathrm{Al}$ and $\mathrm{Si}$ reactants and the process parameters HIP soak time and the initial calcine particle size on fluorinel-sodium waste form characteristics, density, total and normalized elemental leach rates, and microstructure are investigated.

Series 48 formulation consisting of $70 \mathrm{wt} \%$ simulated fluorinel-sodium calcine, 28 $\mathrm{wt} \% \mathrm{SiO}_{2}$ and $2 \mathrm{wt} \% \mathrm{Al}$, was used for this study. Glass-ceramic waste forms were synthesized by HIPing a pre-compacted mixture of $70 \mathrm{wt} \%$ LTWM-1-90 unground fluorinelsodium calcine particle size of $600 \mu \mathrm{m}(-30$ mesh or $215 \mu \mathrm{m}$ mass median diameter, MMD), and ground calcine particle size of $180 \mu \mathrm{m}$ (-80 mesh or $49 \mu \mathrm{m}$ MMD), $0-6 \mathrm{wt} \% \mathrm{Al}, 0-5 \mathrm{wt} \%$ Si metal powders at 1050 " $\mathrm{C}, 20,000$ psi for 4 hours. The formulation with 2 wt\% Al was HIPed for $4,8,16$ and 24 hours at the same temperature and pressure.

The density of the waste forms increased from 3.03 to $3.10 \mathrm{~g} / \mathrm{cm}^{3}$ as the aluminum additive increased from 0-6 wt\%, and there was no significant increase in density as the silicon content was increased from $0105 \mathrm{wt} \%$ or the calcine particle size increased from 49 $\mu \mathrm{m}$ to $215 \mu \mathrm{m}$ MMD. As the HIP time was increased from 4 to 24 hours for the $2 w t \% \mathrm{Al}$ waste form, the density remained essentially constant suggesting that the waste form might have reached equilibrium composition at about 4 hours of HIPing.

The 14-day MCC-1 total mass loss rates (TMLR) and normalized elemental leach rates for $\mathrm{Al}, \mathrm{B}, \mathrm{Ca}, \mathrm{Cd}, \mathrm{Cr}, \mathrm{Cs}, \mathrm{K}, \mathrm{Na}, \mathrm{Si}, \mathrm{Sr}$ and $\mathrm{Zr}$ are all less than $1 \mathrm{~g} / \mathrm{m}^{2}$-day for $2 \mathrm{wt} \% \mathrm{Al}$ (48$2 \mathrm{Al}-0 \mathrm{Si}-4 \mathrm{hr})$ and $3 \mathrm{wt} \% \mathrm{Si}(48-2 \mathrm{Al}-3 \mathrm{Si}-4 \mathrm{hr})$ waste forms and the leach rates increased as the $\mathrm{Al}$ or the Si wt\% increased. The low leach rates for $2 \mathrm{wt} \% \mathrm{Al}$ and $3 \mathrm{wt} \%$ Si waste forms could be explained in terms of non-bridging oxygens per Al, Si tetrahedral network forming cation. The leach rates remained essentially constant for the 2 wt\% Al waste form that was HIPed for 4, 8, 16 and 24 hours. Although the leach rates increased with increase in calcine particle size, the leach rates are all less than $1 \mathrm{~g} / \mathrm{m}^{2}$-day. 
The ternary phase diagram for $\mathrm{CaO}-\mathrm{Al}_{2} \mathrm{O}_{3}-\mathrm{SiO}_{2}$ was used to interpret the glass phase composions. The composition of the waste form $0.6 \mathrm{wt} \%$ Al lie in the compatibility triangle for silica $\left(\mathrm{SiO}_{2}\right)$, alpha-wollastonite $\left(\mathrm{CaO} . \mathrm{SiO}_{2}\right)$ and anorthite $\left(\mathrm{CaO} . \mathrm{Al}_{2} \mathrm{O}_{3}, 2 \mathrm{SiO}_{2}\right)$ phasts. It appears that anorthite is a major component $(58 \mathrm{wt} \%)$ in the glass phase for 2 and $3 \mathrm{wt} \% \mathrm{Al}$ waste forms prepared by HIPing for 4 hours. Anorthite was not observed in 4 hours samples. However, anorthite was detected by XRD in 16 and 24 hour samples suggesting that the volume fraction that crystallized after 16-24 hours is significant for detection. However, the glass phase composition for the 4 hour waste form prepared with the unground calcine $(-30$ mesh or $215 \mu \mathrm{m}$ MMD) was at the stoichiometric composition of the anorthite phase.

X-ray diffraction (XRD) analysis identified zirconia, zircon and calcium fluoride as major crystalline phases in all the waste forms. Albite $\left(\mathrm{Na}_{2} \mathrm{O}-\mathrm{Al}_{2} \mathrm{O}_{3}-6 \mathrm{SiO}_{2}\right)$ was identified in 4, 8 and 16 hour waste form samples. Anorthite was indentified in 4 hour unground and 16 and 24 hour ground calcine waste forms. Metallic $\mathrm{Cd}$ and $\mathrm{CdS}$ phases were identified and the $\mathrm{Cd}$ leach rates were less than $1 \mathrm{~g} / \mathrm{m}^{2}$-day. None of the crystalline phases examined by SEM/EDS identified $\mathrm{Cr}$ containing crystals and the low $\mathrm{Cr}$ leach rates could be attributed to the durable glass phase.

The microstructures were examined using transmission electron microscopy (TEM) with the associated energy dispersive/wavelenth dispersive spectroscopy (EDS/WDS) and selected area diffraction. Microcrystallites of $\mathrm{Cr}, \mathrm{ZrO}_{2}$ and $\mathrm{CdS}$ were identified in the glass phase. No glass phase separation is apparent in the 2 wt\% Al waste form.

It appears that both the crystalline and glass phases are chemically durable in the 2 wt\% Al waste form prepared with the ground or unground calcine (49 or less than $215 \mu \mathrm{m}$ MMD). The measured elemental leach rates could be due to release from inter-phase houndaries, and any micro crystallites. It appears that the 2 wt\% Al waste form is a potential candidate for immobilization of the fluorinel-sodium calcine stored at the ICPP. 


\section{INTRODUCTION}

The high level liquid waste (HLLW) from nuclear fuel reprocessing has been calcined into solid granules and stored onsite at the Idaho Chemical Processing Plant (ICPP). Final disposal of the calcined waste in a geologic repository requires further consolidation of the calcine in to a solid waste form. One of the solid waste forms being considered for immobilization of the ICPP calcines is the glass-ceramic. The glass-ceramic waste form is a promising option because it can potentially reduce the calcined high level waste (HLW) volume signficantly compared to glass waste forms while maintaining similar leach rates. ${ }^{1.6}$ Based on technical evaluations, and laboratory and pilot plant mockup tests, the Environmental Protection Agency (EPA) believes that the glass-ceramic process is more efficient than the glass process for ICPP calcine waste forms'. The EPA has proposed that the glass-ceramic waste form technology is an acceptable technology to meet the Best Demonstrated Acceptable Technology (BDAT) for ICPP HLW calcine. In this report, the impact of aluminum and silicon reactant, HIP soak time and the initial calcine particle size on waste form density, leach rates, and microstructure of the glass-ceramic waste forms are discussed.

\section{EXPERIMENTAL PROCEDURE}

Glass-ceramic formulations were developed using the CERCOMP spread sheet computer program. ${ }^{k .9}$ Solid glass-ceramic waste forms were prepared by hot isostatic pressing (HIPing) of a pre-compacted mixture of the Formulation 48 that consists of $70 \mathrm{wt} \%$ sinulated fluorinel-sodium calcine of particle sizes smaller than the as calcined particle size of $600 \mu \mathrm{m}$ (215 $\mu \mathrm{m}$ Mass Median Diameter, MMD), 24-28 $\mathrm{wt}^{2} \mathrm{SiO}_{2}, 0-6 \mathrm{wt} \% \mathrm{Al}$ or 0-5 wt $\%$ Si metal powder at 1050 " $\mathrm{C}, 20,000 \mathrm{psi}$ for 4 hours. The formulation with 2 wt\% Al was HIPed for 424 hours. The waste forms were characterized for density, leach rates, glass and crystalline phases, and microstructure. Characterization techniques include density measurements using helium gas displacement Pycnometer, 14-day MCC-1 leach test" at 90 "C in deionized water, 
chemical analyses of leachates using inductively coupled plasma (ICP)

and atomic emission (AES) spectroscopy, electron microprobe analysis, SEM analysis with the associated energy dispersive and wavelength dispersive spectrometers (EDS and WDS) for glass phase composition and transmission electron microscopy (TEM) for microcystalline phases. These techniques are described in previous progress reports and technical papers. ${ }^{4.5}$

\section{RESULTS AND DISCUSSION}

In this section the results of calcine and waste form compositions, and the effects of aluminum and silicon reactants, the HIP soak time and the initial calcine particle size on density, leach rates, and phase composition are discussed.

\subsection{Compositions of the Calcine and the Glass-Ceramic Forms}

The chemical composition of the simulated fluorinel-sodium calcine (LTWM-1-90) and the formulations used for this study are presented in Tables 1 and 2 , respectively. The simulated fluorinel-sodium calcine consists of the glass modifiers $\mathrm{Na}_{2} \mathrm{O}, \mathrm{K}_{2} \mathrm{O}, \mathrm{CaO}, \mathrm{SrO}$, and C.dO, intermediates $\mathrm{Al}_{2} \mathrm{O}_{3}, \mathrm{ZrO}_{2}$ and the refractory components $\mathrm{CaF}_{2}$ and $\mathrm{Cr}_{2} \mathrm{O}_{3}$. The two major components, $\mathrm{B}_{2} \mathrm{O}_{3}$ and $\mathrm{Al}_{2} \mathrm{O}_{3}$ are generally known to show a dual behavior as glass formers or modifiers in $\mathrm{SiO}_{2}$ glasses. To transform the calcine into glass phase, $\mathrm{SiO}_{2}$ was added to the calcine. Aluminum or silicon metal powders were also added to reduce some of the oxides to metals (for example to reduce $\mathrm{CdO}$ to $\mathrm{Cd}$ ) and also to provide a localized internal heat source due to the heat of reaction during conversion to alumina and/or silica.

\subsection{Waste Form Density}

The densities of the waste forms are given in Table 3. The waste form density increased from 3.03 to $3.10 \mathrm{~g} / \mathrm{cm}^{3}$ as the aluminum additive increased, due to increase in alumina content in the glass phase. However, there was no significant increase in density as silicon was increased from 3-5 wt \%. As the HIP time was increased from 4 to 24 hours for 
Table 1

Chemical Composition of a Non-Radioactive Simulated Fluorinel-Sodium Calcine

\begin{tabular}{|c|c|}
\hline Component & $\begin{array}{c}\text { Simulated } \\
\text { Calcine }(w t \%)^{n}\end{array}$ \\
\hline $\mathrm{Al}_{2} \mathrm{O}_{3}$ & 8.3 \\
\hline $\mathrm{B}_{2} \mathrm{O}_{3}$ & 4.4 \\
\hline $\mathrm{CaO}$ & 11.5 \\
\hline $\mathrm{CaF}_{2}$ & 35.1 \\
\hline $\mathrm{CdO}$ & 3.9 \\
\hline $\mathrm{CeO}_{2}$ & 1.1 \\
\hline $\mathrm{Cl}^{1-}$ & 0.2 \\
\hline $\mathrm{Cr}_{2} \mathrm{O}_{3}$ & 1.2 \\
\hline $\mathrm{Cs}_{2} \mathrm{O}$ & 0.1 \\
\hline $\mathrm{Fe}_{2} \mathrm{O}_{3}$ & 0.3 \\
\hline $\mathrm{K}_{2} \mathrm{O}$ & 1.7 \\
\hline $\mathrm{Na}_{2} \mathrm{O}$ & 5.3 \\
\hline $\mathrm{SrO}$ & 0.6 \\
\hline $\mathrm{SeO}$ & 0.2 \\
\hline $\mathrm{ZrO}_{2}$ & 16.9 \\
\hline $\mathrm{PO}_{4}^{3-}$ & 0.2 \\
\hline Misc. & 9.0 \\
\hline Total & 100.00 \\
\hline
\end{tabular}

"- based on elemental analysis and oxide calculation of mixed ground calcine. 
Table 2

Nominal Chemical Composition of Glass-Ceramic Waste Formulations in wt\%

\begin{tabular}{||l|l|l|l|l|l||}
\hline Waste Form & Calcine & Silica & Aluminum & Silicon & Total \\
\hline $48-0 \mathrm{Al}-0 \mathrm{Si}-4 \mathrm{hr}$ & 70.0 & 30.0 & 0.0 & 0.0 & 100.0 \\
\hline $48-2 \mathrm{Al}-0 \mathrm{Si}-4 \mathrm{hr}$ & 70.0 & 28.0 & 2.0 & 0.0 & 100.0 \\
\hline $48-3 \mathrm{Al}-0 \mathrm{Si}-4 \mathrm{hr}$ & 70.0 & 27.0 & 3.0 & 0.0 & 100.0 \\
\hline $48-4 \mathrm{Al}-0 \mathrm{Si}-4 \mathrm{hr}$ & 70.0 & 26.0 & 4.0 & 0.0 & 100.0 \\
\hline $48-5 \mathrm{Al}-0 \mathrm{Si}-4 \mathrm{hr}$ & 70.0 & 25.0 & 5.0 & 0.0 & 100.0 \\
\hline $48-6 \mathrm{Al}-0 \mathrm{Si}-4 \mathrm{hr}$ & 70.0 & 24.0 & 6.0 & 0.0 & 100.0 \\
\hline $48-2 \mathrm{Al}-3 \mathrm{Si}-4 \mathrm{hr}$ & 70.0 & 25.0 & 2.0 & 3.0 & 100.0 \\
\hline $48-2 \mathrm{Al}-4 \mathrm{Si}-4 \mathrm{hr}$ & 70.0 & 24.0 & 2.0 & 4.0 & 100.0 \\
\hline $48-2 \mathrm{Al}-5 \mathrm{Si}-4 \mathrm{hr}$ & 70.0 & 23.0 & 2.0 & 5.0 & 100.0 \\
\hline
\end{tabular}

${ }^{\mathrm{b}}$ The waste forms are identified as the Series $48, \mathrm{Al}$ wt $\%, \mathrm{Si}$ wt $\%$ and the HIP soak time in hours. 
Table 3

Density of Glass-Ceramic Waste Forms

\begin{tabular}{||l|l|l|l||}
\hline Waste Form & $\begin{array}{l}\text { HIP Time } \\
\text { (hours) }\end{array}$ & $\begin{array}{l}\text { Calcine Particle Size, } \\
\text { mesh (MMD in } \mu \mathrm{m})\end{array}$ & $\begin{array}{l}\text { Density } \\
(\mathrm{g} / \mathrm{cc})\end{array}$ \\
\hline $48-0 \mathrm{Al}-0 \mathrm{Si}-4 \mathrm{hr}$ & 4 & $-80(49)$ & 3.0585 \\
\hline $48-2 \mathrm{Al}-0 \mathrm{Si}-4 \mathrm{hr}$ & 4 & $-80(49)$ & 3.0335 \\
\hline $48-3 \mathrm{Al}-0 \mathrm{Si}-4 \mathrm{hr}$ & 4 & $-80(49)$ & 3.0430 \\
\hline $48-4 \mathrm{Al}-0 \mathrm{Si}-4 \mathrm{hr}$ & 4 & $-80(49)$ & 3.0861 \\
\hline $48-5 \mathrm{Al}-0 \mathrm{Si}-4 \mathrm{hr}$ & 4 & $-80(49)$ & 3.1039 \\
\hline $48-2 \mathrm{Al}-3 \mathrm{Si}-4 \mathrm{hr}$ & 4 & $-80(49)$ & 3.0404 \\
\hline $48-2 \mathrm{Al}-4 \mathrm{Si}-4 \mathrm{hr}$ & 4 & $-80(49)$ & 3.0303 \\
\hline $48-2 \mathrm{Al}-5 \mathrm{Si}-4 \mathrm{hr}$ & 4 & $-80(49)$ & 3.0512 \\
\hline $48-2 \mathrm{Al}-0 \mathrm{Si}-4 \mathrm{hr}$ & 8 & $-80(49)$ & 3.0412 \\
\hline $48-2 \mathrm{Al}-0 \mathrm{Si}-4 \mathrm{hr}$ & 16 & $-80(49)$ & 3.0392 \\
\hline $48-2 \mathrm{Al}-0 \mathrm{Si}-4 \mathrm{hr}$ & 24 & $-80(49)$ & 3.0405 \\
\hline $48-2 \mathrm{Al}-0 \mathrm{Si}-4 \mathrm{hr}-49^{\mathrm{c}}$ & 4 & $-80(49)$ & 3.0335 \\
\hline $48-2 \mathrm{Al}-0 \mathrm{Si}-4 \mathrm{hr}-215^{\mathrm{d}}$ & 4 & $-30(215)$ & 3.0661 \\
\hline
\end{tabular}

"Calcine particle size $=49 \mu \mathrm{m}$ Mass median diameter

${ }^{d}$ Calcine particle size $215 \mu \mathrm{m}$ Mass median diameter 
the $2 \mathrm{wt} \% \mathrm{Al}$ waste form $(48-2 \mathrm{Al}-0 \mathrm{Si}-4 \mathrm{hr})^{\mathrm{c}}$, the density remained essentially constant suggesting that the waste form might have reached stable composition at about 4 hours of HIPing. This observation will further be discussed in the section Glass Phase Composition. The densities of the $2 \mathrm{wt} \% \mathrm{Al}$ waste forms prepared with as calcined particle sizes finer than -30 mesh $(600 \mu \mathrm{m}$ or $215 \mu \mathrm{m}$ MMD), and particle sizes finer than -80 mesh $(180 \mu \mathrm{m}$ or $49 \mu \mathrm{m}$ MMD) remained similar at 3.0335 , and $3.0661 \mathrm{~g} / \mathrm{cc}$, respectively.

\subsection{4-day MCC-1 Leach Rates}

The total mass loss rates (TMLR) and normalized elemental leach rates versus $\mathrm{Al} w \mathrm{w} \%$ or Si wt\% are presented in Table 4 and Figures $1-4$ for $0-5 \mathrm{wt} \% \mathrm{Al}$ and $3-5$ $w t \%$ Si waste forms. The total mass loss rates (TMLR) and normalized elemental leach rates for $\mathrm{Al}, \mathrm{B}, \mathrm{Ca}, \mathrm{Cd}, \mathrm{Cr}, \mathrm{Cs}, \mathrm{K}, \mathrm{Na}, \mathrm{Si}, \mathrm{Sr}$ and $\mathrm{Zr}$ are all less than $1 \mathrm{~g} / \mathrm{m}^{2}$-day for $2 \mathrm{wt} \% \mathrm{Al}(48-2 \mathrm{Al}-0 \mathrm{Si}-4 \mathrm{hr})$ and $3 \mathrm{wt} \% \mathrm{Si}$ waste forms, and increased as the $\mathrm{Al}$ or the $\mathrm{Si}$ wt\% increased. The leach rates for $\mathrm{Cr}$ and $\mathrm{Cd}$ are low and were less than $\mathrm{I}$ $\mathrm{g} / \mathrm{m}^{2}$-day.

${ }^{\text {eSeries }} 48,70 \mathrm{wt} \%$ calcine loading, 2 wt $\%$ Al, 0 wt $\%$ Si, 4 hours. 


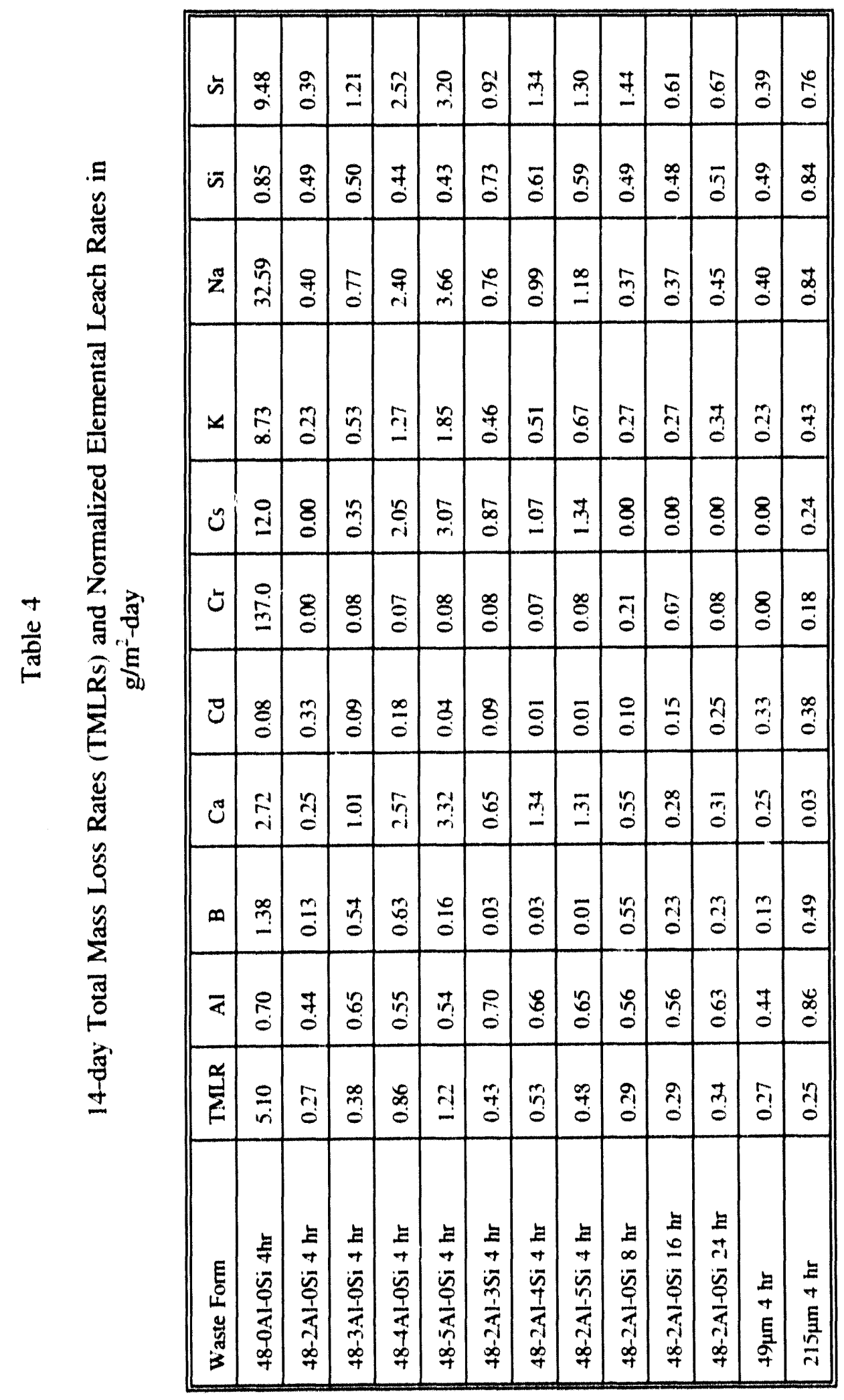




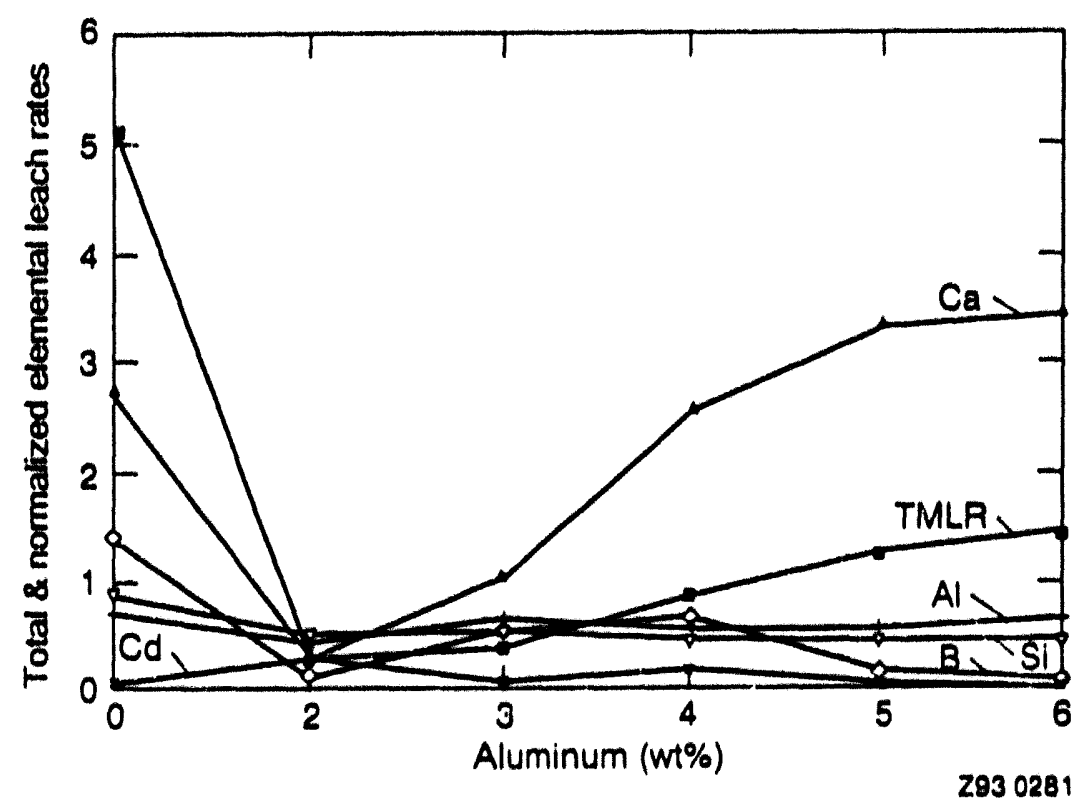

Figure 1. Total and normalized elemental leach rates for $\mathrm{Al}, \mathrm{B}, \mathrm{Ca}, \mathrm{Cd}$ and $\mathrm{Si}$ versus $\mathrm{Al}$ $w t \%$ for waste forms with $0.6 w t \% \mathrm{Al}$ and 0 wt\% Si

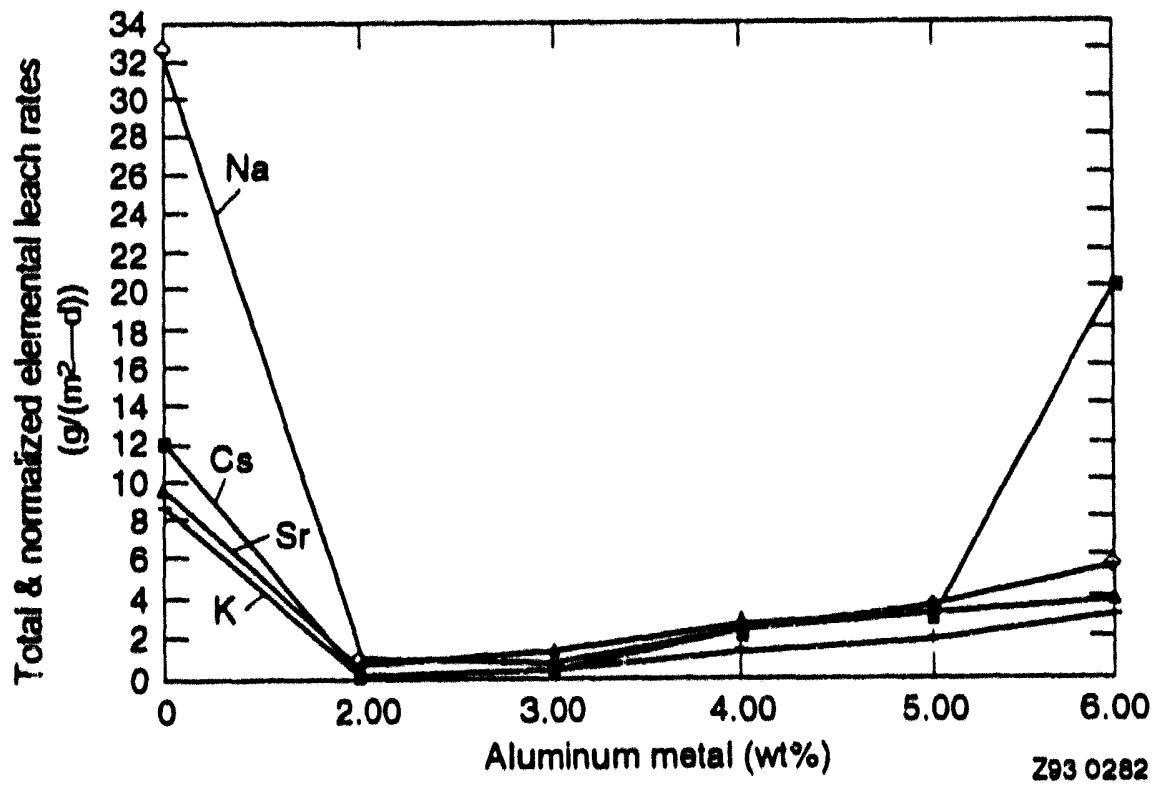

Figure 2. Total and normalized elemental leach rates for $\mathrm{Cs}, \mathrm{K}, \mathrm{Na}$, and $\mathrm{Sr}$ versus $\mathrm{Al}$ $w t \%$ for waste forms with $0.6 \mathrm{wt} \% \mathrm{Al}$ and $0 \mathrm{wt} \% \mathrm{Si}$ 


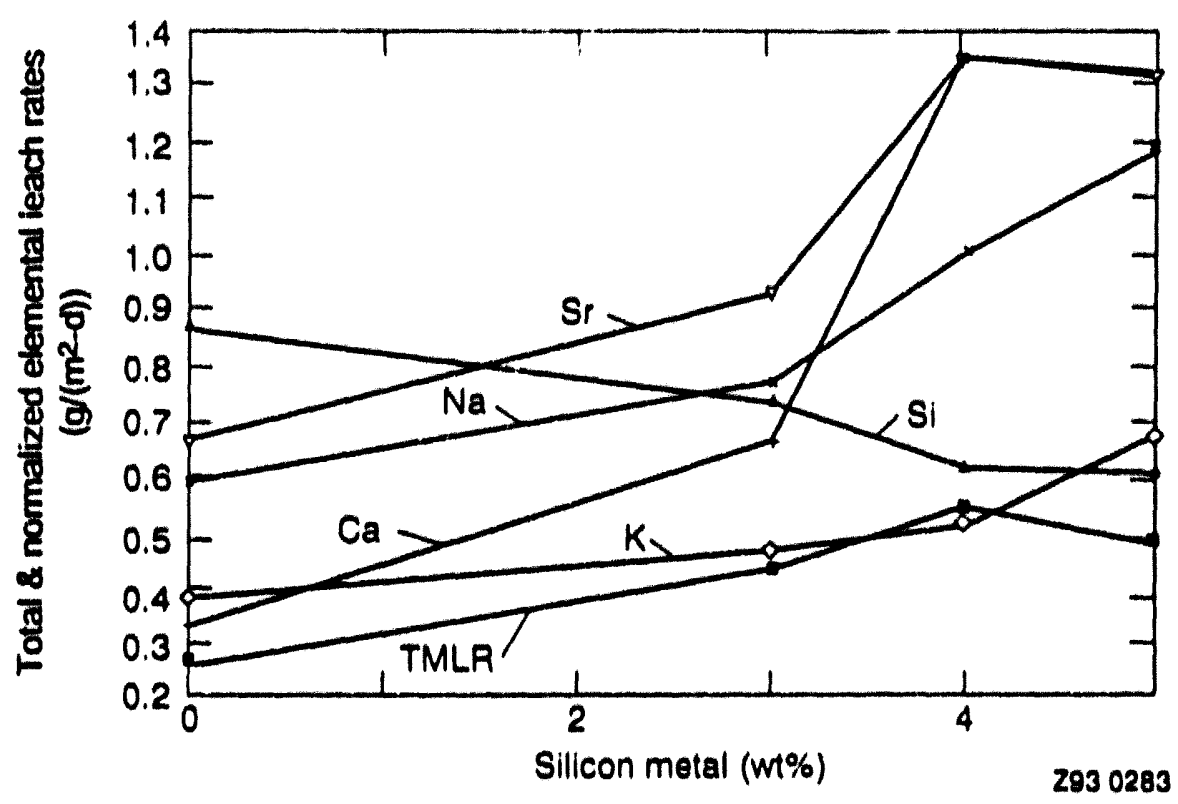

Figure 3. Total and normalized elemental leach rates versus Si wt\% for waste forms with $0-5 w t \% \mathrm{Si}$ and $2 \mathrm{wt \%} \mathrm{Al}$

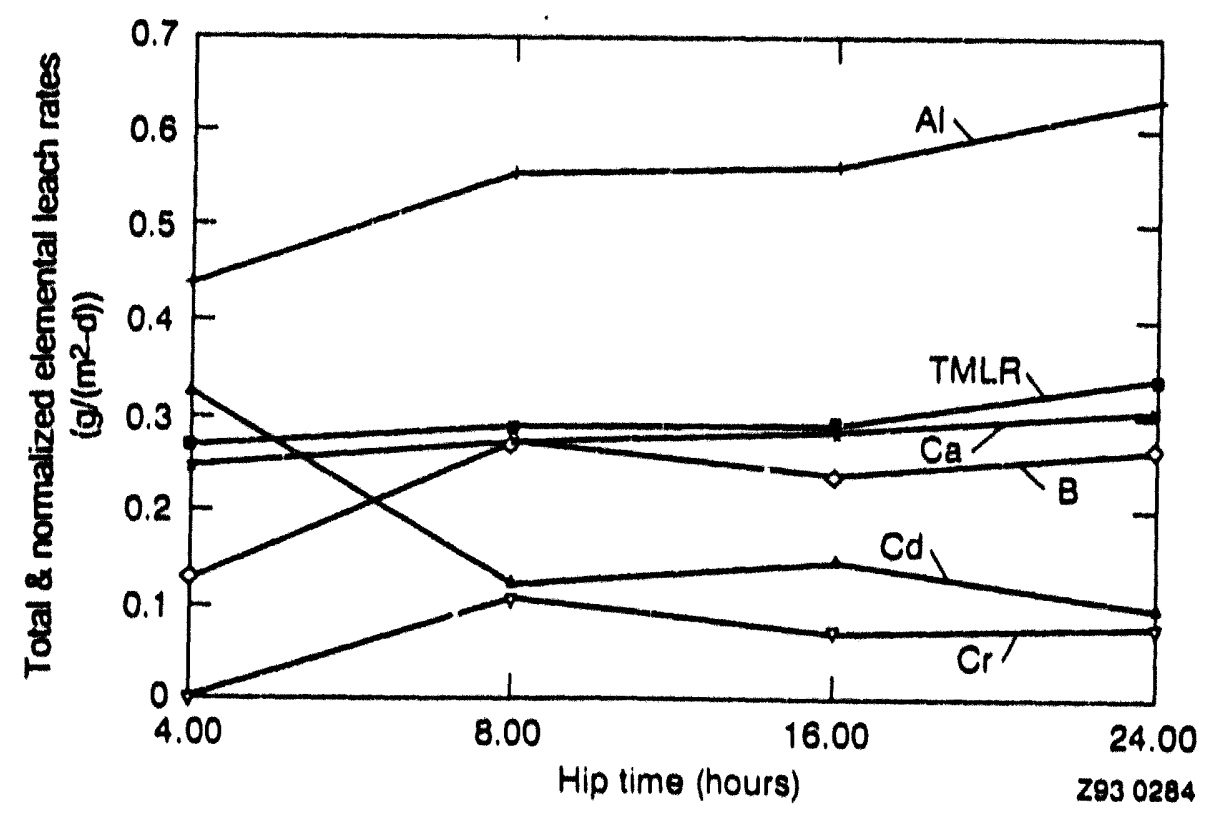

Figure 4. Total and normalized elemental leach rates versus HIP soak time for 4-24 hr waste forms with $2 \mathrm{wt} \% \mathrm{Al}$ and $0 \mathrm{wt} \% \mathrm{Si}$ 


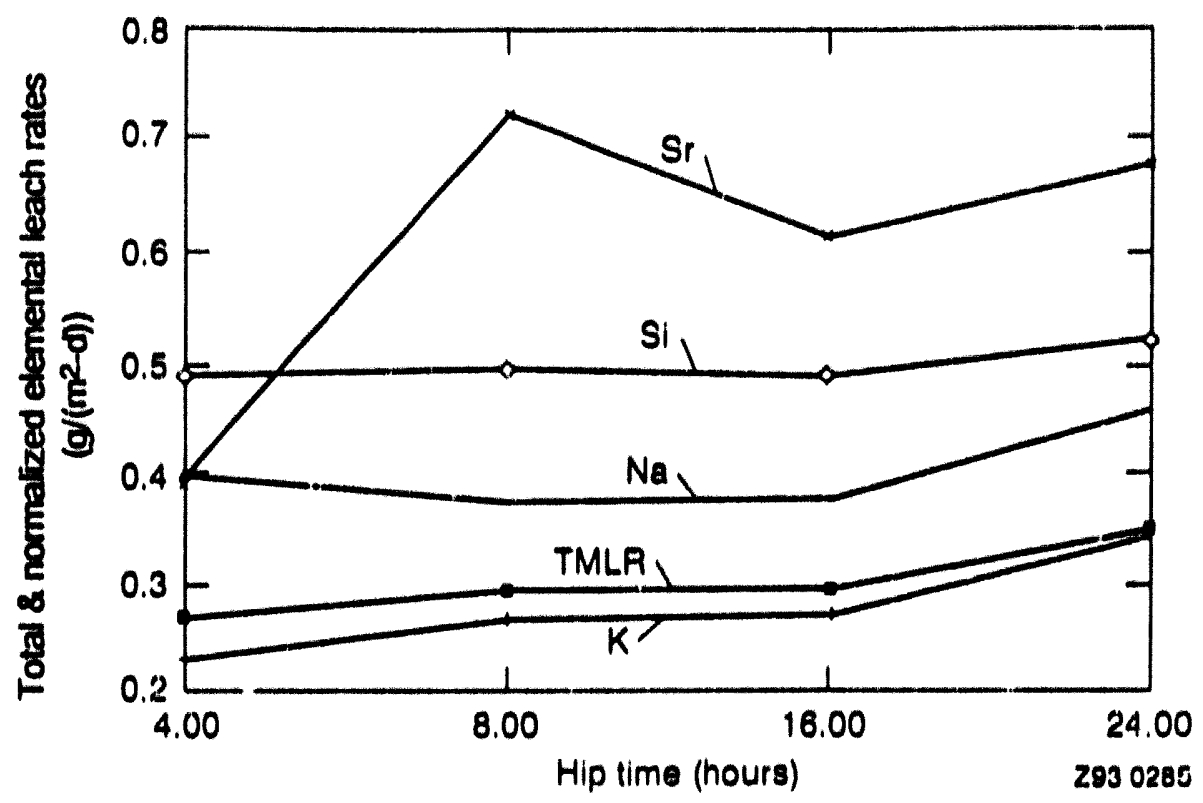

Figure 4. (Continued)

In general, the leach rates increased as the Si content increased in 0-5 wt\% Si waste forms (see Fig. 3). In the tests where the HIP time was varied from 4-24 hours for the 2 wi\% Al waste forms, the leach rates remained essentially constant (see Fig. 4). Most of the leach rates increased with increase in calcine particle size, but remained less than $1 \mathrm{~g} / \mathrm{m}^{2}$-day.

The 28-day MCC-1 static leach tests were also performed for a selected $2 w t \%$ Al galss-ceramic waste forms and are presented in Table 5. The 28-day MCC-1 leach rates for 4 and 24 hour, and ground (180 $\mu \mathrm{m}$ or $49 \mu \mathrm{m}$ MMD) and unground samples (600 $\mu \mathrm{m}$ or 215 $\mu \mathrm{m}$ MMD) are all less than $1 \mathrm{~g} / \mathrm{m}^{2}$-day. As the calcine particle size and the HIPing time increased, the 28-day leach rates of boron and the alkalides increased but reamined less than $1 \mathrm{~g} / \mathrm{m}^{2}$-day.

\subsection{Glass Phase Composition}

The estimated glass phase composition of the waste forms from SEM/EDS and microprobe data are presented in Table 6. In general, as the $\mathrm{Al}$ wt\% increased the $\mathrm{Al}_{2} \mathrm{O}_{3}$ wt\% increased and the $\mathrm{CaO}$ and $\mathrm{SiO}_{2}$ wt\% decreased. It appears that $\mathrm{Al}_{2} \mathrm{O}_{3}$ acts as a glass forming oxide similar to $\mathrm{SiO}_{2}$. The $\mathrm{Al}^{3+}$ ion can be a 4-fold or 6-fold coordination with 
oxygen giving rise to tetrahedral $\mathrm{AlO}_{4}$ or octahedral $\mathrm{AlO}_{n}$ groups. The tetrahedral groups can replace the $\mathrm{SiO}_{4}$ tetrahedra in silicate lattices. Each aluminum ion has a charge of $3+$ as compared with a charge of $4+$ for each silicon ion, an additional unit positive charge must be present to ensure electroneutrality. One alkali metal ion per $\mathrm{Al}^{4+}$ tetrahedron would satisfy this requirement and the alkali metal ions could be accommodated in the interstices between tetrahedral groups. This type of structural arrangement is found in many aluminosilicates such as feldspars and zeolites where the lattices are built up of linked $\mathrm{SiO}_{4}$ and $\mathrm{AlO}_{4}$ groups". The electroneutrality requirement imposes the condition that each grammolecule of aluminum nxide present in the glass requires the presence of one gram-molecule of alkali oxide $\left(\mathrm{Na}_{2} \mathrm{O}, \mathrm{K}_{2} \mathrm{O}\right)$ or alkaline earth oxide $(\mathrm{CaO})$. This requirement is satisfied in Table 6 for glass phase composition. As the $\mathrm{Al}^{3+}$ ion occupy the tetrahedral position, potassium $\mathrm{K}^{1+}$, sodium $\mathrm{Na}^{1+}$ and calcium $\mathrm{Ca}^{2+}$ ions can enter the framework between the tetrahedra, as the feldspars $\mathrm{KAISi}_{1} \mathrm{O}_{n}, \mathrm{NaAlSi}_{1} \mathrm{O}_{n}$ (Albite), and $\mathrm{CaAl}_{2} \mathrm{Si}_{2} \mathrm{O}_{n}$ (Anorthite). Alumina enters alkali silicate glass as network-forming tetrahedra, and albite and anorthite glass consist of mixed $\mathrm{SiO}_{4}$ and $\mathrm{AlO}_{4}$ tetrahedra. Albite and anorthite ciystalline phases were identified in the XRD analysis.

\section{Table 5}

28-day Total Mass Loss Rates and Normalized Elemental Leach Rates in $\mathrm{g} / \mathrm{m}^{2}$-day.

\begin{tabular}{|c|c|c|c|c|c|c|c|c|c|c|c|}
\hline Wunte Form & TMLR & Al & B & Cu & $\mathrm{Cd}$ & $\mathrm{Cr}$ & $C_{n}$ & K & $N_{H}$ & Si & $\mathrm{Sr}$ \\
\hline $\begin{array}{l}2 m \% \text { Al49 } \mu \mathrm{m} \\
4 \mathrm{hr}\end{array}$ & 0.13 & 0.26 & 0.08 & 0.15 & 0.10 & 0.03 & 0.00 & 0.16 & 0.20 & 0.36 & 0.33 \\
\hline $\begin{array}{l}2 m \% A 149 \mu \mathrm{m} \\
24 \mathrm{hr}\end{array}$ & 0.14 & 0.31 & 0.09 & 0.15 & 0.04 & 0.00 & 0.00 & 0.20 & 0.24 & 0.41 & 0.35 \\
\hline $\begin{array}{l}2 \mathrm{wt} \% \text { Al215 } \mu \mathrm{m} \\
4 \mathrm{hr}\end{array}$ & 0.15 & 0.39 & 0.14 & 0.13 & 0.02 & 0.00 & 0.00 & 0.18 & 0.37 & 0.38 & 0.38 \\
\hline $\begin{array}{l}2 w 1 \% \text { Al2 } 15 \mu \mathrm{m} \\
24 \mathrm{hi}\end{array}$ & 0.47 & 0.34 & 0.28 & 0.21 & 0.01 & 0.02 & 0.60 & 0.38 & 0.98 & 0.40 & 0.61 \\
\hline
\end{tabular}




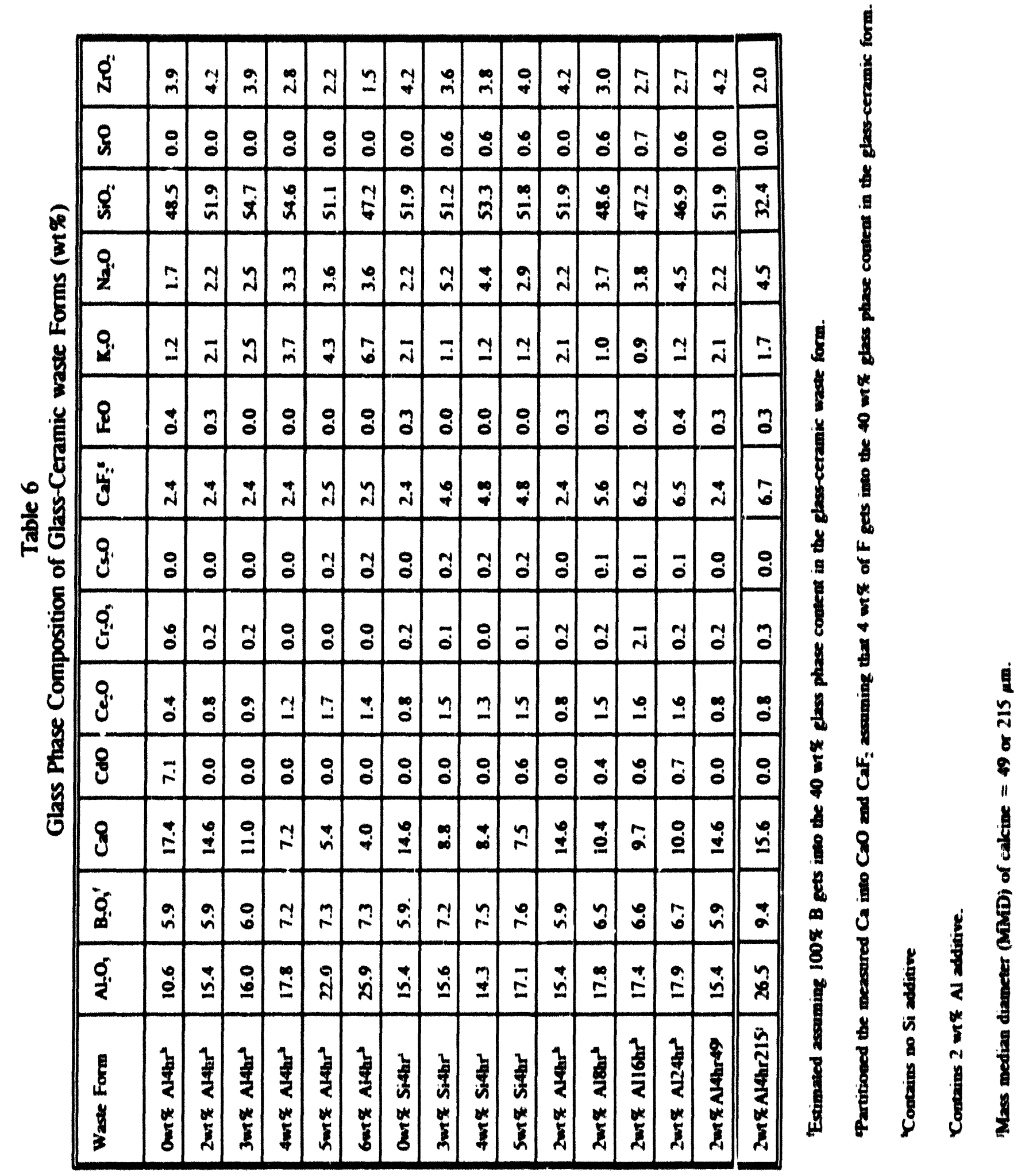


In silicate glass the bonding of oxygen ions to Si ions as a three-dimentional network Si-O-Si is related to the glass composition and durability. The durability is related to the breaking of the network bonds into ionic Si-O groups containing non-bridging oxygens (NBOs).

Therefore, the proportion of NBOs in the glass network is related to durability.

There are three types of oxides in terms of their functions in the glass structure.

These are glass forming oxides $\mathrm{SiO}_{2}, \mathrm{~B}_{2} \mathrm{O}_{1}$ and $\mathrm{P}_{2} \mathrm{O}_{4}$ intermediate oxides $\mathrm{Al}_{2} \mathrm{O}_{1}$, and networkmodifying oxides $\mathrm{CaO}, \mathrm{Na}_{2} \mathrm{O}$, and $\mathrm{K}_{2} \mathrm{O}$. The role of $\mathrm{Al}_{2} \mathrm{O}_{1}$ as glass forming oxide is explained above. The minimum leach rates for the 2 wt\% Al glass-ceramic (48-2Al-0Si-4hr) can be explained in terms of nonbridging oxygens (NBOs) per network forming cation ( $A$ I. $\mathrm{Si})$ in $\mathrm{CaO}-\mathrm{SiO}_{2}-\mathrm{Al}_{2} \mathrm{O}_{1}$ system. The number of $\mathrm{NBOs}=2 \mathrm{R}-4$, where $\mathrm{R}=\left(|\mathrm{CaO}|+2\left|\mathrm{SiO}_{2}\right|\right.$ $\left.+3 \mid \mathrm{Al}_{2} \mathrm{O}_{1}\right\}+\left[\mathrm{K}_{2} \mathrm{O}|+| \mathrm{Na}_{2} \mathrm{O} \mid\right) /\left(\left|\mathrm{SiO}_{2}\right|+2\left|\mathrm{Al}_{2} \mathrm{O}_{1}\right|\right)$ and $|\mathrm{CaO}|$ etc., in the parenthesis are in mole \% of the components in the glass phase. 12 For anorthite glass $\left(\mathrm{C}_{\mathrm{aO}} \mathrm{O}, \mathrm{Al}_{2}, \mathrm{O}_{1}, 2 \mathrm{SiO} \mathrm{O}_{2}\right)$ the ratio $\mathrm{R}=\left(|\mathrm{CaO}|+3\left|\mathrm{~A}_{2} \mathrm{O}_{1}\right|+2\left|\mathrm{SiO}_{2}\right|\right) /\left(2\left|\mathrm{Al}_{2} \mathrm{O}_{1}\right|+\left|\mathrm{SiO}_{2}\right|\right)=2$, where Si an $|\mathrm{A}|$ are network forming cations, and NBOs $=2 R \cdot 4=0$.

The culculated NBOs are $0.49,0.10,0.22,0.35,0.53$ and 0.67 for $0,2,3,4,5$, and 6 wi\% Al waste forms, respectively. In this calcia-alumina-silica system, the average oxygen ions per tetrahedral network forming cation is 2 for $\mathrm{AlO}_{4}$ and $\mathrm{SiO}_{4}$ letrahedral groups in the ulumino-silicate lattice. The NBOs are plotted with reference to Al wI\% in Figure 5 . A minimum occurred for the 2 wt\% Al waste form followed by 3 wt\% Al. This is consistent with the effect of Al on normalized elemental leach rates shown in Figures 1 and 2.

Although the glass-ceramic consists of components greater than 10, the glass phase components can be approximated in terms of a ternary phase diagram. The glass compositions of the waste forms ()-6 wi\% Al are marked on $\mathrm{Al}_{2} \mathrm{O}_{1}-\mathrm{CaO}-\mathrm{SiO} \mathrm{O}_{2}$ ternary phase diagram ${ }^{11,14}$ (see Fig. 6). The glass phase compositions lie in the computibility triangle for silica $\mathrm{SiO}_{2}$ (S), anorthite $\mathrm{CaO} . \mathrm{Al}_{2} \mathrm{O}_{1}, 2 \mathrm{SiO} 2$ (CAS2) and alpha-wollastonite $\mathrm{CaO} . \mathrm{SiO}_{2}$ (CS), for the 0-3 wi\% Al waste forms, and in the compatibility triangle for silica, unorthite and mullite 
$3 \mathrm{Al}_{2} \mathrm{O}_{3}, 2 \mathrm{SiO}_{2}$ (A3S2) for the waste forms $4.6 \mathrm{wt} \% \mathrm{Al}$. In ternary phase diagrams, silica, calcia, and alumina are identified as $S, C$, and $A$, respectively. The glass phase compositions of the $0.6 \mathrm{wt} \% \mathrm{Al}$ waste forms are estimated in terms of the compatibility triangles $\mathrm{S}, \mathrm{CS}$, CAS2 and S, CAS2 and A3S2, and listed in Table 7.

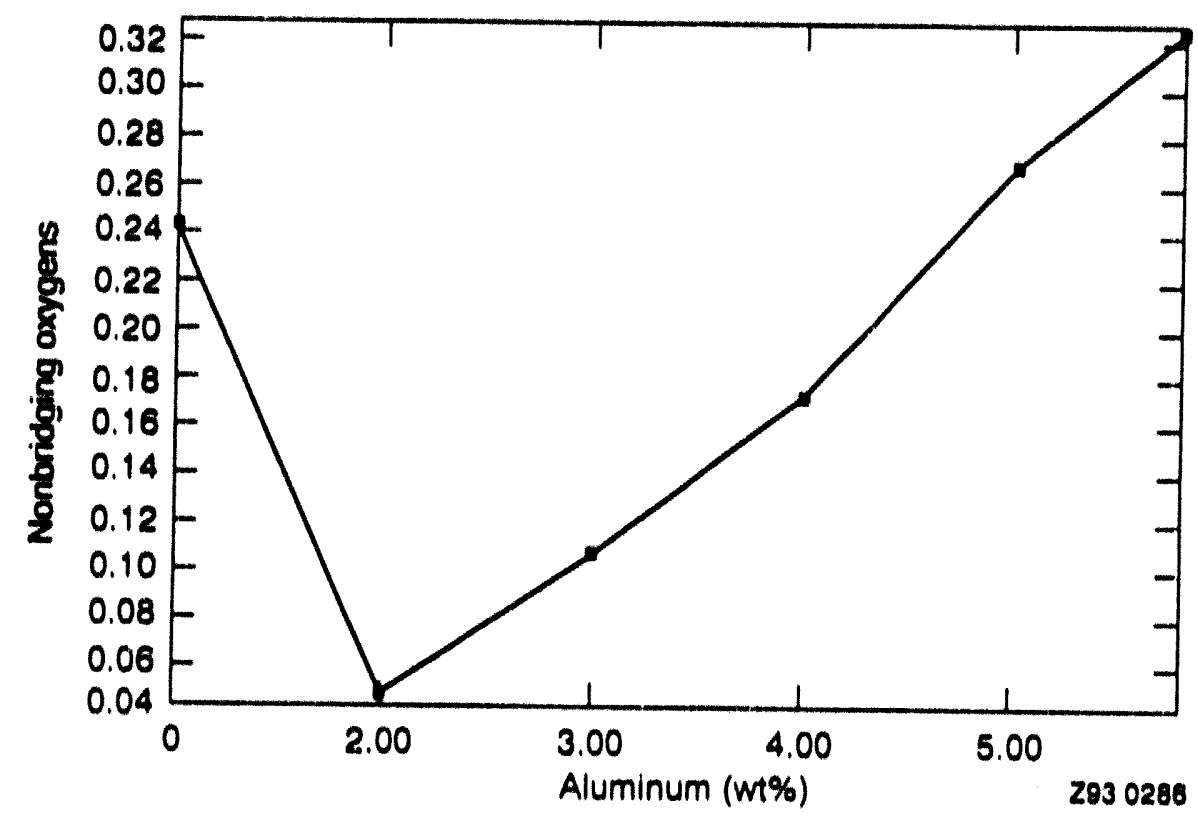

Figure 5. Nonbridging oxygens vesrus $\mathrm{Al}$ wt\% 


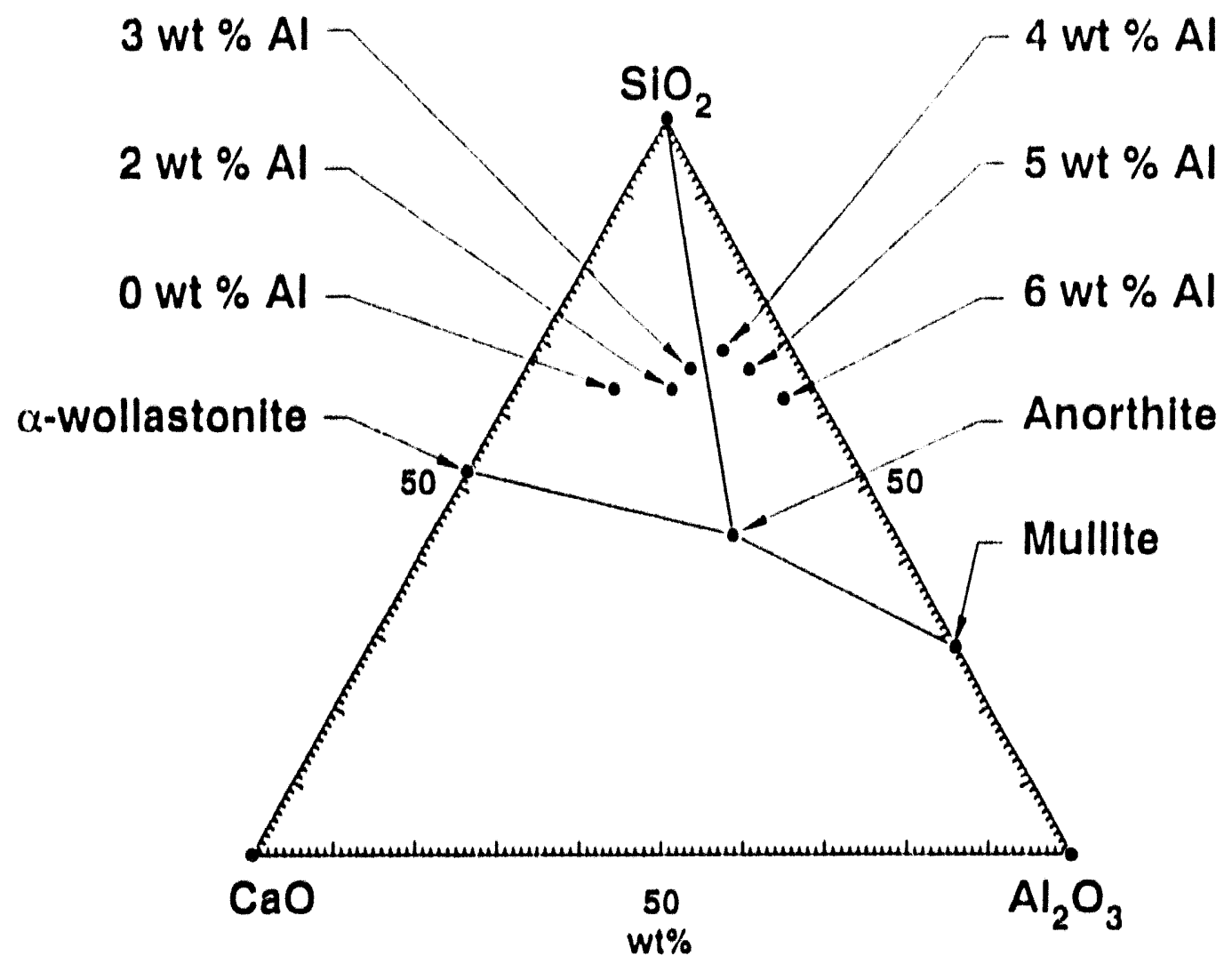

Figure 6. Ternary phase diagram for $\mathrm{CaO}-\mathrm{Al}_{2} \mathrm{O}_{3}-\mathrm{SiO}_{2}$ system showing glass phase compositions for $0-6 w t \%$ Al glass-ceramic waste forms

Table 7

Glass Phase Composition in Compatibility Triangles

\begin{tabular}{||c|l|l|l||}
\hline $\begin{array}{l}\text { Aluminum wt\% } \\
\text { (particle size in MMD) }\end{array}$ & $\begin{array}{l}\text { Anorthite } \\
(\mathrm{CAS} 2)\end{array}$ & Silica (S) & Alpha-Wollastonite (CS) \\
\hline $0.0(49 \mu \mathrm{m})$ & 40.0 & 30.0 & 30.0 \\
\hline $2.0(49 \mu \mathrm{m})$ & 58.0 & 34.0 & 8.0 \\
\hline $3.0(49 \mu \mathrm{m})$ & 58.0 & 42.0 & 0.0 \\
\hline Aluminum wt\% & $\begin{array}{l}\text { Anorthite } \\
(\text { CAS2) }\end{array}$ & Silica (S) & Mullite (A3S2) \\
\hline $4.0(49 \mu \mathrm{m})$ & 41.0 & 47.0 & 12.0 \\
\hline $5.0(49 \mu \mathrm{m})$ & 28.0 & 34.0 & 38.0 \\
\hline $6.0(49 \mu \mathrm{m})$ & 23.0 & 39.0 & 38.0 \\
\hline
\end{tabular}


It appears that the anorthite is a major glass phase (58 wt\%, non-stoichiometric composition of anorthite glass) coinponent for 2 and $3 \mathrm{wt} \% \mathrm{Al}$ waste forms. Anorthite crystals were not identified in the glass phase of these waste forms that were HIPed for 4 hours. The major glass phase composition for the $2 \mathrm{wt} \% \mathrm{Al}$ waste form prepared with $215 \mu \mathrm{m}$ MMD calcine appear to be anorthite at $100 \mathrm{wt} \%$ (stoichiometric composition of anorthite glass). In the foregoing discussion, the nucleation and growth kinetics are discussed. The rate at which a liquid can be transformed into a crystal is given by thefollowing equation.

$$
X_{1}=1-\exp \left(-\Pi / 3 U^{3} I t^{4}\right)
$$

where, $X_{1}$ is the volume fraction crystallized after time $t, U$ is the crystal growth rate, and $I$ is the nucleation rate. Thus the glass formation which requires $X_{1}$ to remain below the detectable limit of about $10^{\text {th }}$ necessiates either $U$ or $I$ or both be low, or $t$ be low. High melt viscosity lowers both U and I. Also shorter periods of HIP soak time, for example 4 hours of HIP time, might have caused no crystal growth or nucleation. This will further be discussed in the section for time effect on 16-24 hour samples.

The effect of Si reactant on waste form characteristics are discussed. In general, the TMLRs and normalized elemental leach rates increased as the Si wt\% increased from 0 wt $\%$ to $5 \mathrm{wt} \%$ in waste forms (waste forms containing $0,3,4$ and $5 \mathrm{wt} \%$ Si metal and $2 \mathrm{wt} \%$ aluminum metal powders) as shown in Figure 3. However, the Si elemental leach rates decreased. As marked in Figure 7, the glass phase compositions for 0-4 wt\% Si waste forms lie within the phase compatibility triangle for $\mathrm{SiO}_{2}(\mathrm{~S})$, anorthite (CAS2), and alphawollastonite (CS). For the $5 \mathrm{wt} \%$ Si waste form, the glass phase composition lies in the phase compatibility triangle for $\mathrm{SiO}_{2}(\mathrm{~S})$, anorthite (CAS2), and mullite (A3S2) ${ }^{13,14}$. These crystalline phases were not observed in 0-4 wt\% Si samples by XRD. It appears that because of high viscosity of the glass phase, the nucleation and growth rates for these crystalline phases are low. The composition of $58 \mathrm{wt} \%$ for the anorthite phase in the glass is higher for $0 \mathrm{wt} \%$ Si waste form compared to the 3,4, and $5 \mathrm{wt} \%$ Si waste forms, and the $0 \mathrm{wt} \% \mathrm{Si}$ waste form is highly durable. The estimated NBOs per network forming cation (Si, Al) are 
$0.10,0.23,0.22$ and 0.38 for the waste forms $0,3,4$, and $5 \mathrm{wt} \% \mathrm{Si}$, respectively. Because of low NBOs per cation, the leach rates for the waste form $0 \mathrm{wt} \%$ Si must be less than the other three waste forms. Scanning electron micrographs indicate micro cracks in all but the waste form $0 \mathrm{wt} \% \mathrm{Si}$, and the leach rates for this waste form are consistently lower than the leach rates for the three $\mathrm{Si}$ added waste forms.

The effect of HIP soak time is studied for the $2 \mathrm{wt} \% \mathrm{Al}$ waste form (48-2Al-0Si). Total mass loss rates (TMLRs) and the normalized elemental leach rates remained essentially constant as the HIP soak time was varied from 4 to 24 hours (see Fig. 4). Glass phase compositions obtained from SEM/EDS and microprobe analyses are presented in Table 6. The compositions for 8 to 24 hour waste forms are similar to the 4 hour waste form. The compositions for $4,8,16$ and 24 hour waste forms are marked in the ternary phase digram (see Fig. 8) for the $\mathrm{Al}_{2} \mathrm{O}_{3} \cdot \mathrm{CaO} \cdot \mathrm{SiO}_{2}$ system. ${ }^{13}$ The compositions for 4-24 hour waste forms lie in the silica $\left(\mathrm{SiO}_{2}\right)$, anorthite $\left(\mathrm{CaO} \cdot \mathrm{Al}_{2} \mathrm{O}_{3} \cdot 2 \mathrm{SiO}_{2}\right)$ and alpha-wollastonite $\left(\mathrm{CaO} . \mathrm{SiO}_{2}\right)$ compatibility triangle. The glass phase compositions for S, CS and A3S2 are presented in Table 8. The phase compositions are similar for 4-24 hour samples. X-ray diffraction analysis identified anorthite in 16 and 24 hour waste forms. However, anorthite crystals were not observed in 4 and 8 hour waste forms. It appears that longer 16-24 hour soak times are needed for nucleation and growth of anorthite crystals. 


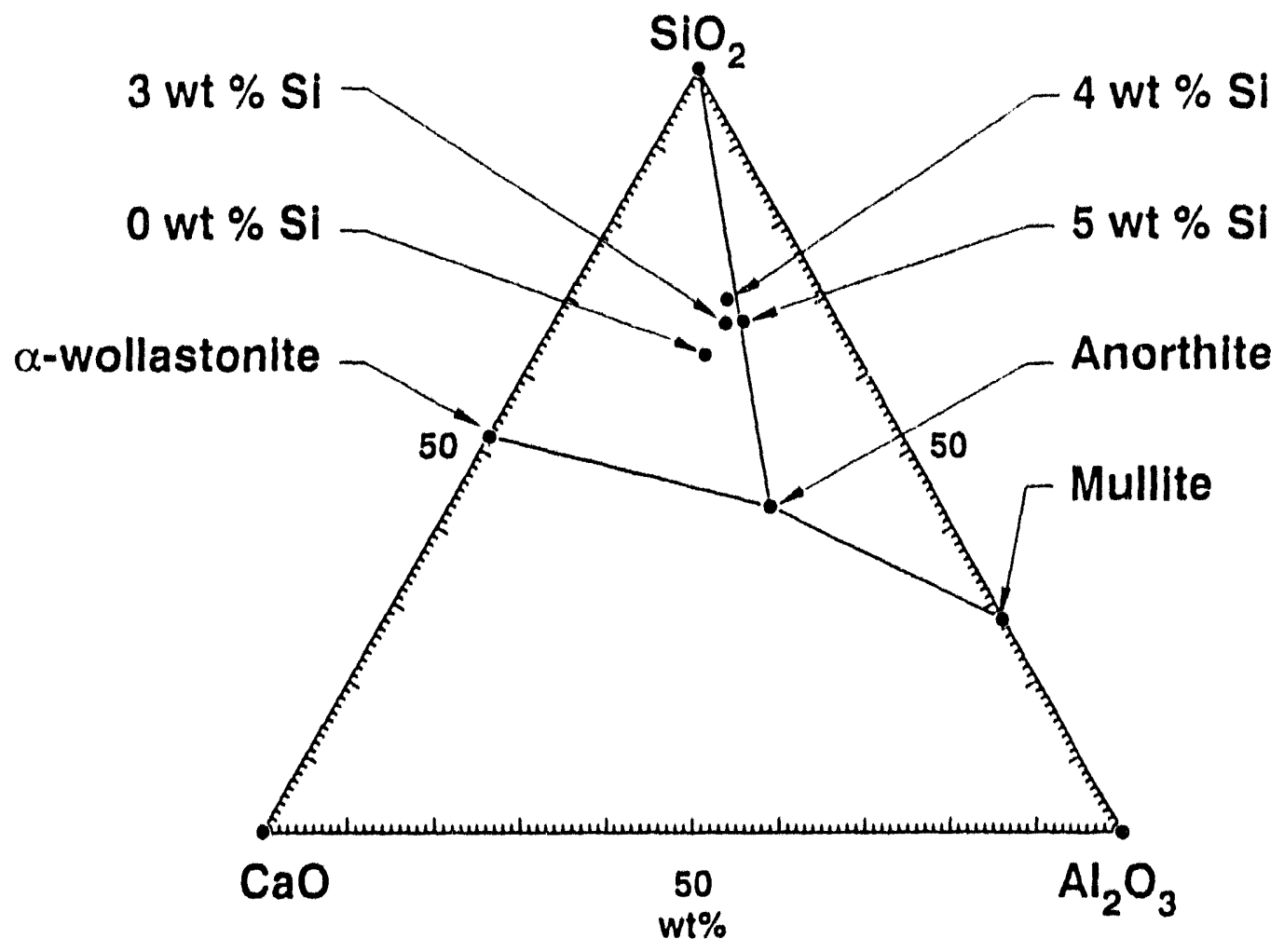

Figure 7. Ternary phase diagram for $\mathrm{CaO}-\mathrm{Al}_{2} \mathrm{O}_{3}-\mathrm{SiO}_{2}$ system showing glass phase compositions for $0-5 \mathrm{wt} \% \mathrm{Si}$ glass-ceramic waste forms

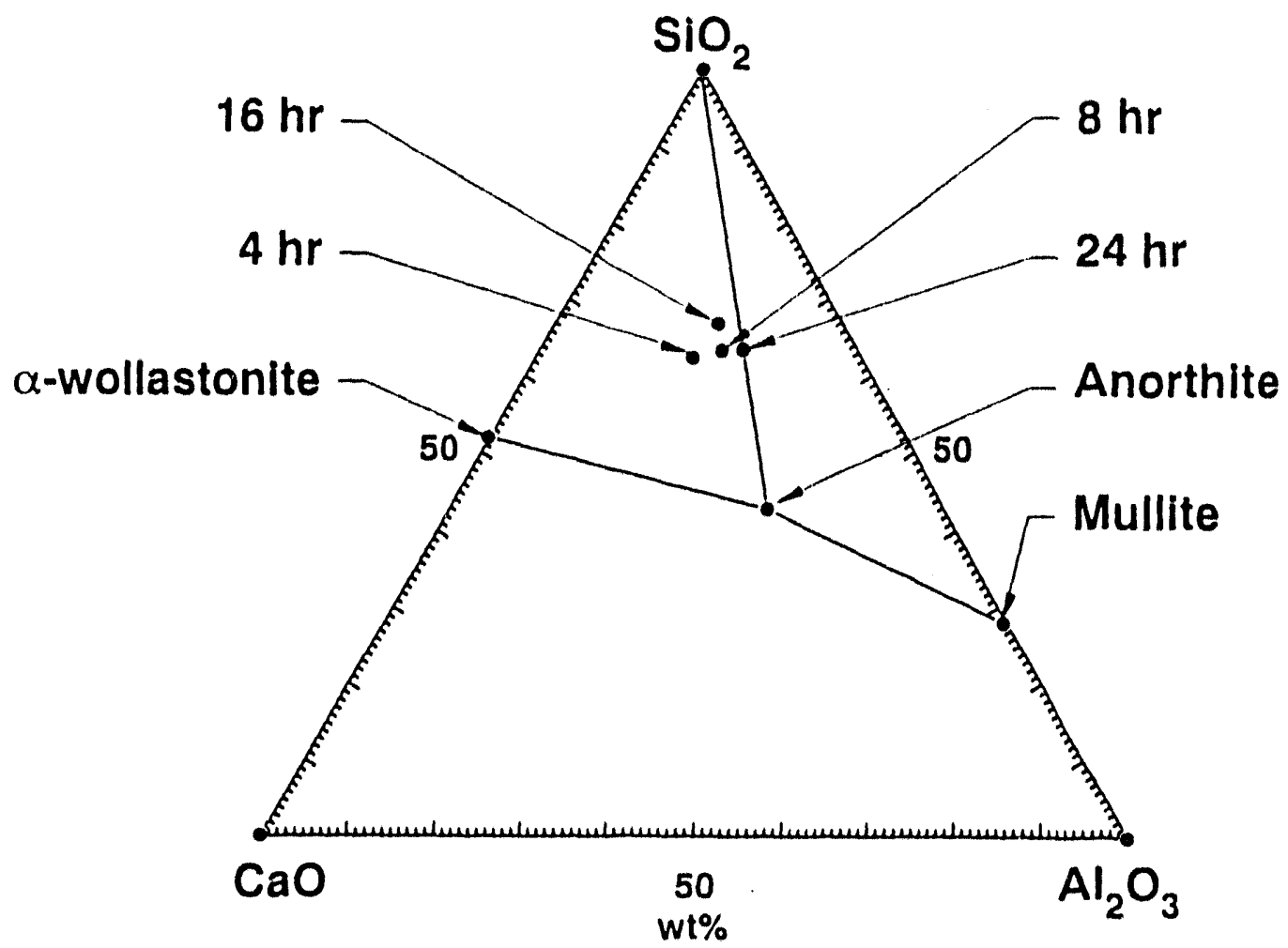

Figure 8. Ternary phase diagram for $\mathrm{CaO}-\mathrm{Al}_{2} \mathrm{O}_{3}-\mathrm{SiO}_{2}$ system showing glass phase compositions for 4-24 hour glass-ceramic waste forms 
Table 8

Glass Phase Composition in Phase Compatibility Triangle

\begin{tabular}{||c|l|l|c|}
\hline $\begin{array}{l}\text { HIP Soak Time } \\
\text { (Hours) }\end{array}$ & $\begin{array}{l}\text { Anorthite } \\
\text { (CAS2) }\end{array}$ & Silica (S) & Alpha-Wollastonite (CS) \\
\hline 4.0 & 58.0 & 34.0 & 8.0 \\
\hline 8.0 & 58.0 & 34.0 & 8.0 \\
\hline 16.0 & 60.0 & 34.0 & 6.0 \\
\hline 24.0 & 64.0 & 33.0 & 3.0 \\
\hline
\end{tabular}

\subsection{Crystalline Phases}

The XRD results of crystalline phases are presented in Table 9 for $2 \mathrm{wt} \%$ Al waste forms that were prepared by HIPing for $4,8,16$ and 24 hours. Zircoria $\left(\mathrm{ZrO}_{2}\right)$, calcium fluoride $\left(\mathrm{CaF}_{2}\right)$ and zircon $\left(\mathrm{ZrSiO}_{4}\right)$ were identified as major crystalline phases in all 4 to 24 hour samples. Albite $\left(\mathrm{NaAlSi}_{3} \mathrm{O}_{8}\right)$ was identified in $4 \mathrm{hr}(49$ and $215 \mu \mathrm{m}), 8 \mathrm{hr}(49 \mu \mathrm{m}), 16 \mathrm{hr}$ $(49 \mu \mathrm{m})$ and $24 \mathrm{hr}\left(49\right.$ and $215 \mu \mathrm{m}$ calcine) samples. Anorthite $\left(\mathrm{CaAl}_{2} \mathrm{Si}_{2} \mathrm{O}_{8}\right)$ was indentified in $4 \mathrm{hr}(49$ and $215 \mu \mathrm{m}), 16 \mathrm{hr}(49 \mu \mathrm{m})$ and $24 \mathrm{hr}(49 \mu \mathrm{m})$ waste form samples. These crystalline phases are durable and the elemental leach rates for $\mathrm{Al}, \mathrm{Na}, \mathrm{Ca}$ and $\mathrm{Si}$ are consistently low. It appears that in the glass framework $\mathrm{Al}^{3+}$ ion must have replaced some of the $\mathrm{Si}^{4+}$ to make a framework with negative charge that is balanced by large $\mathrm{Na}^{1+}$, and $\mathrm{Ca}^{2+}$ in interstitial positions as in albite $\left(\mathrm{NaAlSi}_{3} \mathrm{O}_{8}\right)$, anorthite $\left(\mathrm{CaAl}_{2} \mathrm{Si}_{2} \mathrm{O}_{8}\right)$, and the like. ${ }^{12}$ Metallic $\mathrm{Cd}$ and $\mathrm{CdS}$ phases were identified in XRD, and the $\mathrm{Cd}$ leach rates were low. SEM/EDS did not identify $\mathrm{Cr}$ containing crystals, so the low $\mathrm{Cr}$ leach rates may be attributed to the durable glass phase. However, TEM identified $\mathrm{Cr}$,and $\mathrm{CdS}$ microsrystals in the glass phase. 


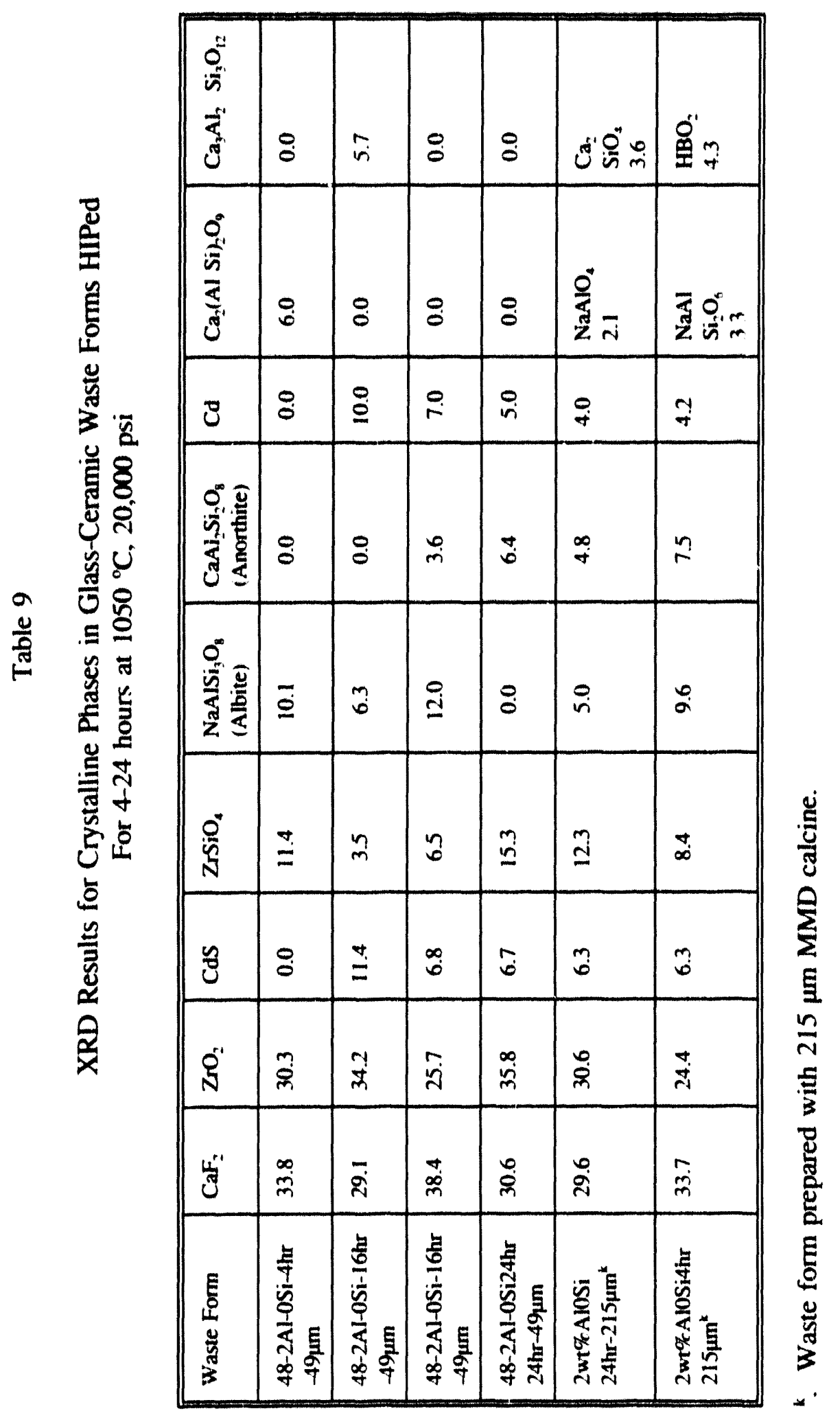




\subsection{Microstructure}

The backscatter scanning electron micrographs for 0-6wt\% Al (48-0Al-0Si-4hr to 48 6Al-0Si-4hr) waste forms shown in Figure $9(a, b, c, d, e, f)$ at $200 \mathrm{X}$ consist of white, gray and dark regions. The white areas in Figure $9(\mathrm{a})$ are $\mathrm{ZrSiO}_{4}$ crystals for the low viscosity glassceramic waste form 0 wt\% Al (48-0Al-0Si-4hr) and in Figure 9(b,c,d,e,f) the white patchy crystalline grains are $\mathrm{ZrO}_{2}, \mathrm{ZrSiO}_{4}$, and $\mathrm{CdS}$, and gray grains in between white spots are $\mathrm{CaF}_{2}$ crystals. These crystals are uniformly distributed for the waste forms prepared with 2, 3, 4, 5 and $6 \mathrm{wt} \% \mathrm{Al}$ metal powder. The dark areas are the glassy regions. The micrograph at 500 $X$ in Figure 10(a) show large zircon and calcium fluoride crystals in the glass region of the 0 wt\% Al waste form. As the Al content increased in the formulation, the glass regions in 2-6 wt\% Al waste forms in Figures 10(b-f) appear to be devoid of crystalline grains. It appears from these micrographs that the viscosity of the $0 \mathrm{wt} \% \mathrm{Al}$ glass is relatively low compared to $2,3,4,5$, and 6 wt $\%$ Al waste forms. Possibly, the impediment in crystal growth has been caused by increase in the viscosity of the glass phase in these waste forms. Transgranular cracks are seen in 4, 5, and 6 wt\% Al waste forms, attributing to the higher leach rates observed. 


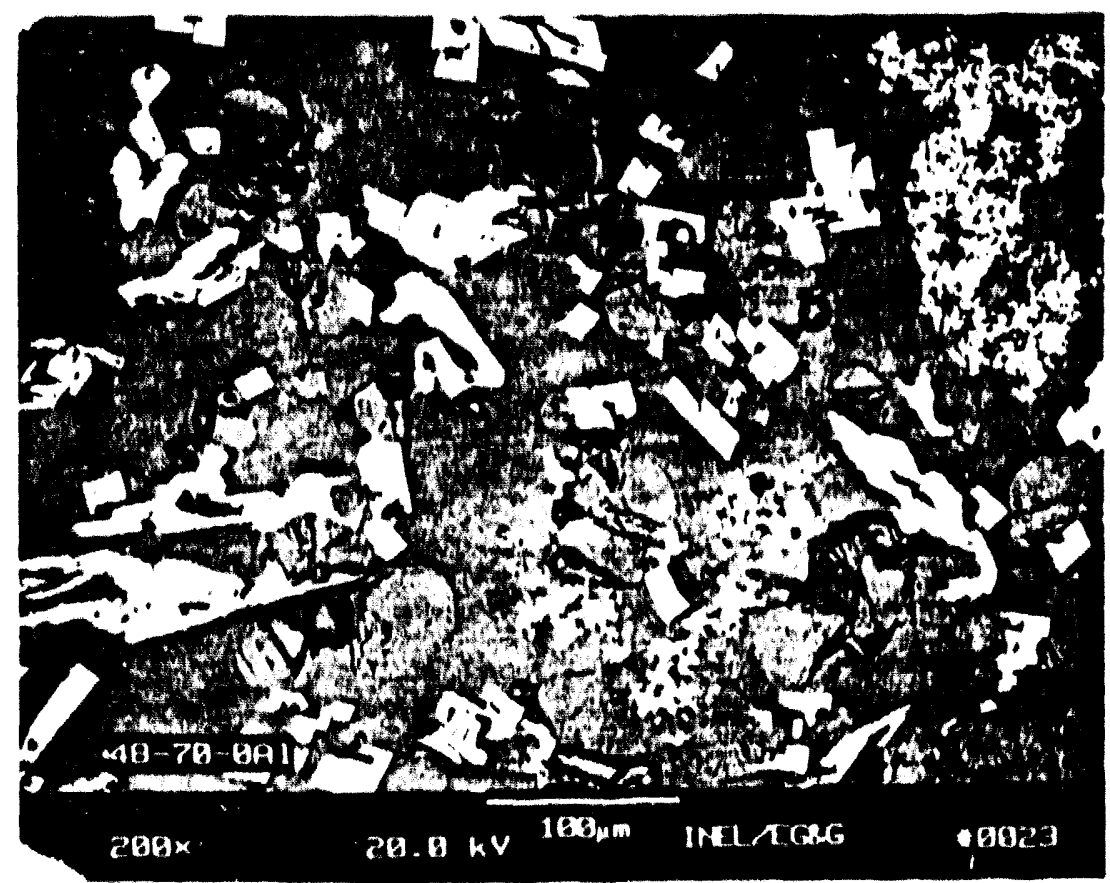

9(a). 48-0Al-OSi-4hr Waste Form, 200X

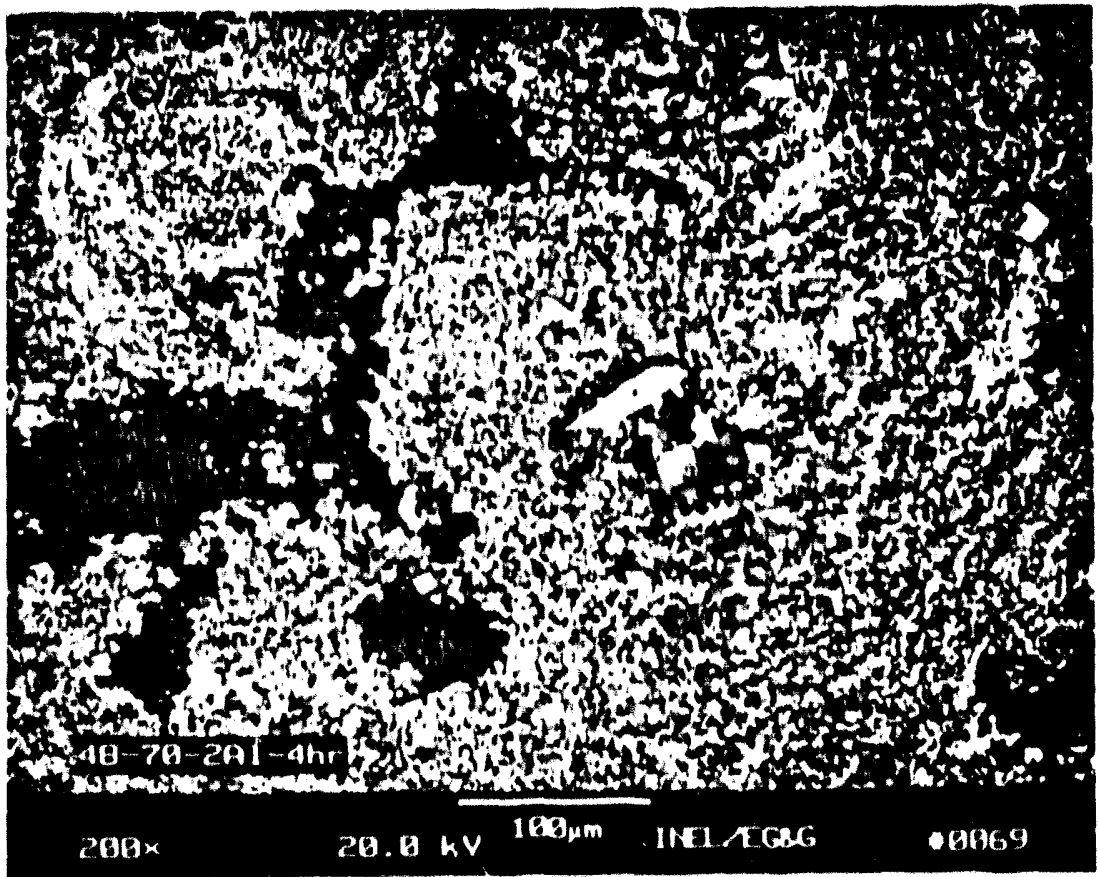

9(b). 48-2Al-0Si-4hr Waste Form, 2(X)X

Figure 9) SEM Micrographs al $200 x$ for 0 - 6 wl\% Al (ilass-(cramic

Waste Forms 


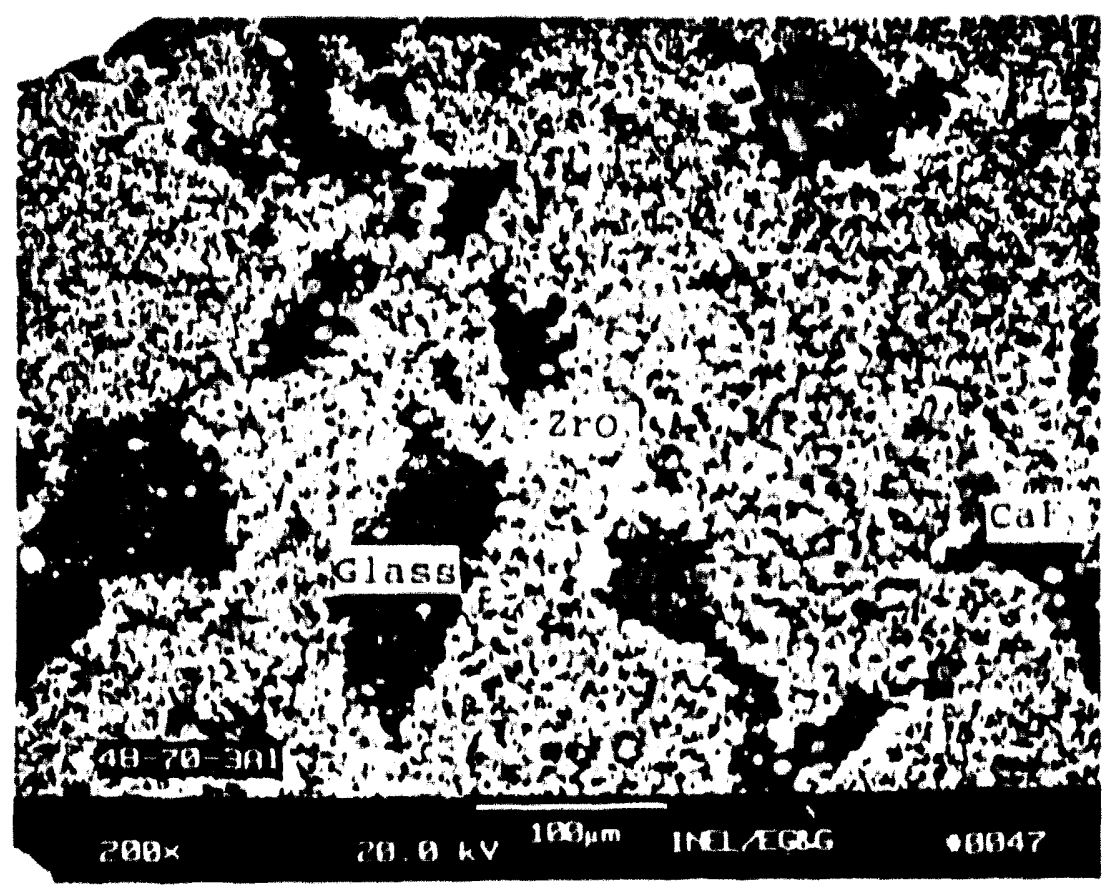

9(c), 48-3Al-0Si-4hr Waste form, 200X

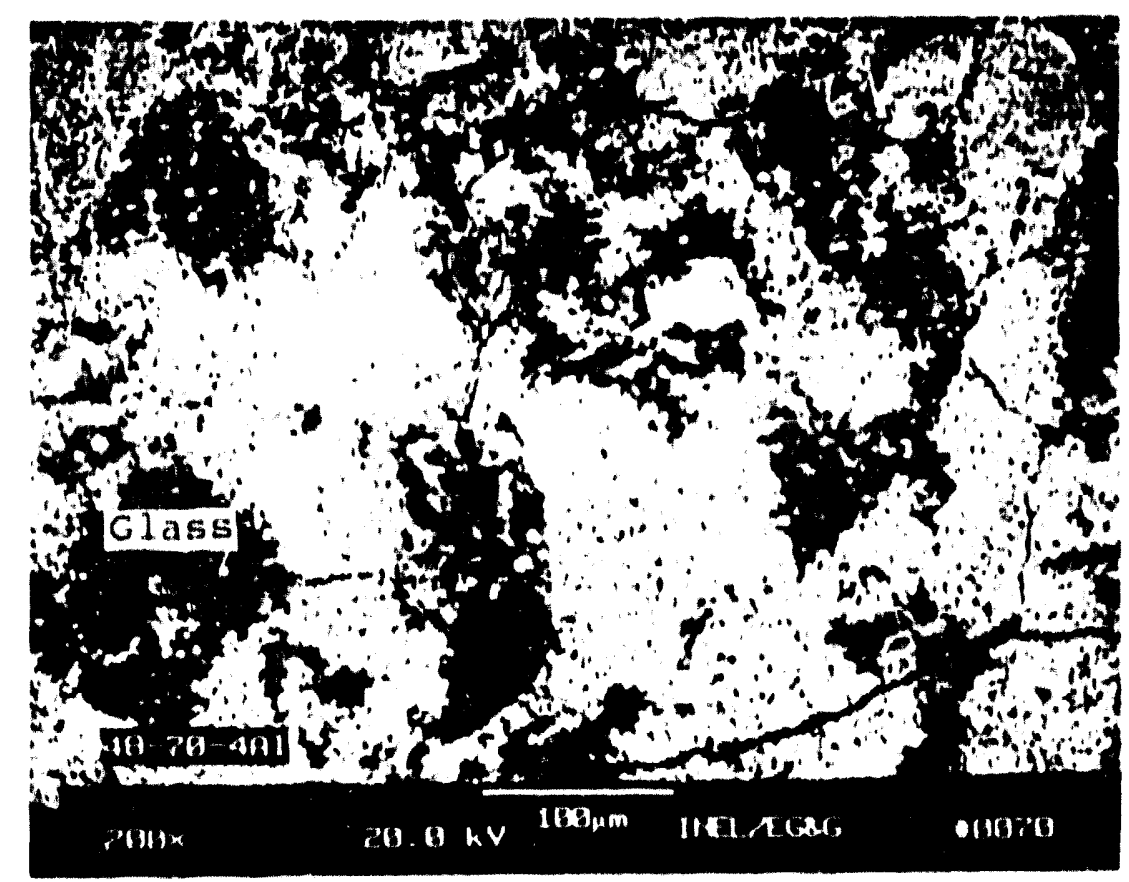

9(d). 48-4Al-0Si-4hr Waste Form, 200X

Figure 9. SEM Micrographs at $200 \times$ for 0.6 wt\% Al Glass Ceramic Waste Forms 


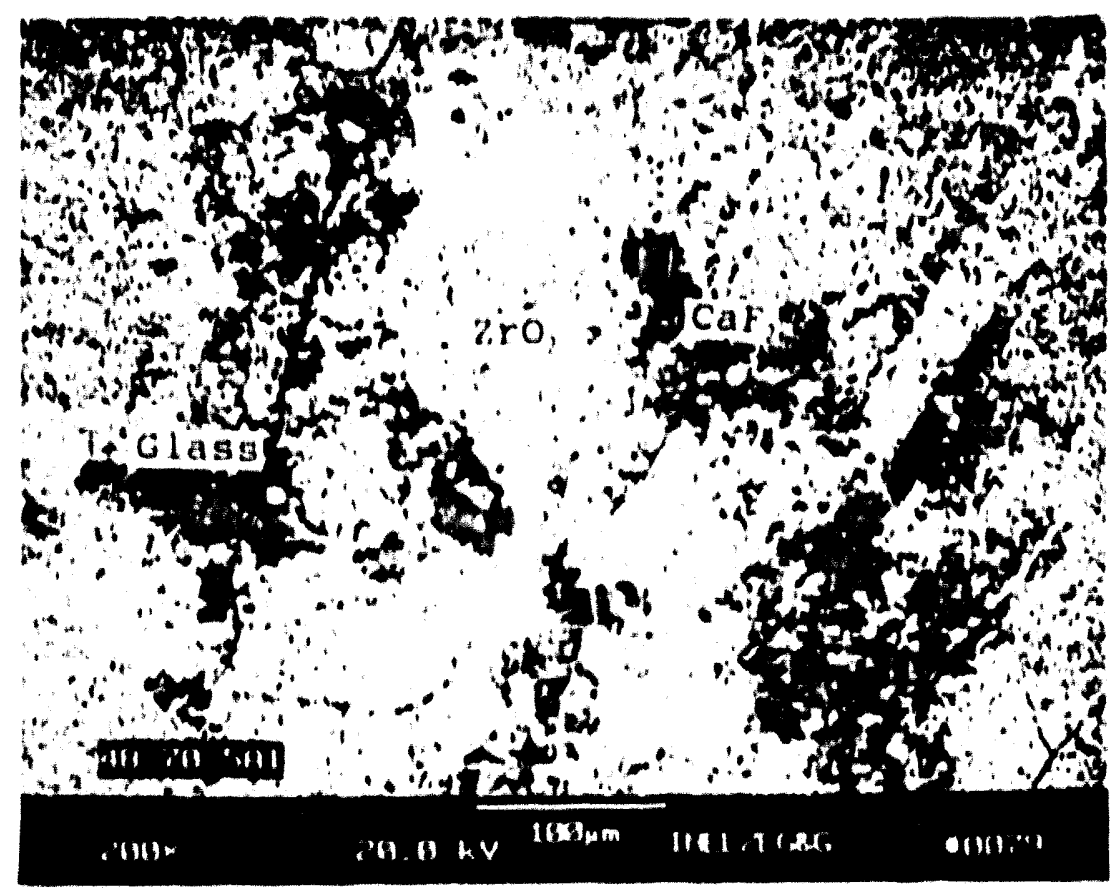

9(c) 48.5Al-0Si-4hr Waste Form, 200X

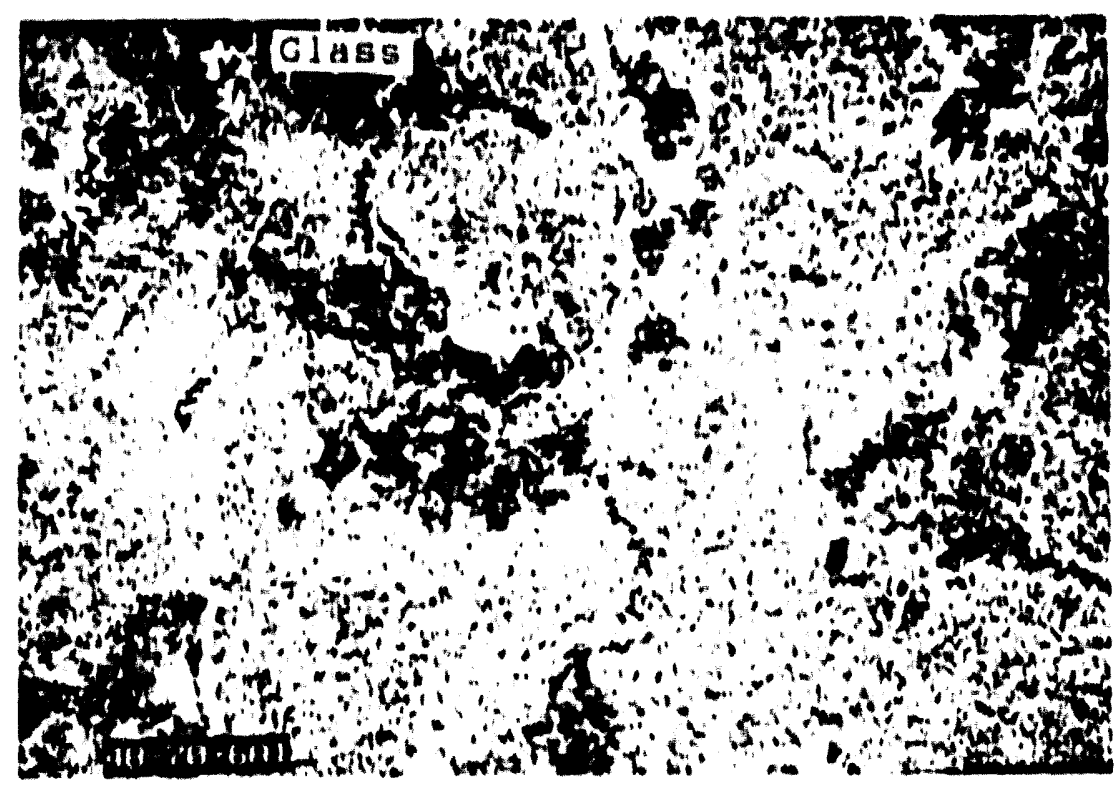

9(f), 48-6Al-0Si-4hr Waste Form, 20X)X

Figure 1). SI:M Micrographs at 200X for () - 6 wi\% Al cilass-Ceramic Waste Forms 


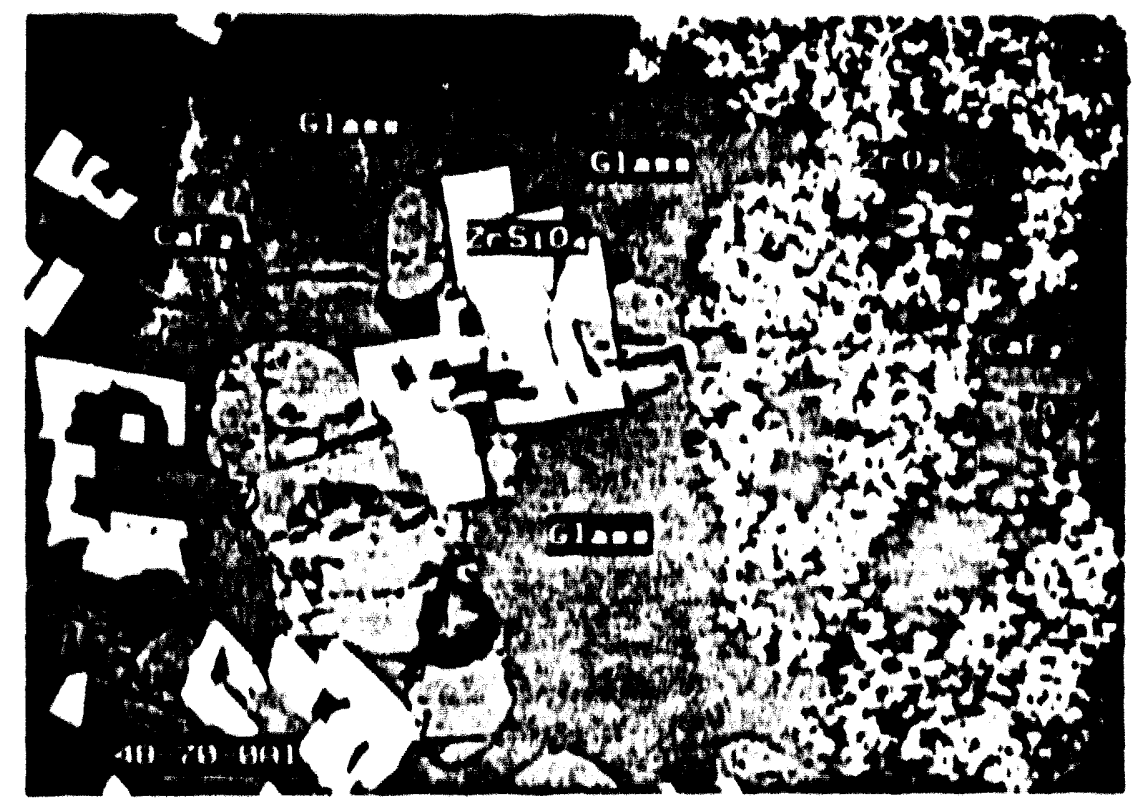

10(a). 48-0Al-0Si-4hr Waste Form, $5(x) \mathrm{X}$

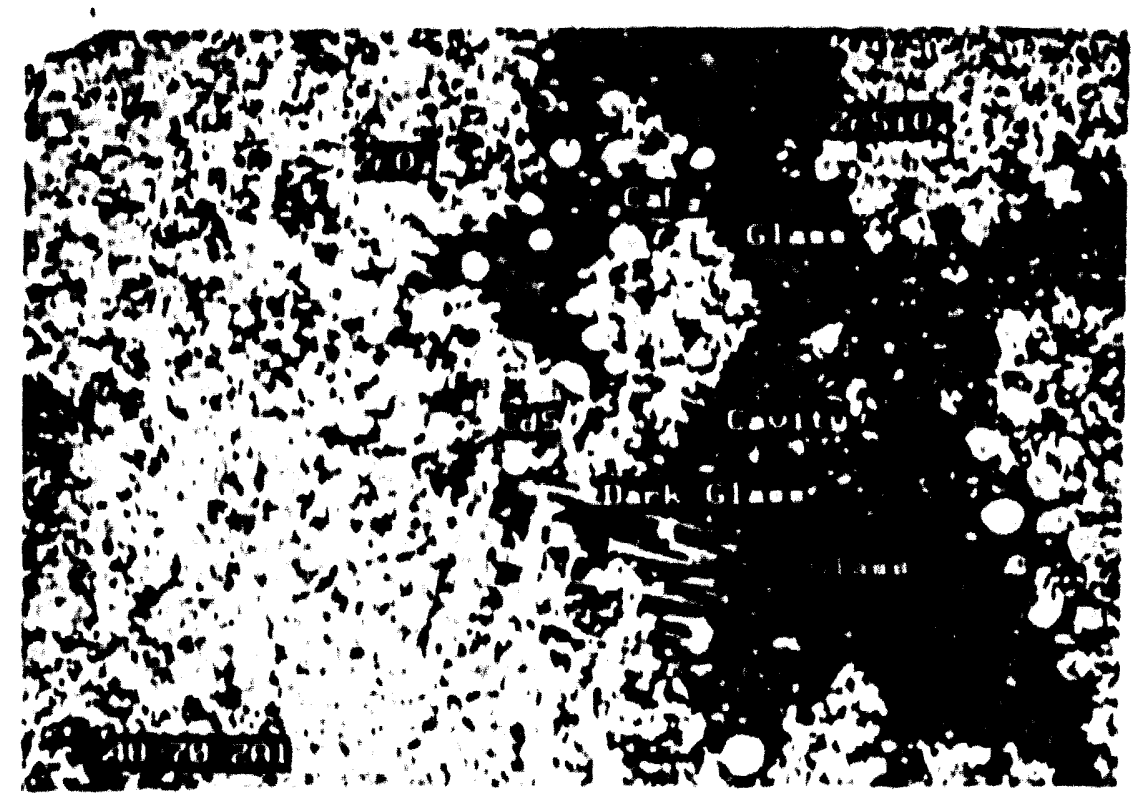

10(b), 48-2Al-0Si-4hr Waste Form, 500XX

Figure 10. St:M Micrographs al $5(0) x$ for $0 \cdot 6$ wit $\mathrm{Al}$ Giass ceramic Wasle forms 


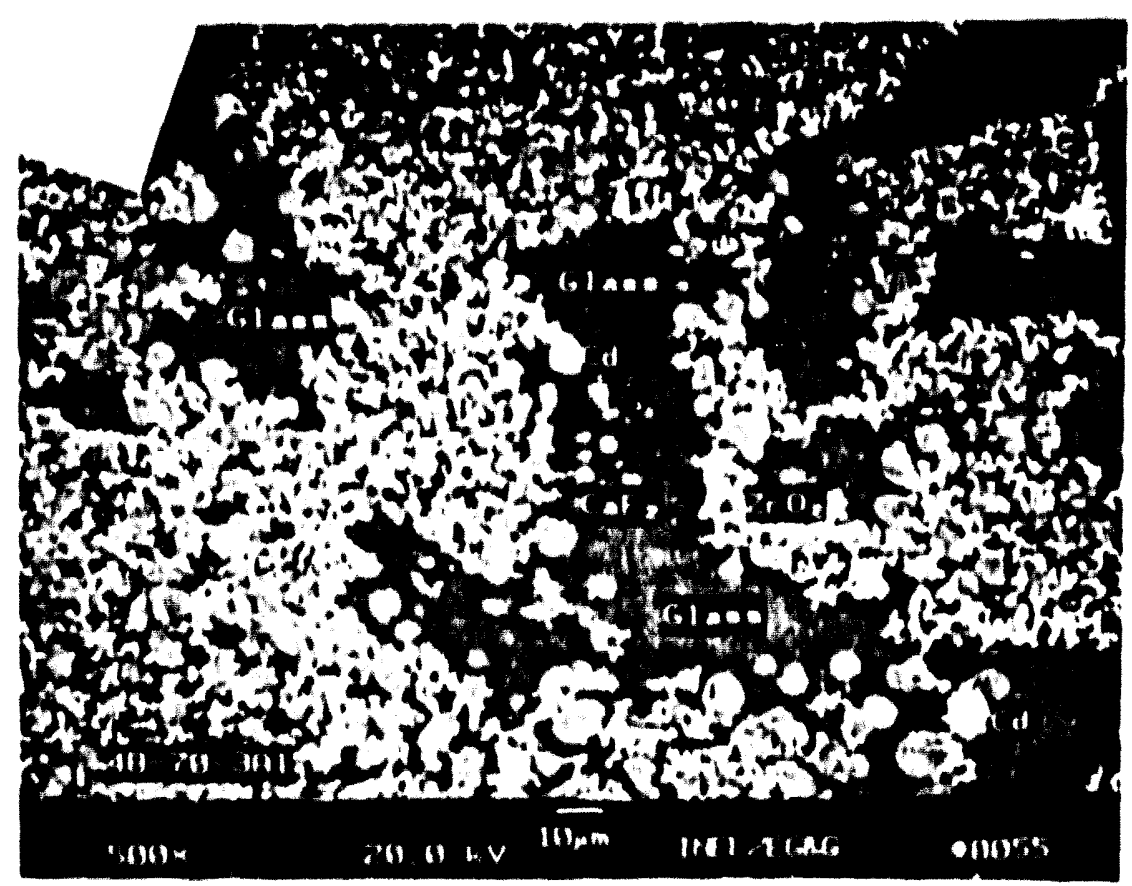

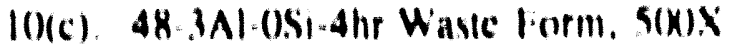

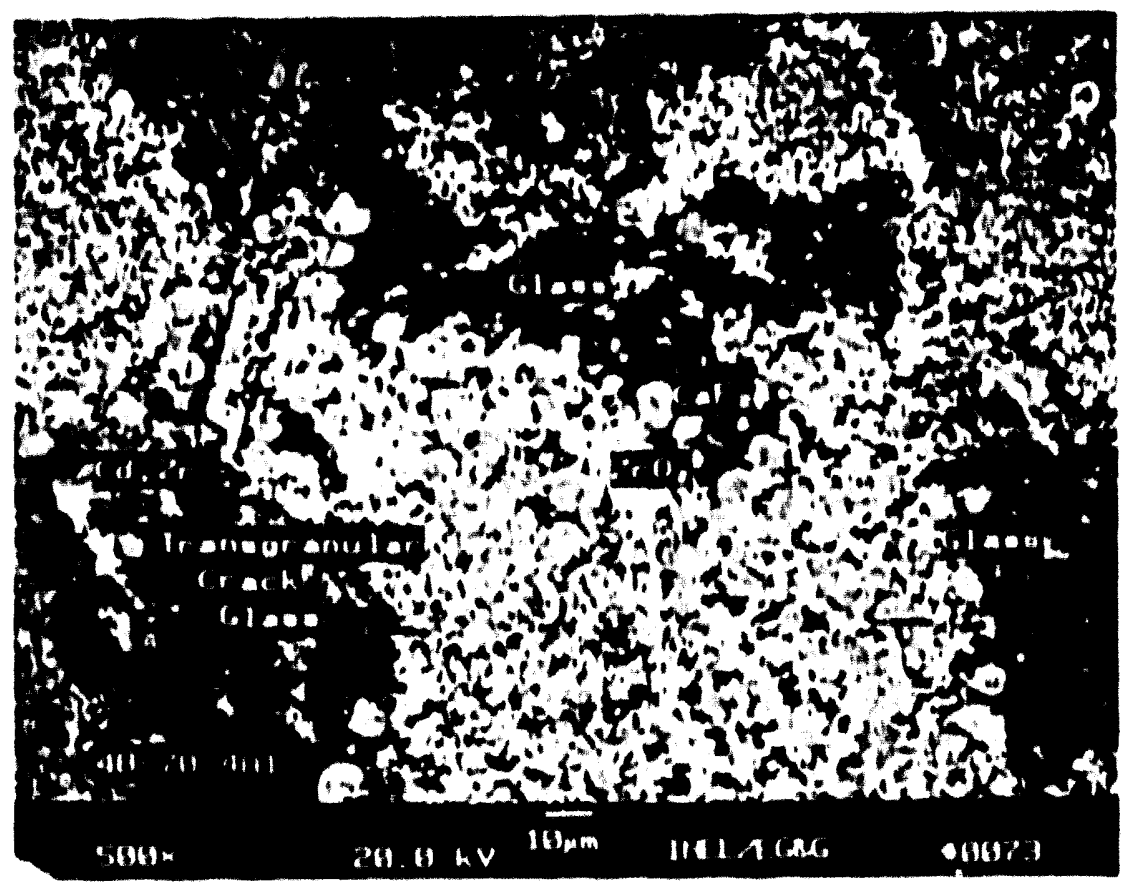

1()(d). 48 4AI-0Si-4hr Wasle form, s(X)X

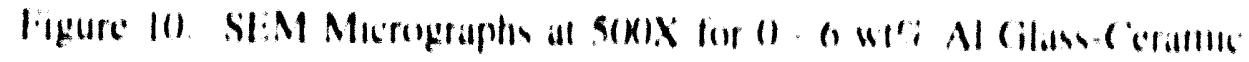

Wiste Forms 


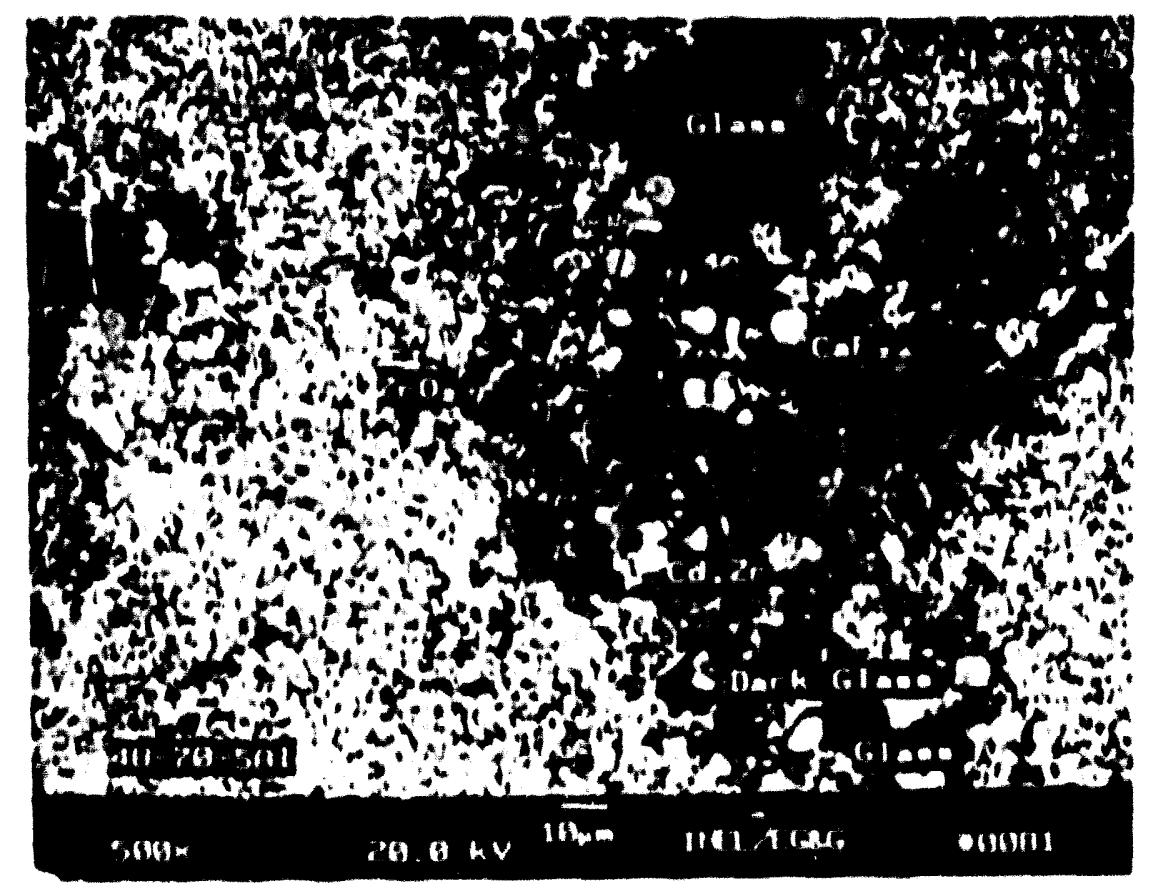

1(1)(C). 4X:5AI OSi - 4hr Waste form, $5(X) X$

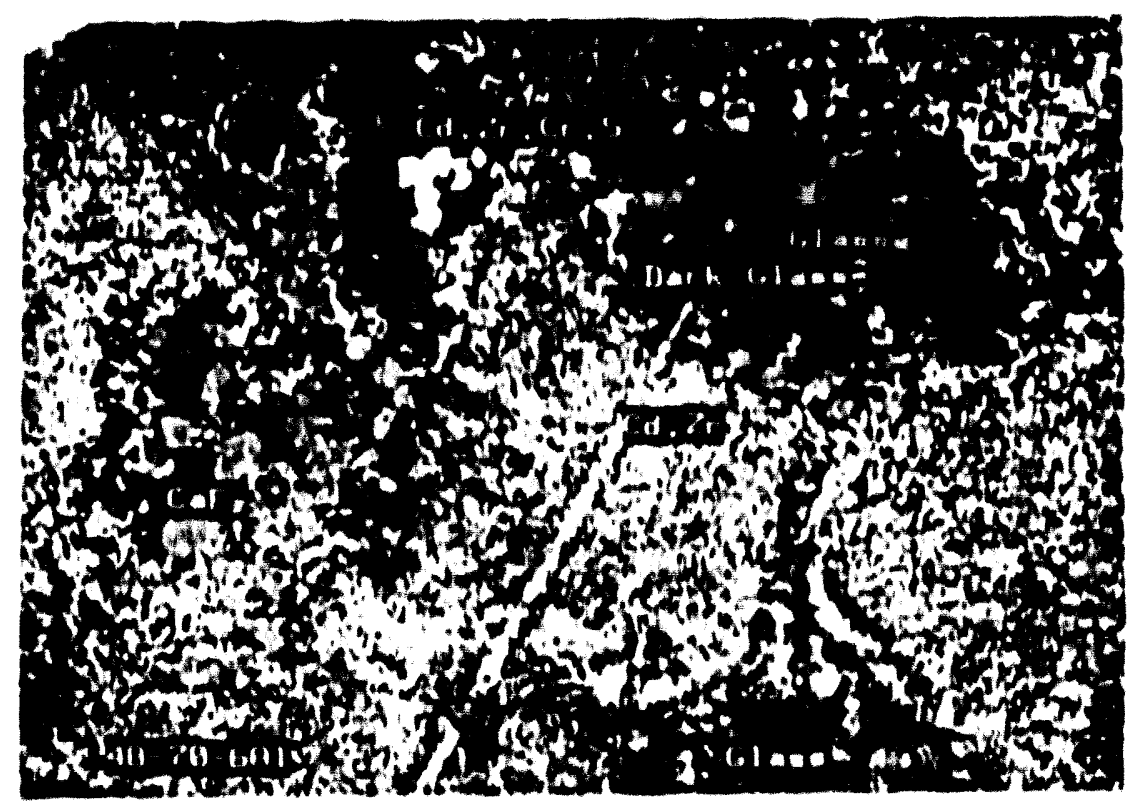

10(f) 48.6Al.(2)i-4hr Waste Form, s(x)X

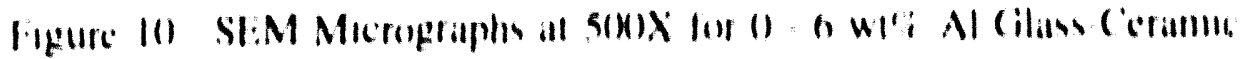
Wisle Iurms 
The SEM/Prohe micrographs for 0 and $3-5 \mathrm{wI} \% \mathrm{Si}$ waste forms (48-2AI-()Si and 48 2Al-3Si-4hr to 48-2Al-5Si-4hr) shown in Figure $11(\mathrm{al}-\mathrm{f})$ appear $\mathrm{to}$ be devoid of large crystalline grains in the glassy dark region. indicuting relatively high viscosity of the glass phase compared to 0 wI\% Al waste form, see Fig. 9(11), where large crystals are seen in the glass phase. Suble changes in microstructure as Si content increased from 3-5 wi\% are not reudily seen in microgruphs in Figure $11(11-f)$.

The SEM/Probe micrographs shown in Figures $12(a-f)$ for the 2 wit Al waste forms HIPed at souk times of 4. 8. 16 and 24 hours appeur to be essentially similar. It appears that the gluss in these waste forms is of a high lemperature (high viseosity) glass phase which is consistent with the meusured low TMLRs and normalized elemental leach rates. The higher viscosity was inferred from the microstructure (see Figures 12 (il-b)) where crystals were not seen in the glass islands. The observation of similar crystal growth (see Figures $12(e-h)$ ) between the waste forms that were HIPed for $4-24$ hours suggests that the 2 wi\% Al waste form must have reuched near the equilibrium composition at ahout 4 hours of the HIP souk lime. The SEM backsculterd electron micrographs for 4 hour ground (44) $\mu \mathrm{m}$ MMD) and the unground (215 $\mu \mathrm{m}$ MMD) sumples ure compured in Figure 1.3 (a,h). Concentric rings of $\mathrm{ZrO}_{2}$, and $\mathrm{CaF}_{2}$ crystallites in the glassy matrix are seen in the unground culcine waste forms.

Microstructures in the gluss phase Using TEM with the associuted EDS/WDS and selected area diffraction were examined. The TEM micrographs are shown in Figures 14.17. In Figure if a zirconia particle with the characteristic tetrugonul/cubic layered structure is shown for 48-2Al-0Si-4hr sample. A chromium needle and a cadmium sulphide particle in the glass phase are seen for $48-2 \mathrm{Al}-0 \mathrm{Si}-24 \mathrm{hr}$ sample in Figures 15, and 16, respectively. The characteristic motlling of the calcium fluoride phase is apparent in Figure $17,1 \mathrm{~cm}=0.036$ Hm) for 48-2Al-0Si-24hr sumple. In general, the glass phase appears to be clean and no apparent phase separation was noticed. 


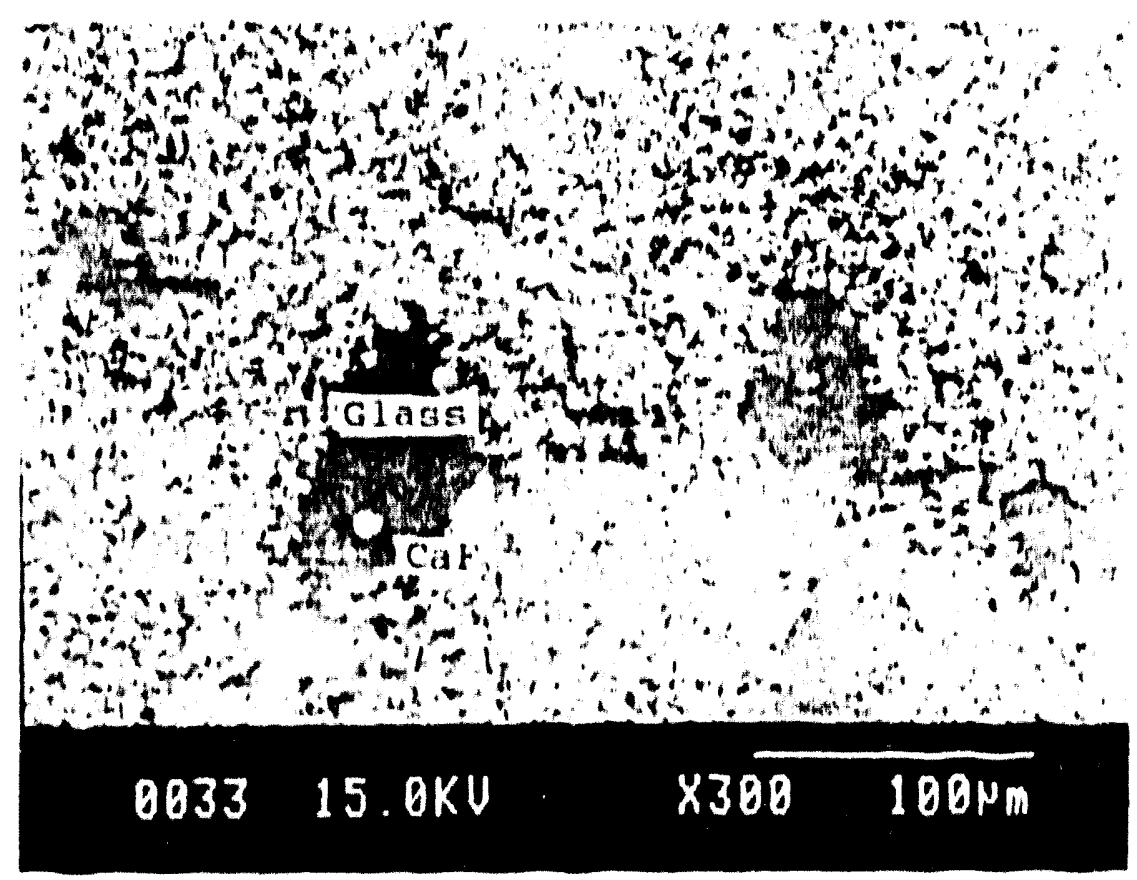

II(a), 48-2AI-0Si 4 hr Waste Form, 30()X

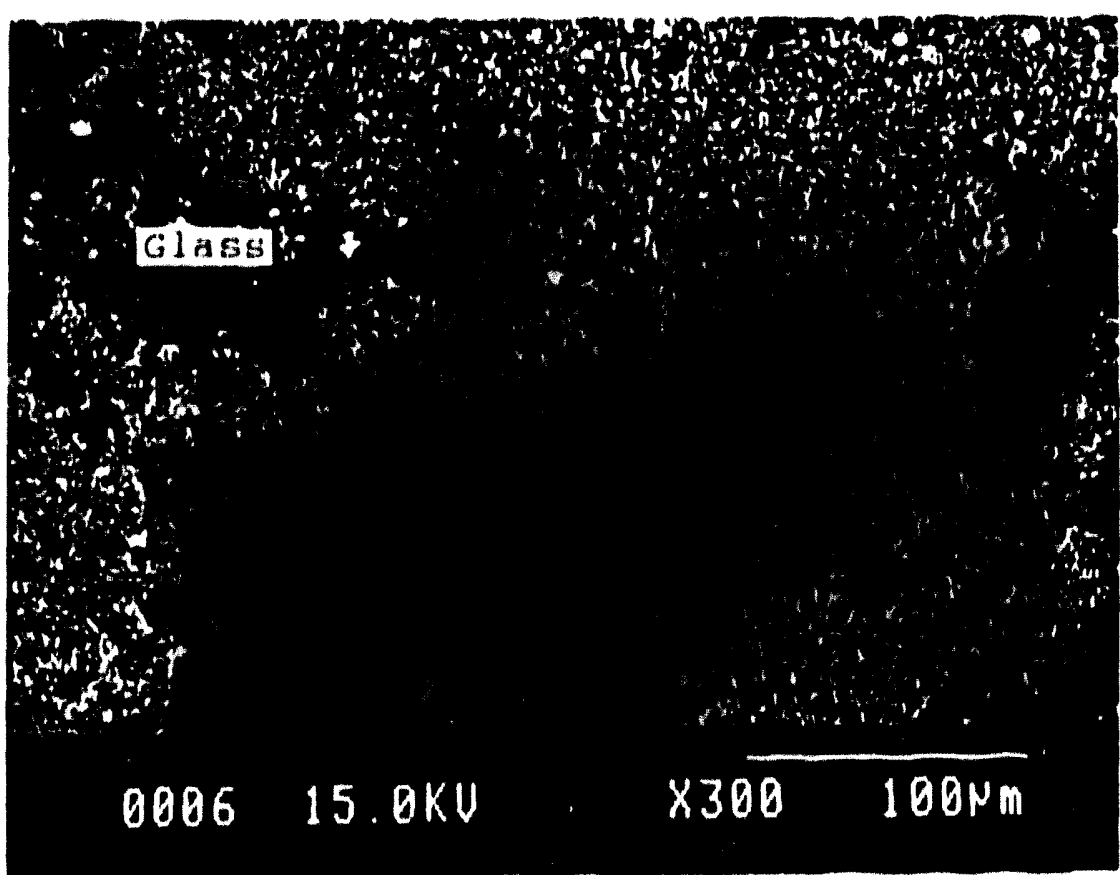

11(b), 48-2Al-3S1-4hr Waste Form, 3(X)X

Figure 11. Microprobe Micrographs at 300$) \times$ for 2 wi\% Al, 0.5 wi\% Si Gilass-Ceramic Waste Forms 


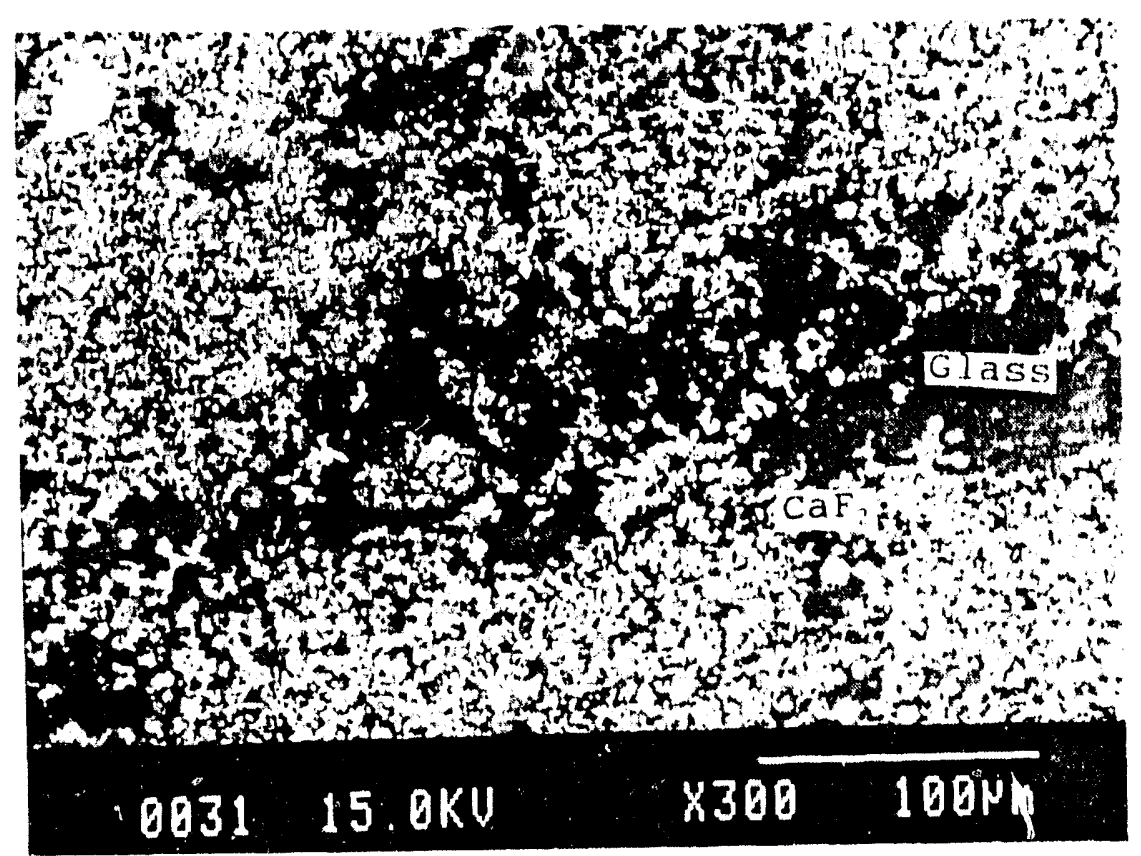

11 (c). 48-2Al-4Si-4hr Waste Form, $300 \mathrm{X}$

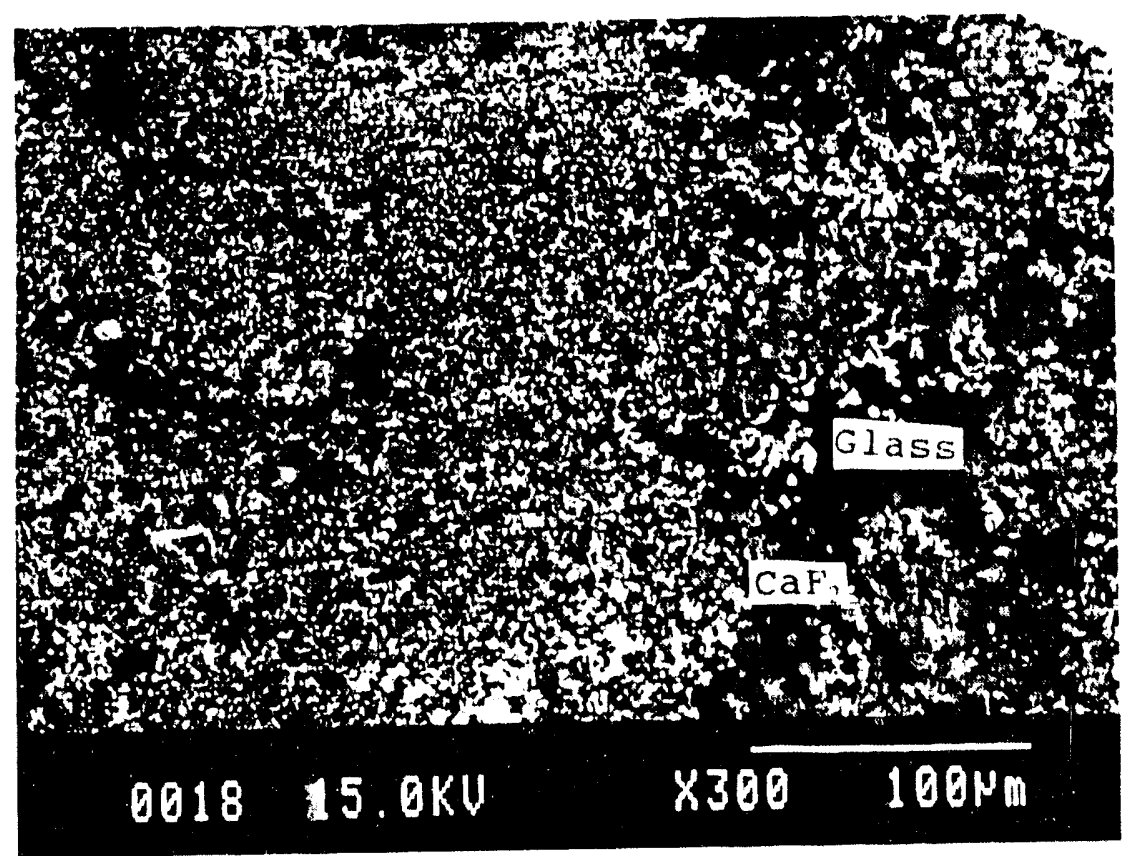

II(d). 48-2Al-5Si-4hr Waste Form, 300X

Figure 11. Microprobe Micrographs at $300 \mathrm{X}$ for 2 wt \% Al, 0-5 wt \% Si Glass-Ceramic Waste Forms 


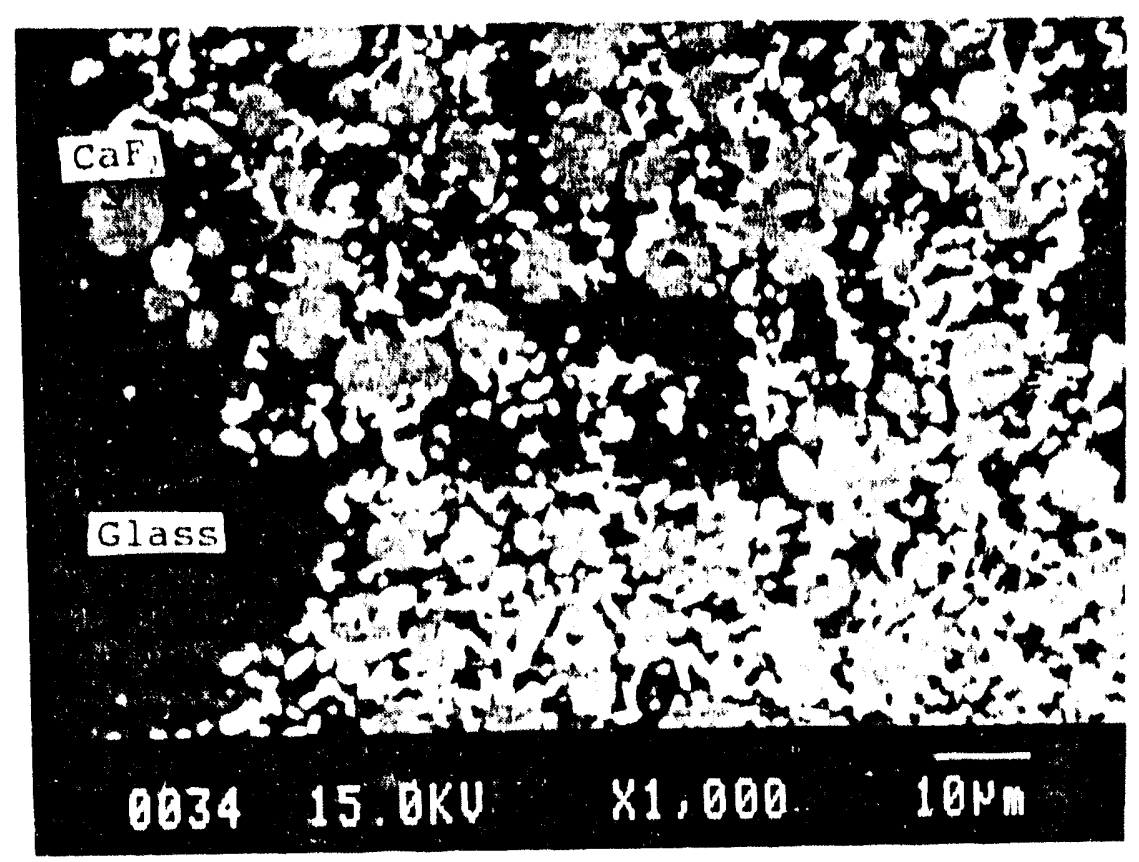

11(e). 48-2Al-0Si-4hr Waste Form, 1000X

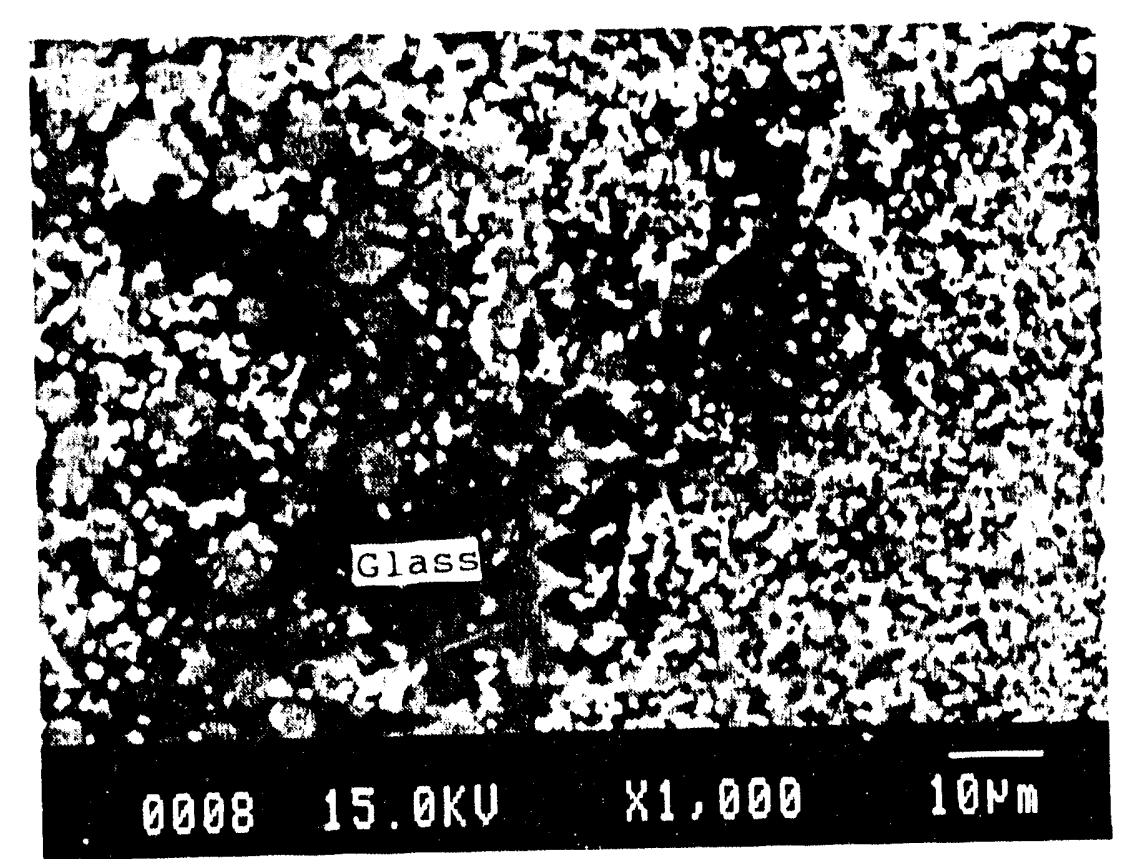

$11(f) .48-2 \mathrm{Al}-3 \mathrm{Si}-4 \mathrm{hr}$ Waste Form, 1000X

Figure 11. Microprobe Micrographs at $1000 \mathrm{X}$ for 2 wt $\%$ Al, 0-5 wt \% Si Glass-Ceramic Waste Forms 


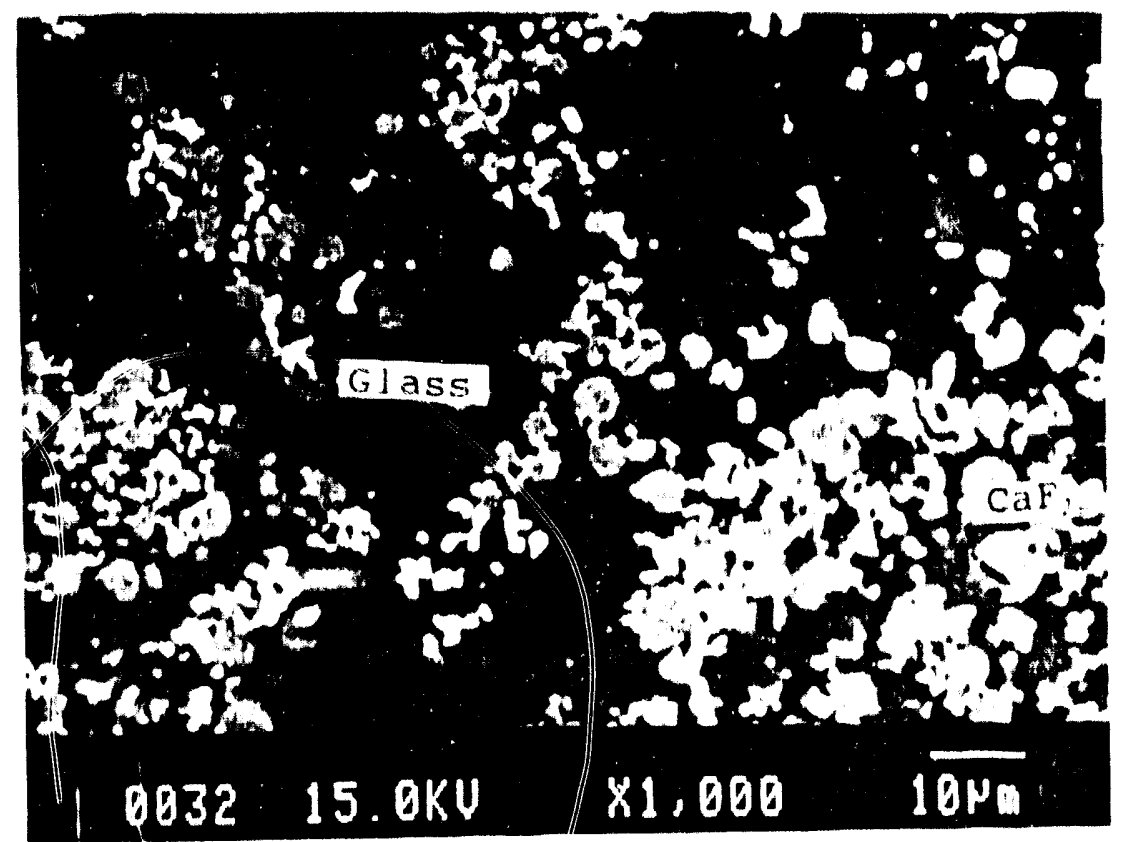

II(g). 48-2Al-4Si-4hr Waste Form, $1000 \mathrm{X}$

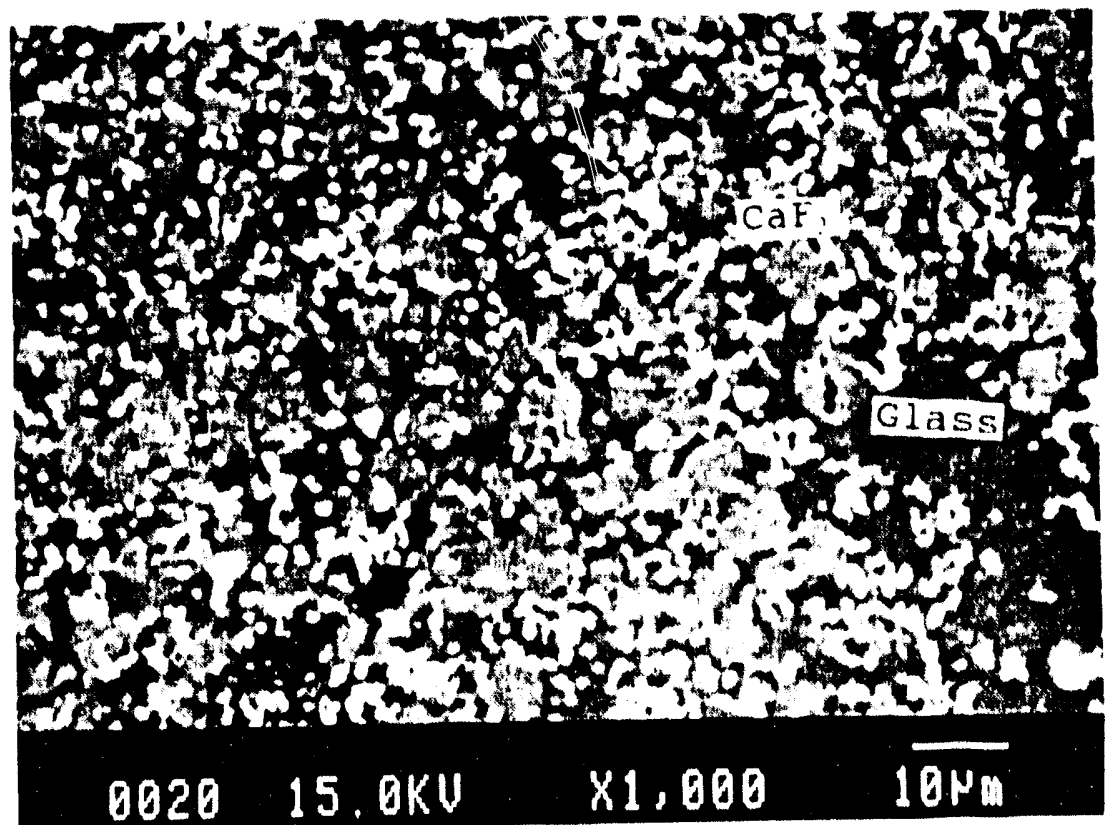

11(h). 48-2Al-5Si-4hr Waste Form, 1000X

Figure 11. Microprobe Micrographs at $1000 \mathrm{X}$ for $2 \mathrm{wt} \% \mathrm{Al}, 0-5 \mathrm{wt} \%$ Si Glass-Ceramic Waste Forms 


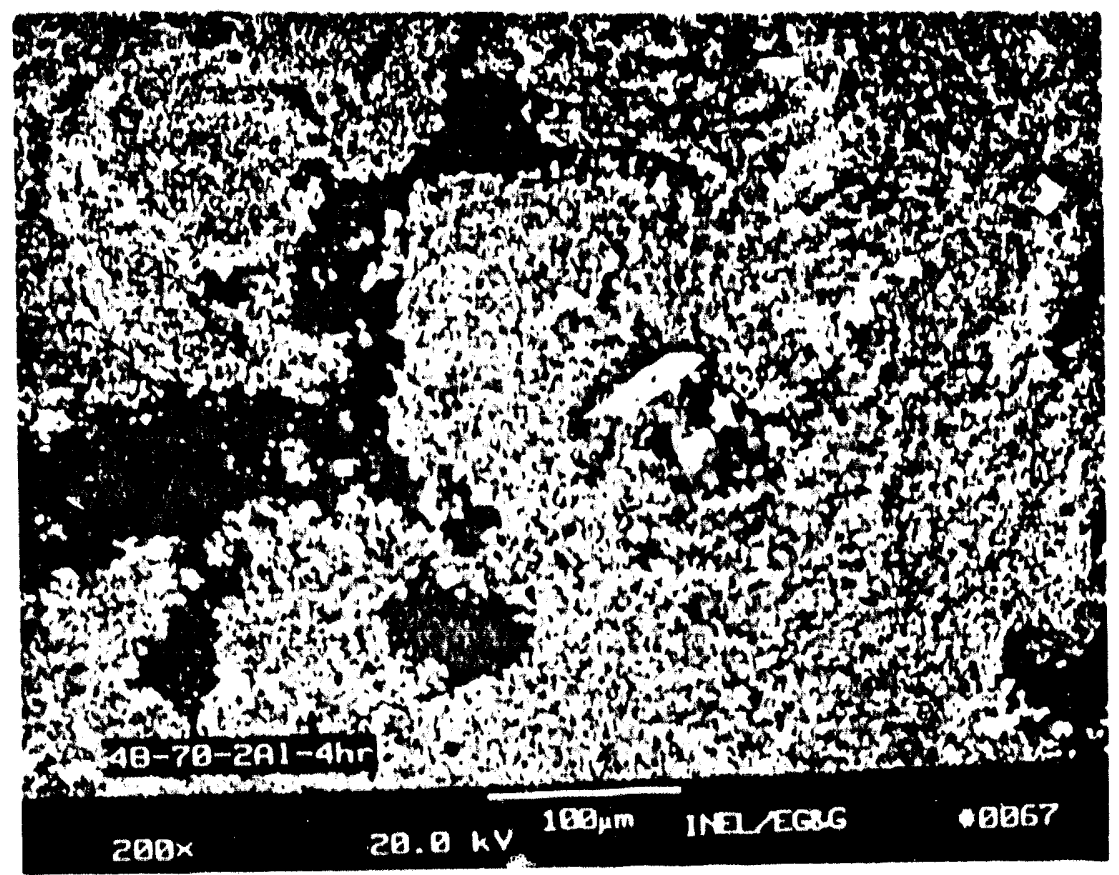

12(a). 48 2A1-0Si-4hr Waste Form, 200X

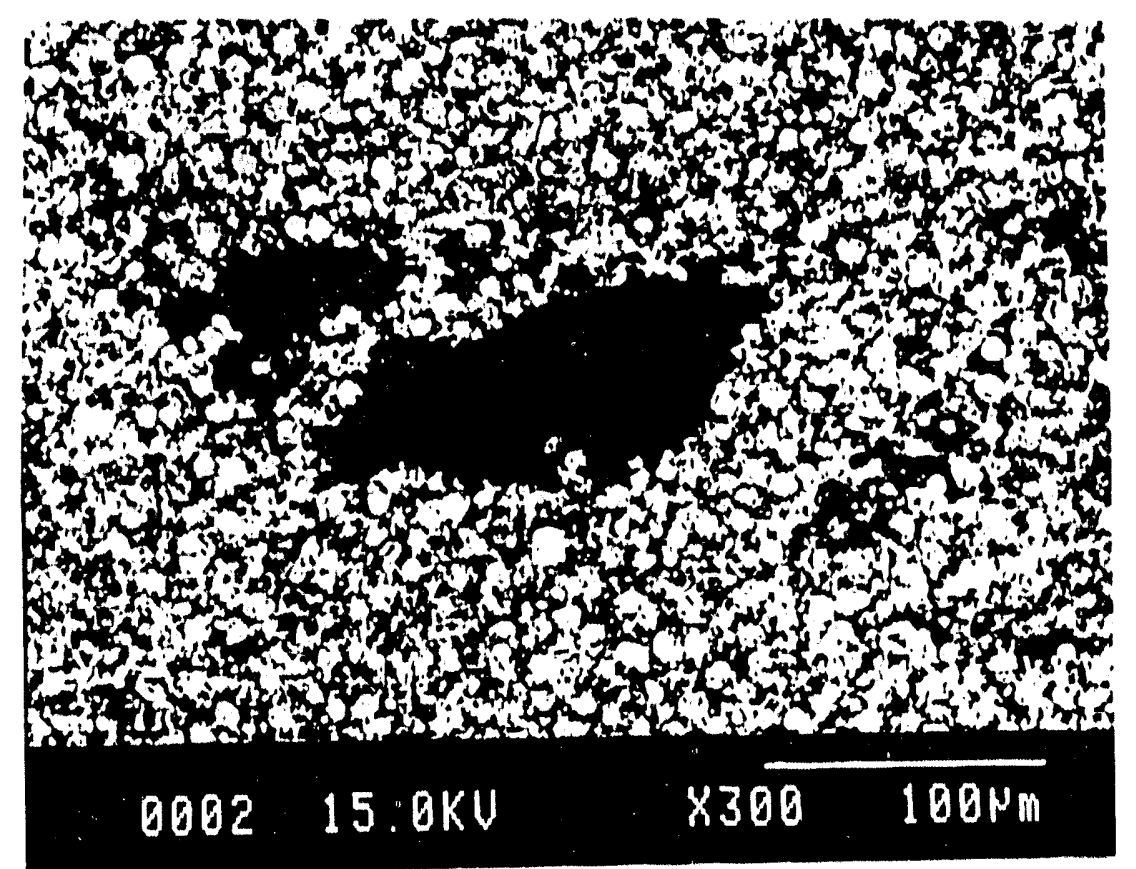

12(b). 48-2Al-0Si.8hr Waste Form, 300X

Figure 12. SEM/Probe Micrographs at 200-300X for 2 wt\% Al Glass-Ceramic Waste Forms HIPed for 4-24 Hours. 


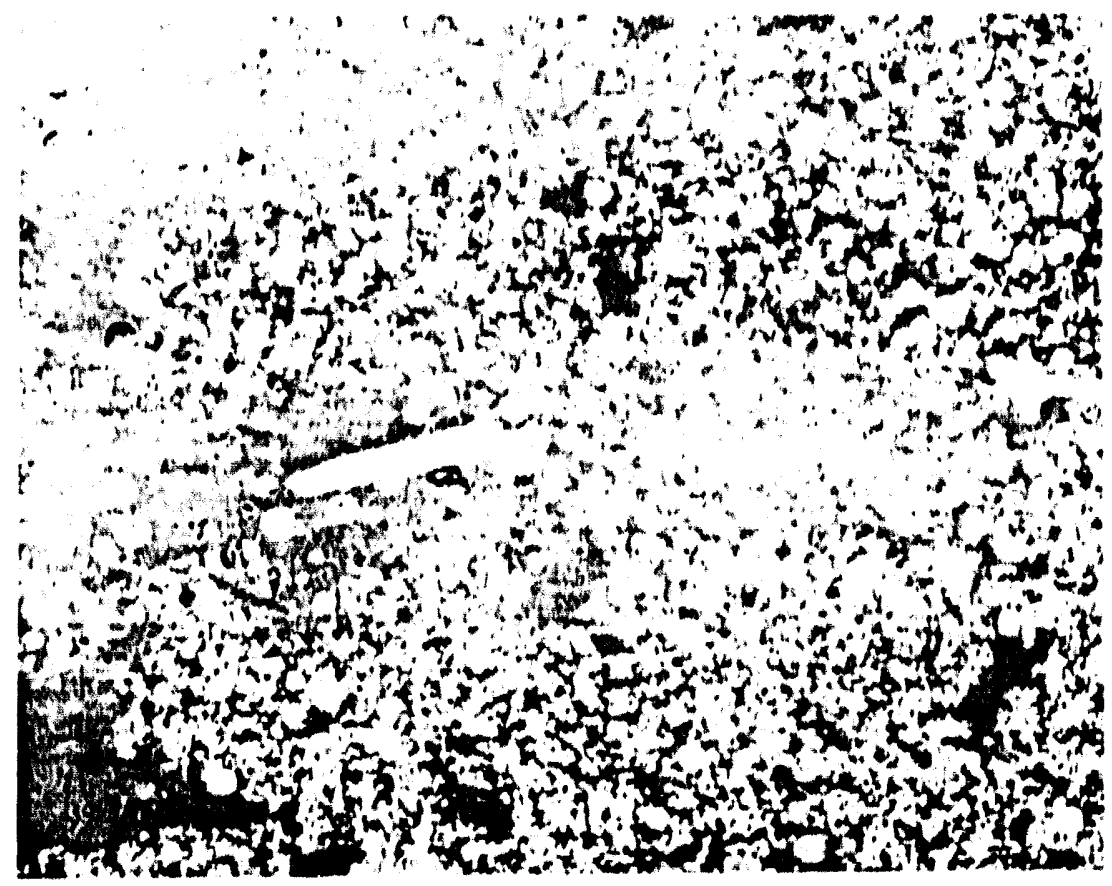

12(c). 48-2Al-0Si-16hr Waste Form, 300X

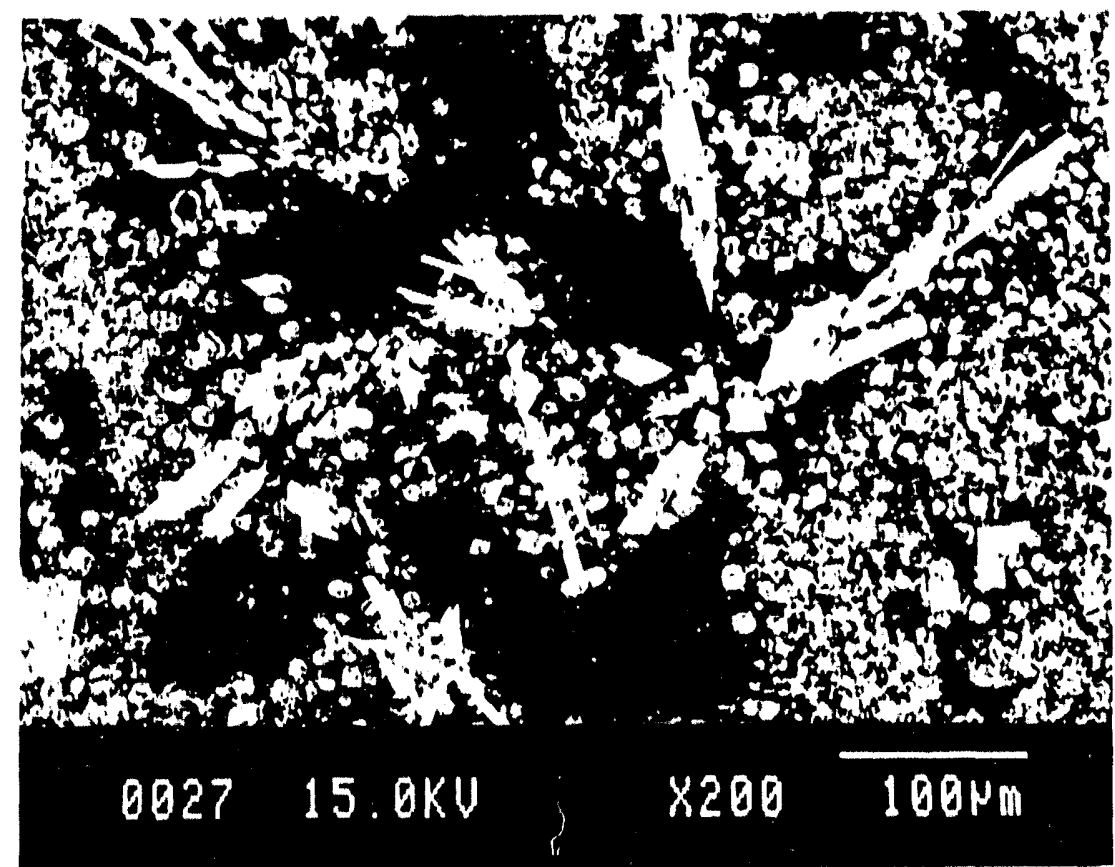

12(d). 48-2Al-0Si-24hr Waste Form, 200X

Figure 12. SEM/Probe Micrographs at 200-300X for 2 wt \% Al Glass-Ceramic Waste Forms HIPed for 4-24 Hours. 


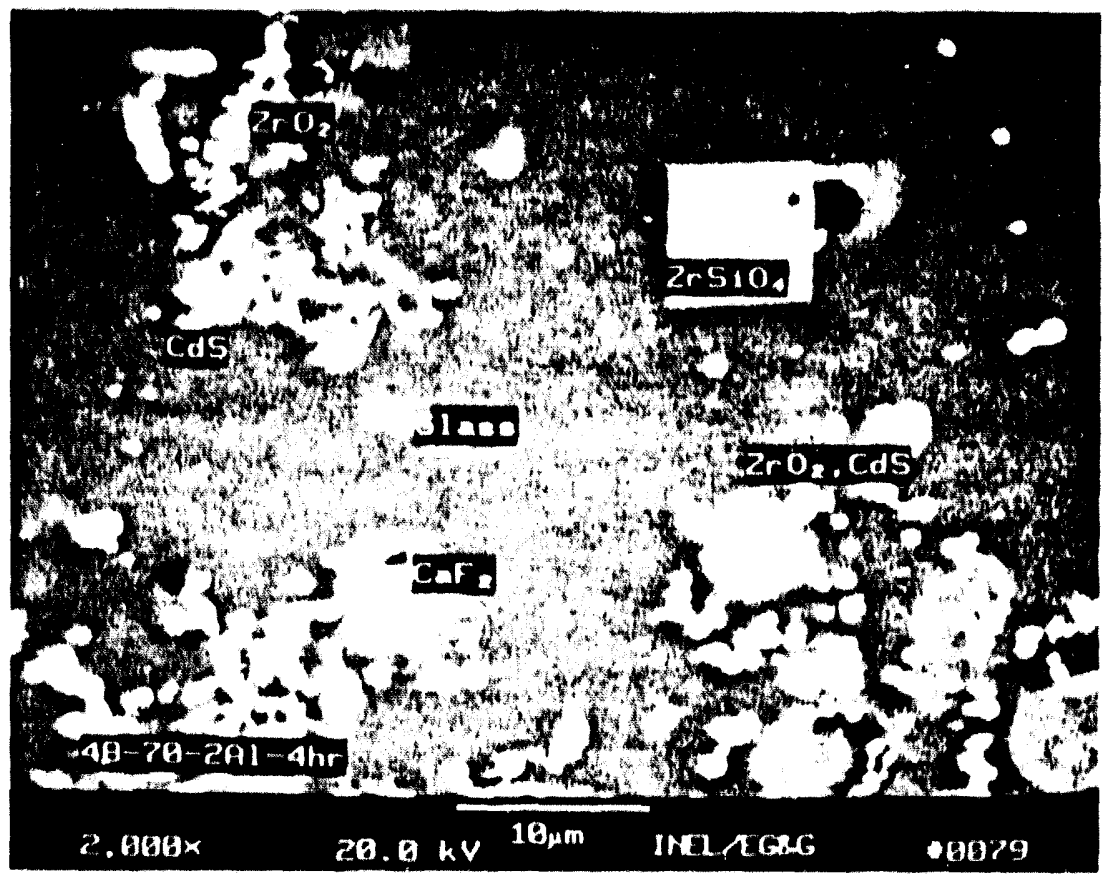

12(c). 48-2Al-0Si-4hr Waste Form, 2000XX

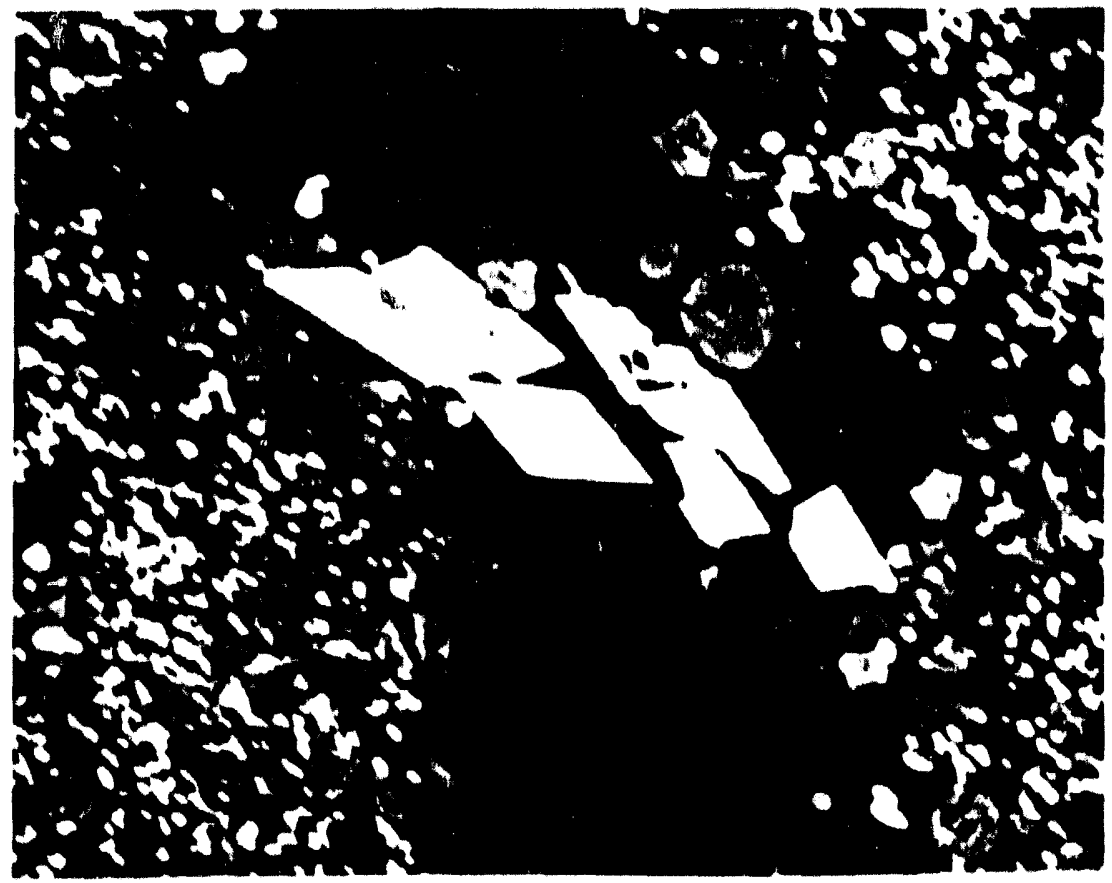

12(1). 48.2Al-0Si-8hr Waste Form, 1000X

Figure 12. SEM/Probe Micrographs at $10(0)-2(0)(0) \times$ for 2 wt $\%$ Al Glass-Ceramic Waste Forms HIPed for 4-24 Hours. 


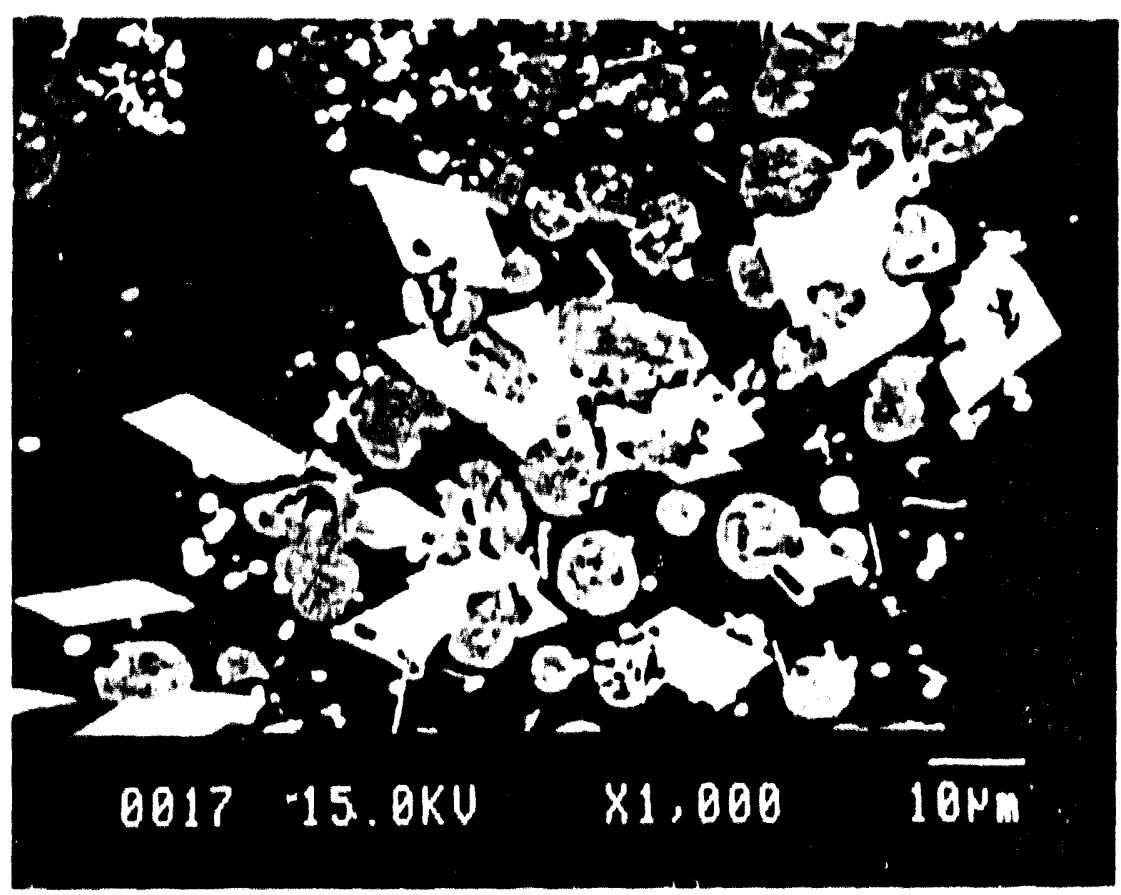

12(g). 48.2Al-0Si-16hr Waste Foim, I(X)(x)X

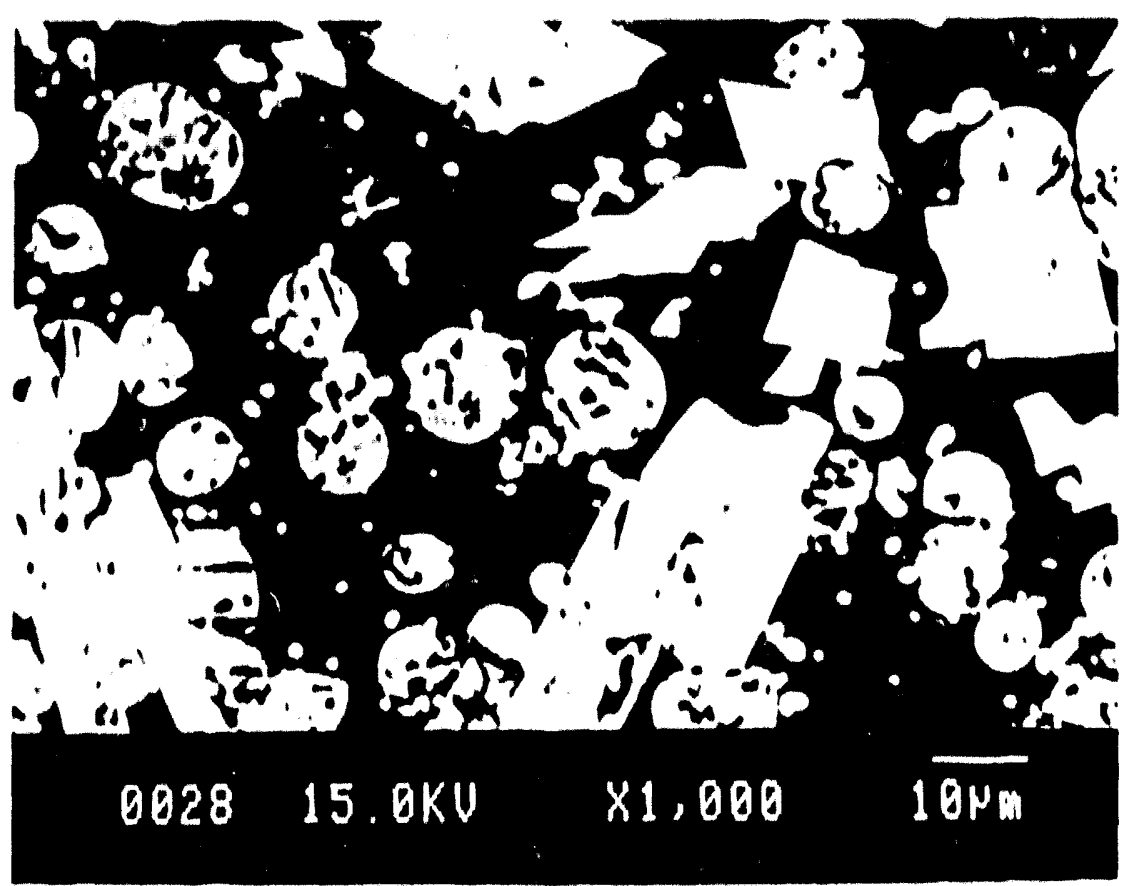

12(h). 48-2Al-0Si-24hr Waste Form, 10(0)X

Figure 12. Microprobe Micrographs at lo(0)X for 2 wt $\%$ Al Cilass-Ceramic Waste forms HIPed for 4.24 Hours. 


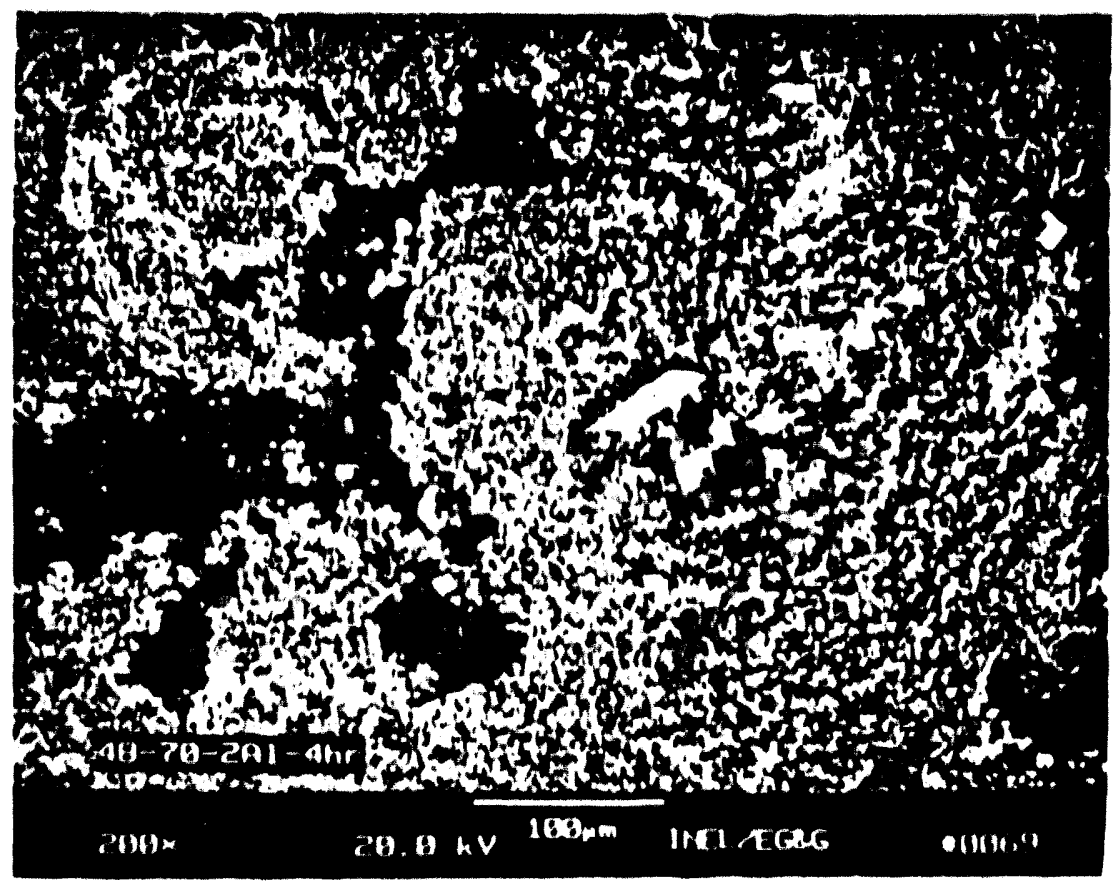

1.3(a), 48-2A1-0Si-4hr Waste Form, 2(X)X Ground Calcine ( -80 mesh)

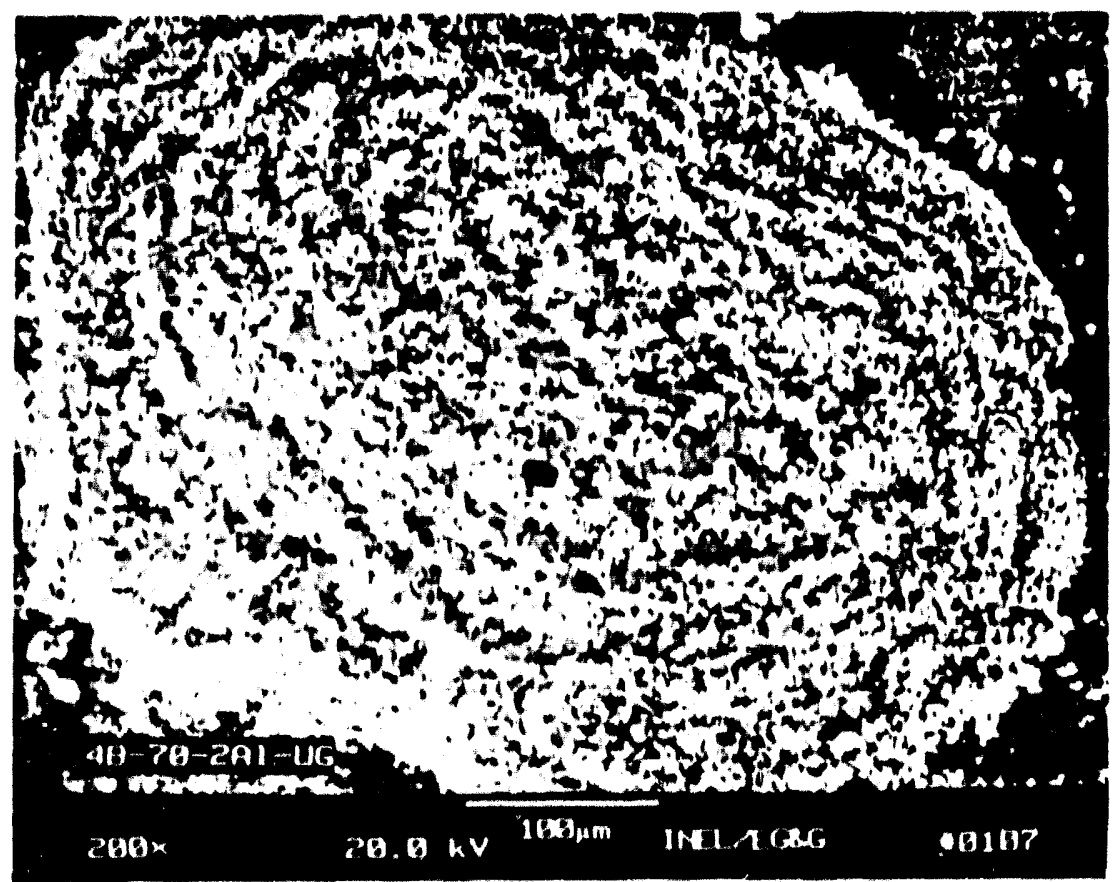

1.3(b). 48-2Al-0Si-4hr Waste Form, 200X Unground Calcine ( .30 mesh)

Figure 1.3. SEM Micrographs at 200X for 2 wt\% Al Glass-Ceramic Waste Forms Prepared with Ground and Unground Calcine. 


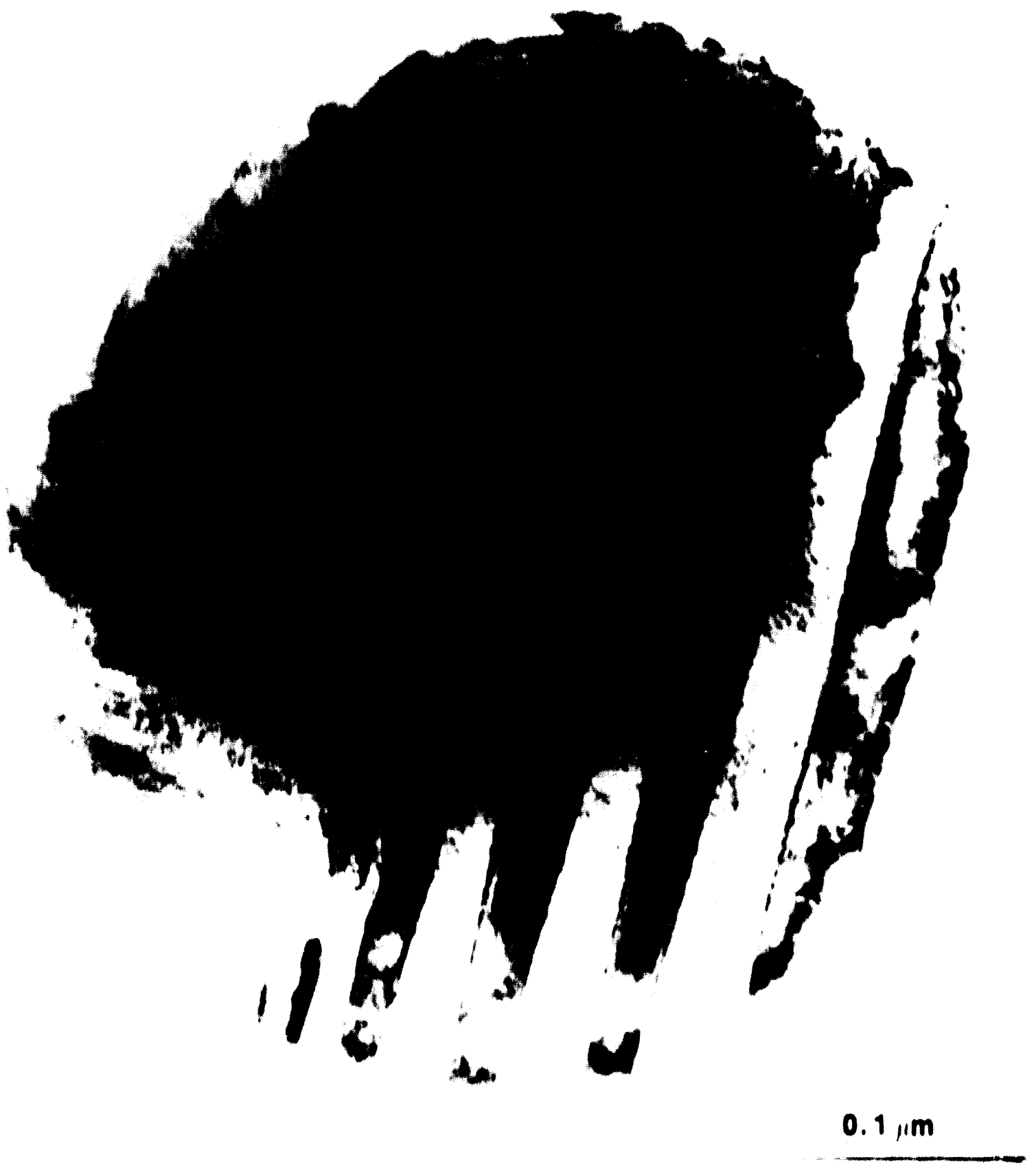

Figure 14. TEM Micrograph of Glass-Ceramic Waste Form Sample 48-2Al-()Si-4hr Showing a Zirconia Particle with the Characteristic Tetragonal/Cubic Layered Structure. 


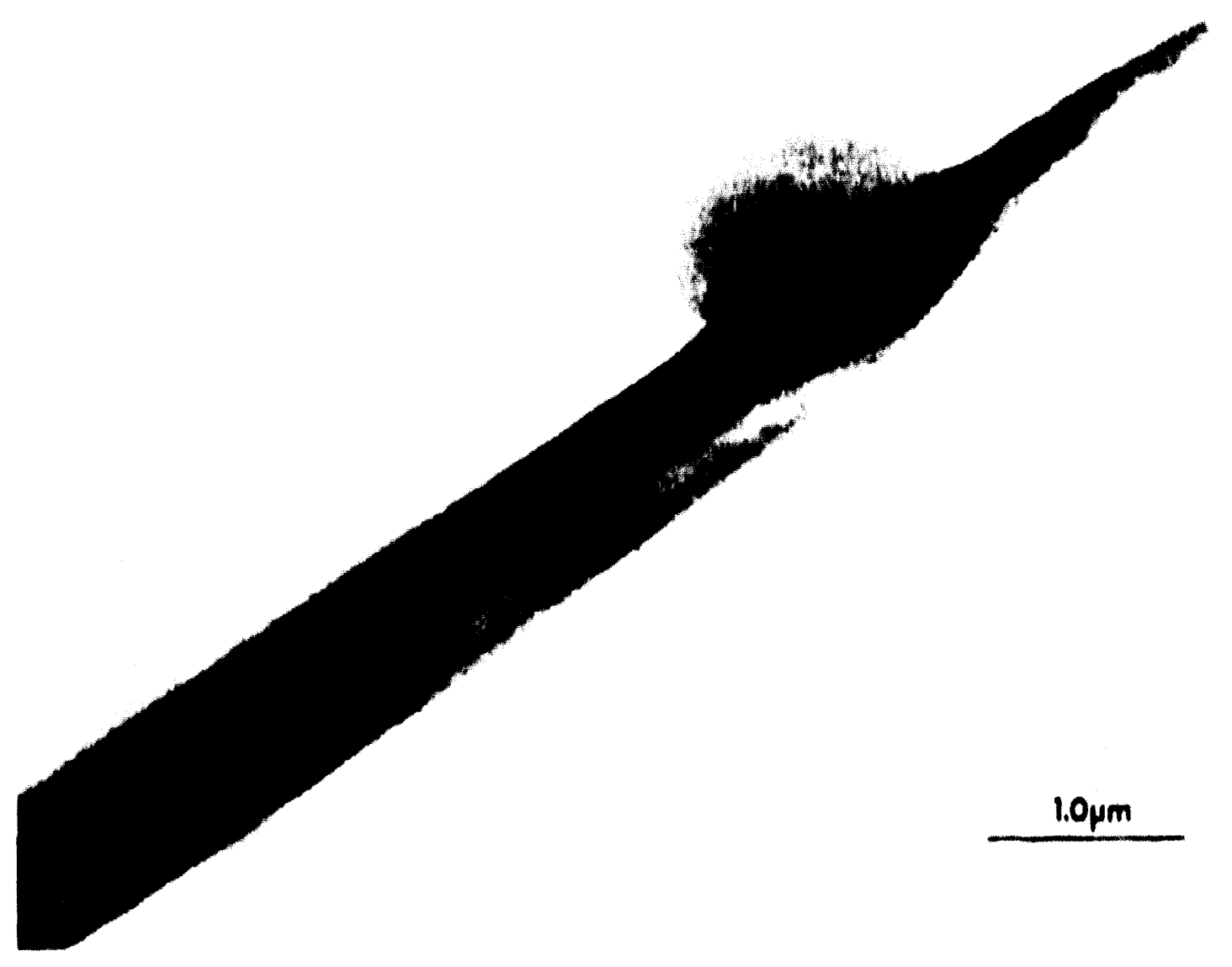

Figure 15. TEM Micrograph of Glass-Ceramic Waste Form Sample 48-2Al-0Si-4hr Showing a Chromium Needle in the Glass Phase. 


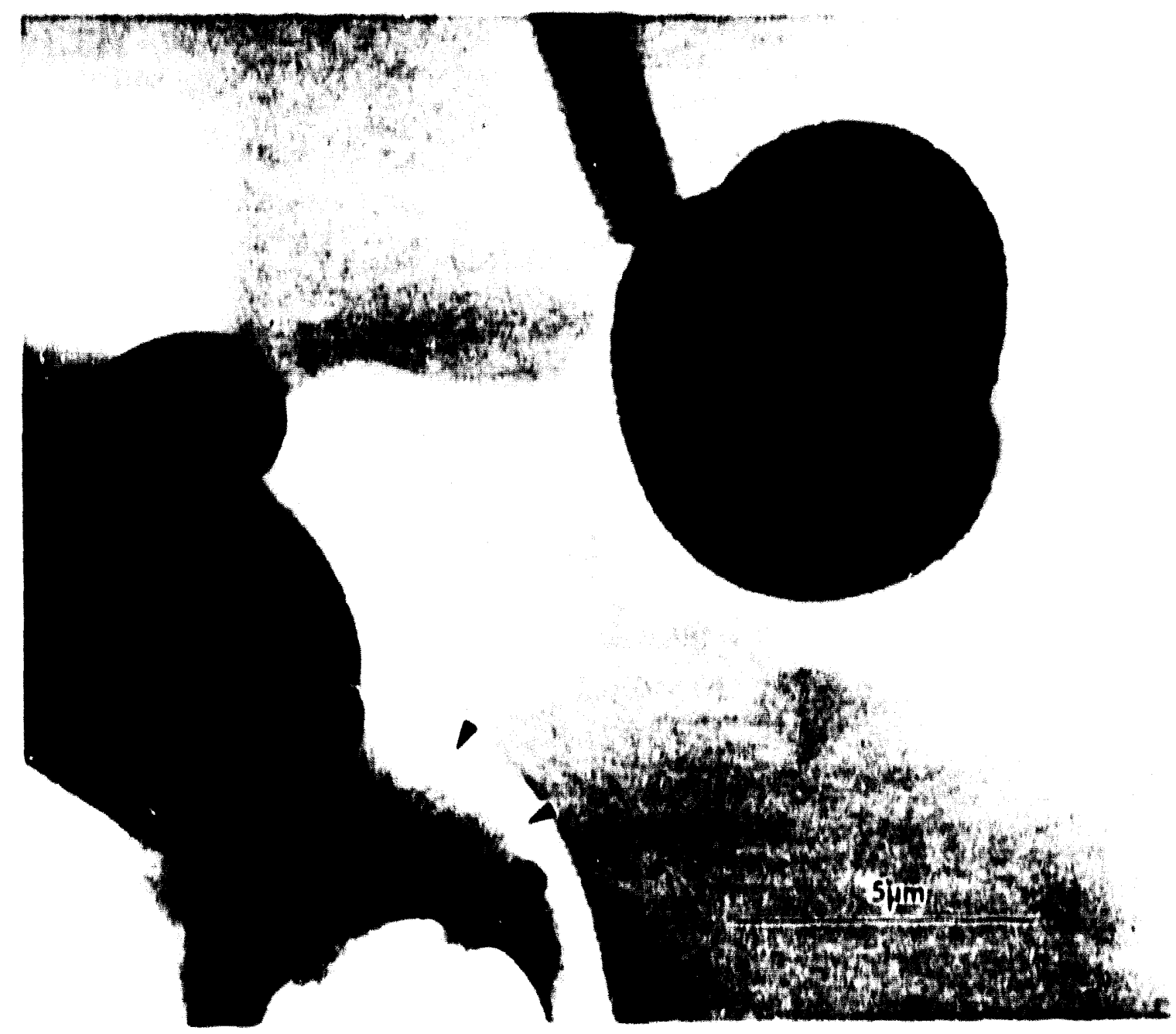

Figure 16. TEM Micrograph of Glass-Ceramic Waste Form Sample 48-2Al-0Si-4hr Showing a Cadmium Sulphide Particle in the Glass Phase. 


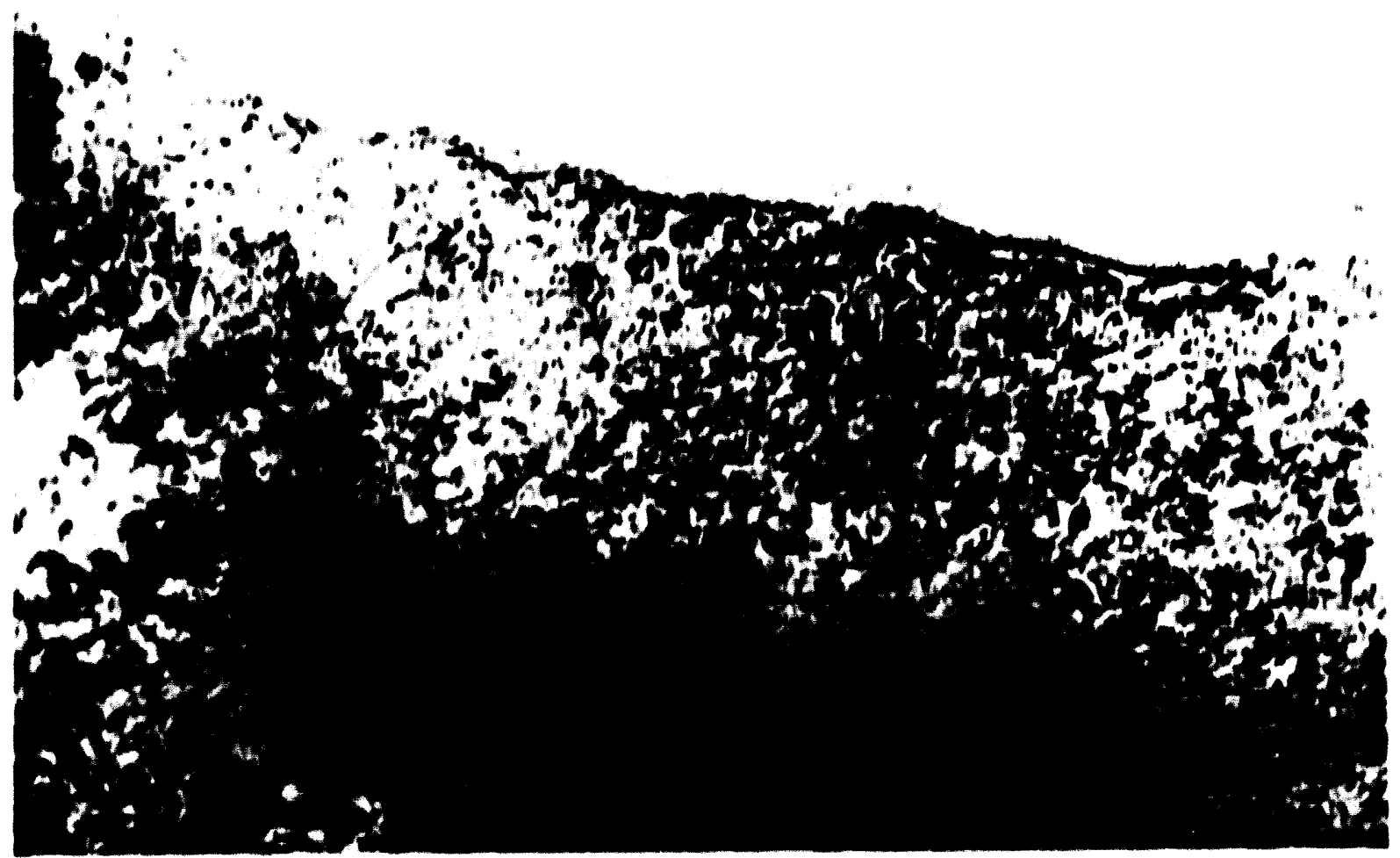

Figure 17. TEM Micrograph of Glass-Ceramic Waste Form Sumple 48-2Al-0Si-4hr Showing a Bright Field Image of Characteristic Mottling of Calcium Fluoride Phase. 


\section{SUMMARY AND CONCI.USIONS}

Glass-cerumic waste forms were synthesized hy HIPing a pre-compucled mixfure of 70

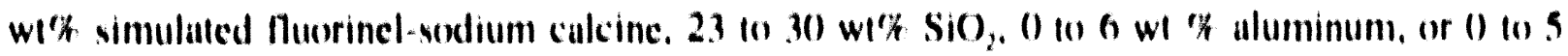

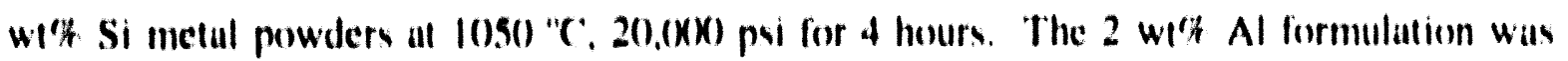
HIPed for 4, 8, 16 and 24 hours at the same lemperature and pressure. The effect of $\mathrm{Al}$ and Si reactants, the IIIP souk lime and the calcine initial particle size un wasle form churacteristics, densily, lotal and normalized elemental leach rales, and microstructure were investiguted.

The density of the waste furms increased from $3.03 .310 .10 \mathrm{~g} / \mathrm{cm}^{1}$ as the aluminum additive increased from ().6 wits, and there was no significant increase in densily as the silicon additive increased from 0105 with and 41024 hours. This is due 10 the increase in alumina in the glass phase for the () 10 o w1\% aluminum wasle forms. As the HIP time was increased from 4 to 24 hours for the 2 wit Al wasle form, the density remuined essentially constant suggesting that the waste form might have reached equilibrium composition at ahout 4 hours of Hilping.

The 14-day MCC.1 lobul mass loss rates and normalized elemental leach rates for Al. B. Ca. Cd. Cr, Cs, K, Na, Si, Sr and Zr are all less than $1 \mathrm{~g} / \mathrm{m}^{2}$. Jay for the $2 \mathrm{wt} \% \mathrm{Al}$ (4K. 2Al-()Si-4hr) and 3 wiY Si (4K-2Al-3Si-4hr) waste forms. However, the leach rates increased us the Al or the Si additive wI\% increased from 2106 wI\%. The low leach rales for these waste forms is expluined in terms of NBOs per tetruhedral network forming cations (Si + Al). The leach rates remained essentially constant for the 2 wis Al waste form that was IIIPed for $4,8,16$ and 24 hours. The leach rates increased us the calcine particle size increased. hul remuined less thun $1 \mathrm{~g} / \mathrm{min}^{\prime}$-day.

The lernary phase diagram for $\left(\mathrm{CuO}-\mathrm{Al}_{3} \mathrm{O}_{1}-\mathrm{SiO}\right)_{2}$ and the phase compatibility triangles (Silica-Anorthite-Alpha-Wollastonite and Silica-Anorthite-Mullite) were used to interpret the glass phase compositions. The glass compositions of the wasle lorms $(1) .3$ wis Al lie in the 
phase compatibility triangle for cristobalite $\left(\mathrm{SiO}_{2}\right)$, alpha-wollastonite $\left(\mathrm{CaO}_{2} \mathrm{SiO}_{2}\right)$ and unorthite $\left(\mathrm{CaO} . \mathrm{Al}_{2} \mathrm{O}_{1}, 2 \mathrm{SiO}_{2}\right)$ phases. The $4.6 \mathrm{wl} \% \mathrm{NI}$ waste form's glass composition lie in the phase computibility triangle for cristobalite $\left(\mathrm{SiO}_{2}\right)$, anorthite $\left(\mathrm{CaO}, \mathrm{Al}_{2} \mathrm{O}_{1}, 2 \mathrm{SiO}_{2}\right)$ and mullite $\left(3 \mathrm{Al}_{2} \mathrm{O}_{1}, 2 \mathrm{SiO}_{2}\right)$ phases. Similar trend is observed for (1).5 wi\% Si waste forms. The compositions of cristobalite $\left(\mathrm{SiO}_{2}\right)$, alpha-wollastonite $\left(\mathrm{CaO} . \mathrm{SiO}_{2}\right)$ and anorthite $\left(\mathrm{CaO}_{1} \mathrm{Al}_{2} \mathrm{O}_{1}, 2 \mathrm{SiO}_{2}\right)$ for 4.24 hour waste forms are similar. It appears that anorthite is a major component $(58$ wi $\%$ ) in the glass phase for 2 and 3 wt\% Al waste forms prepared by HIPing for 4 hours. Anorthite was nol observed in these samples. However, anorthite was detected by XRD in 16 and 24 hour sumples suggestin that the volume fraction that crystallized after 16-24 hours is significant for detection.

X-ray diffraction analysis for crystalline phases identified zirconia, calcium fluoride. and zircon as as major crystalline phases. Albite was identified in 4,8 and 16 hour waste form samples. Anorthite was indentified in 16 and 24 hour samples. Metallic Cd and CuS phases were identified with XRD, and the leach rates for Cd were low. None of the crystallinc phases exumined by SEM/EDS identified $\mathrm{Cr}$ containing crystals and the low $\mathrm{Cr}$ leach rites may be attributed to the durable glass phase.

Microstructures in the glass phase using TEM with the associuted EDS/WDS and selected aren diffraction were examined. Zirconia particles with the characteristic letragonal/cuhic layered structure, chromium needles and cadmium sulphide particles in the glass phase are seen for $48-2 \mathrm{Al}-(\mathrm{Si}-24 \mathrm{hr}$ sample The characteristic molling of the calcium 7luoride in glass phase is also seen for 48-2Al-0Si-24hr sumple. In general, the glass phase appears to be clean and no apparent phase separation was noticed.

Both the crystalline and glass phases are chemically durable in the 2 wt\% $\mathrm{Al}$ waste form. The measured elemental leach rates could be due to release from inter-phase houndaries, and uny other microcrystallites. It appears that the 2 wt\% Al waste form is a potential candidate for immobilization of the fluorinel-sodium calcine stored at the ICPP. 


\section{REFERENCES}

1. D. A. KNECHT and J. R. BERRETH, "Strategy Planning for the Long-Term Management of ICPP High-Level Radioactive Waste," Waste Management 88, pp. 837-843, September 1989.

2. R. S. BAKER et al, "Development of a Ceramic-Based Waste Form to Immobilize ICPP HLW," International Symposium on Radioactive Waste Management, ANS Meeting, September 14-18, 1986, Niagara Falls, NY.

3. R. S. BAKER and J. R. BERRETH, "A Glass-Ceramic Composition to Immobilize ICPP HLW," Proceedings of the 4th Int. Symp. Cer. Nucl. Waste Mgmt., Indianapolis, pp 13-22, 1989.

4. KRISHNA VINJAMURI, "Durability, Mechanical, and Thermal Properties of Experimental Glass-Ceramic Forms For Immobilizing ICPP High Level Waste," 1991 International High-Level Radioaciive Waste Management Conference, April 28-May 3, 1991, Las Vegas, Nevada.

5. KRISHNA VINJAMURI et. al., "Waste Form Development For Immobilization of High Level Waste Calcine at the Idaho Chemical Processing Plant," 1992 International High-Level Radioactive Waste Management Conference, April 12-16, 1992, Las Vegas, Nevada.

6. KRISHNA VINJAMURI, "Effect of Aluminum and Silicon Reactants and HIP Soak Time on Characteristics of Glass-Ceramic Waste Forms," Environmental and Waste Management Issues in the Ceramic Industry Symposium, 95th Annual American Ceramic Sociaty Meeting, Cincinnati, Ohio, April 18-22, 1993. 
7. 40 CFR Part 268, Federal Register/Vol. 57 No. 101, May 26, 1992, p 22046-22047.

8. J. R. BERRETH, "Basic CERCOMP Instructions for Use", Personal Communication, February 1990.

9. KRISHNA VINJAMURI, "A computer Program to Predict Glass-Phase Composition and Durability of Glass-Ceramic Form", to be published.

10. J. E. MENDEL (editor), Nuclear Waste Materials Handbook: Test Methods, DOE/TIC-11400, September 1983.

11. P. W. McMILLAN, Glass-Ceramics, Academy Press, 1964, pl4.

12. W. D. KINGERY, H. K. BOWEN and D. R. UHLMANN, Introduction to Ceramics, John Wiley \& Sons, New York, 1975.

13. E. F. OSBORN and A. MUAN, Phase Equilibrium Diagrams of Oxide Systems, Americal Ceramic Society, 1960, Plate 2.

14. L. H. VAN VLACK, Physical Ceramics for Engineers, Addison Wesley, 1964.

15. C. A. SORREL, Rocks and Minerals, Golden Press, New York, 1973. 

